\title{
INSTITUTIONS AND RELATIONSHIPS POLICY IN WESTERN LIBERAL DEMOCRACIES
}

\author{
BY \\ CHRISTOPHER DAVID NIMMO
}

\begin{abstract}
A thesis
submitted to the Victoria University of Wellington in fulfilment of the requirements for the degree of

Master of Arts

in Social Policy
\end{abstract}

Victoria University of Wellington

2015 



\begin{abstract}
This thesis explores the influence of institutions in the development of policies dealing with adult intimate relationships in New Zealand, Australia, and the United States between 1990 and 2014. Over this period, the social importance and acceptance of non"traditional" relationships has increased in New Zealand, Australia, and the United States. However, despite all three countries working from what Gauthier describes as a "noninterventionist" approach to family policy, relationships policies have developed in markedly different ways in each. I argue that divergent translations of similar social trends are the result of differences between the structures of decision-making and institutions of interest representation in each country, and of policy legacies that make particular policy avenues more readily accessible. Electoral systems, parliamentary procedures and party structures govern which interests are able to exercise power within legislatures, while other institutions such as courts, bureaucracies, and law commissions contribute to the policy-making process in different ways. Countries are less likely to move in a non-interventionist or pro-egalitarian relationships policy direction where candidate selection procedures allow religious conservatives to play a significant role in both major parties, but religious conservatives have had little success in reversing non-interventionist policy changes after the fact. Instead, protraditionalist policy changes are typically minor regulatory changes or expenditures that are vulnerable to budget pressures. Legal interests expressed through law commissions or justice bureaucracies have a key role in enabling transitions to non-interventionist policies, particularly in the treatment of non-marital relationships, although the treatment of these relationships in core government activities such as taxation and welfare may also contribute to decisions in this area.
\end{abstract}




\section{ACKNOWLEDGEMENTS}

I would like to acknowledge Dr Sandra Grey, a wonderfully supportive and knowledgeable supervisor, and a fine example of a public academic. I would also like to acknowledge the other academic staff (present and former) of Victoria University of Wellington who have (knowingly or not) contributed to my interest in this subject, particularly Dr Patricia Nickel, Dr Carol Harrington, Dr Rhonda Shaw, Professor Dr Wan Rafaei Abdul Rahman, Dr Kathy Stuart and Professor Kevin Dew. My thanks also go to the administration team at the School of Social and Cultural Studies for their support and encouragement, to the cleaners who make sure that the University is a pleasant place to work, to the library staff who have run off after books and journals for me, to the people who maintain the New Zealand and Australia Legal Information Institutes, and to all my postgraduate colleagues for their support.

Most of all I want to thank all my family for their encouragement of me over the course of my studies, particularly my mother Kathy, my father David, brother Jeremy, my Grandma Dalma and Avia Elizabeth. My Ave Gordon fits into a special category of his own, having both encouraged me with his wonderful smiles and contributed as Secretary of Justice to the legislation I studied. 


\section{CONTENTS}

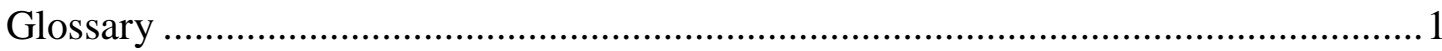

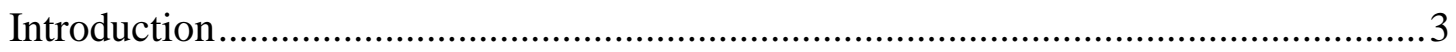

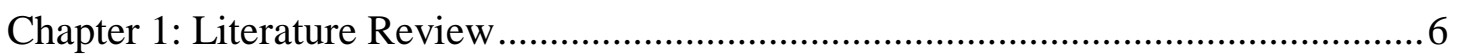

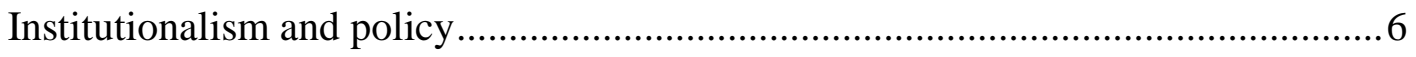

Comparative policy studies ..........................................................................

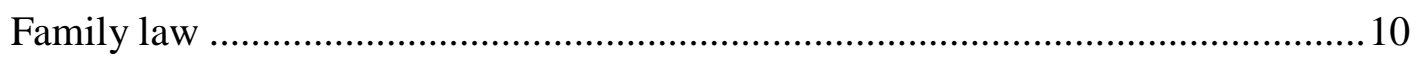

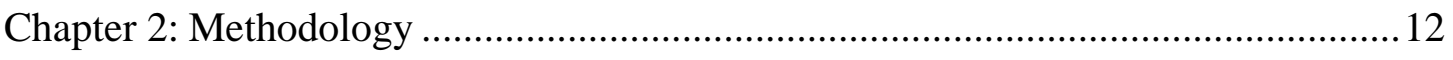

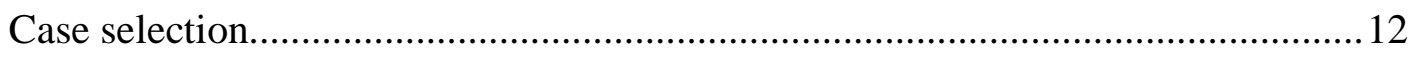

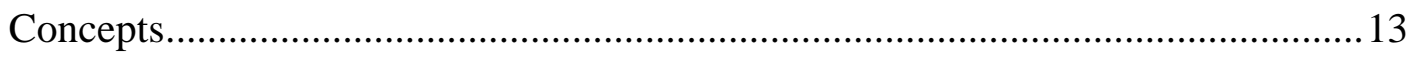

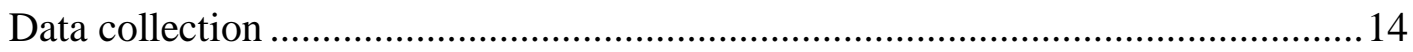

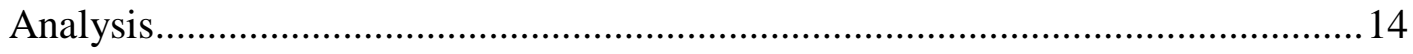

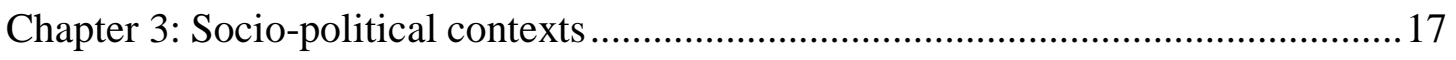

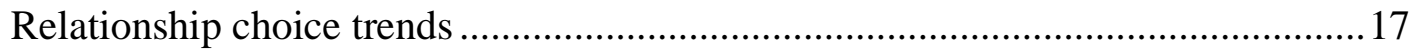

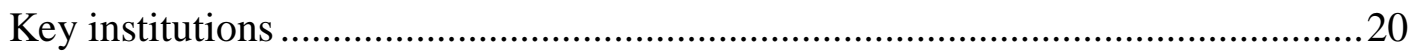

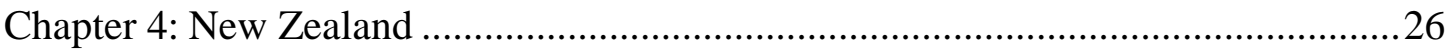

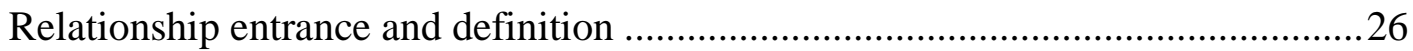

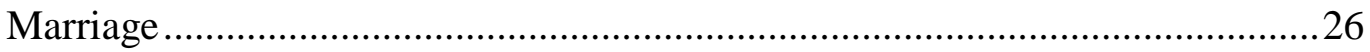

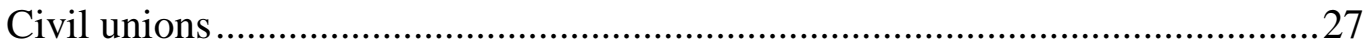

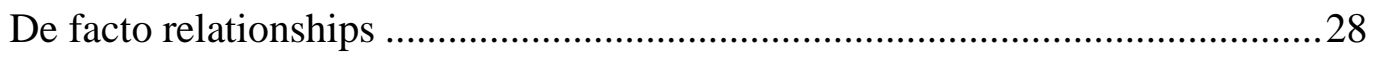

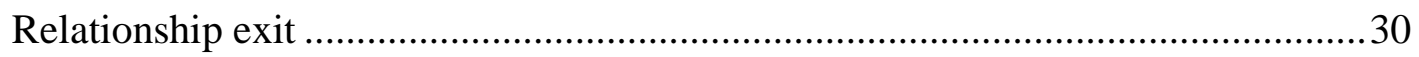

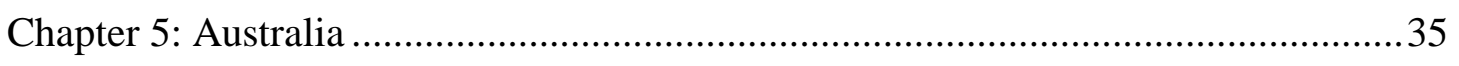

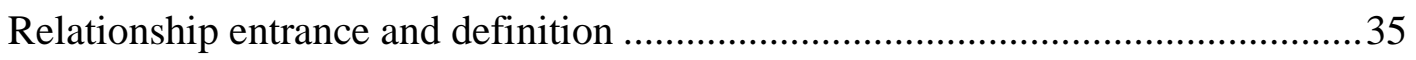

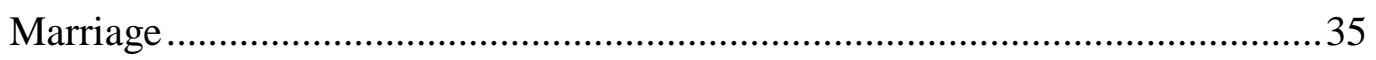

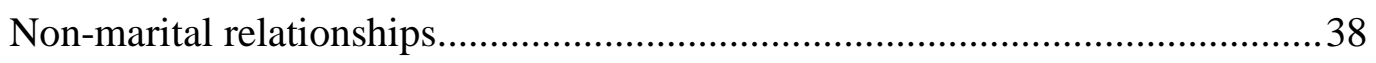


Relationship exit .42

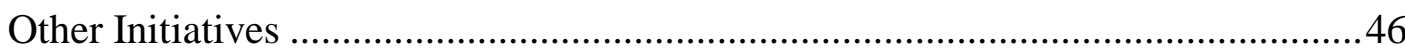

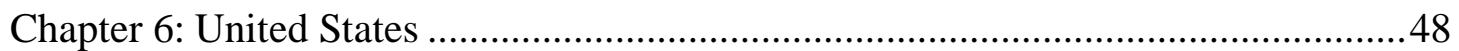

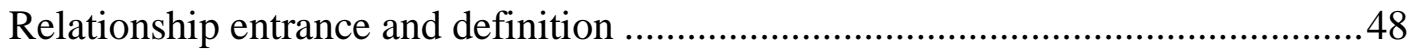

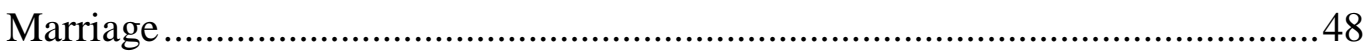

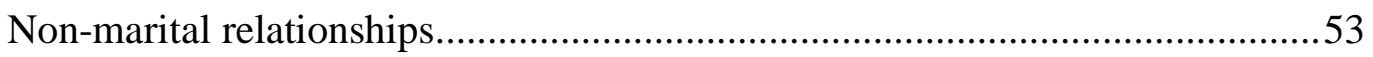

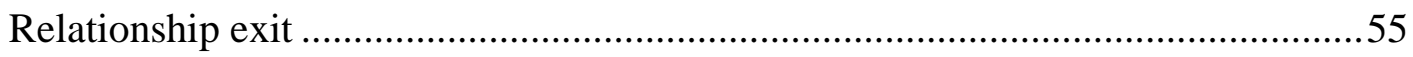

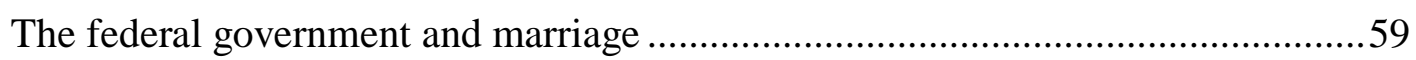

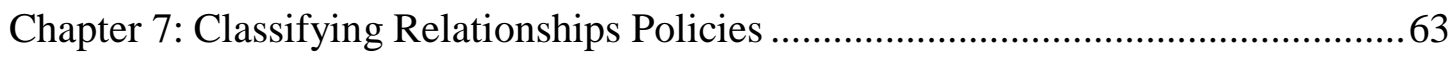

Translating family policy ideal-types to relationships policy ................................63

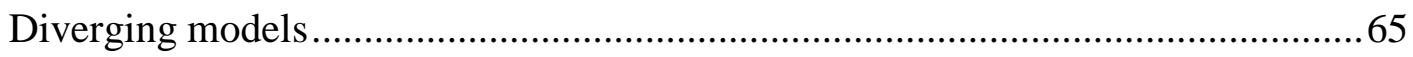

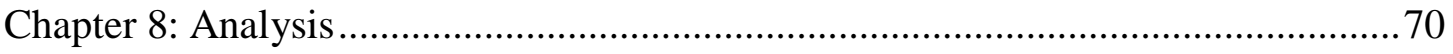

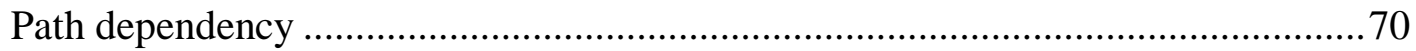

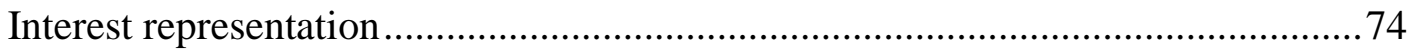

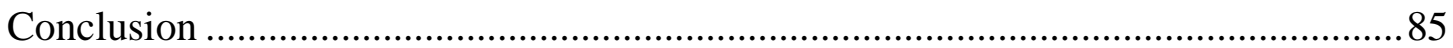

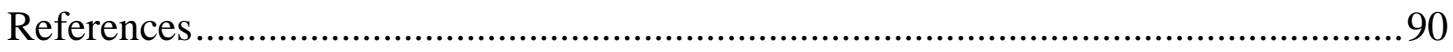

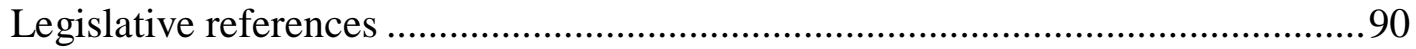

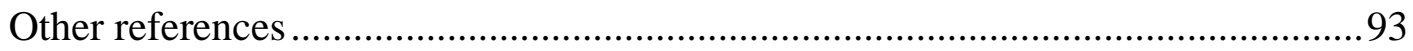

Figure 1: Absolute minimum ages of marriage in the United States ..........................51

Figure 2: Divorce regimes in the United States ..................................................56

Table: Characteristics of relationships policy models .........................64 


\section{GLOSSARY}

ABS: Australian Bureau of Statistics

ACL: Australian Christian Lobby

AFDC: Aid for Families of Dependent

Children

AIFS: Australian Institute of Family

Studies

ALP: Australian Labor Party

ALRC: Australian Law Reform

Commission\

AZRS: Arizona Revised Statutes

BDM Tasmania: Births, Deaths and

Marriages Tasmania

CAFC: California Family Code

CALRC: California Law Revision

Commission

CDC: Centers for Disease Control and

Prevention

CDR: Crude Divorce Rate (annual divorces per 1,000 population)

CMR: Crude Marriage Rate (annual marriages per 1,000 population)

CTLRC: Connecticut Law Revision Commission

CUA: Civil Union Act

CWfA: Concerned Women for America

DHS: Department of Human Services

DNC: Democratic National Committee
DOMA: Defence of Marriage Act

EGTRRA: Economic Growth and Tax

Relief Reconciliation Act

EITC: Earned Income Tax Credit

FLA: Family Law Act

FPA: Family Protection Act

FPP: First-past-the-post voting system

FTB-B: Family Tax Benefit B

GLAAD: (formerly) Gay \& Lesbian

Alliance Against Defamation

GLAD: Gay \& Lesbian Advocates and

Defenders

HIRS: Hawai'i Revised Statutes

HMRF: Healthy Marriage \& Responsible Fatherhood

IRS: Internal Revenue Service

LARS: Louisiana Revised Statutes

LPA: Liberal Party of Australia

MMP: mixed-member proportional voting system

MTRRA: Marriage Tax Relief

Reconciliation Act

NCHS: National Center for Health

Statistics

NCWNZ: National Council of Women of New Zealand 
NJLRC: New Jersey Law Revision

Commission

NPA: National Party of Australia

NSWLRC: New South Wales Law Reform

Commission

NWPC: National Women's Political

Caucus

NZEC: New Zealand Electoral

Commission

NZLC: New Zealand Law Commission

NZLP: New Zealand Labour Party

NZNP: New Zealand National Party

NZRL: New Zealand Rainbow Labour

OKS: Oklahoma Statutes
PRA: Property (Relationships) Act

PRAA: Property (Relationships)

Amendment Act

PRWORA: Personal Responsibility and Work Opportunity Reconciliation Act

QLDLRC: Queensland Law Reform

Commission

RNC: Republican National Committee

RSRB: Relationships (Statutory

References) Bill

TXFC: Texas Family Code

USBLS: United States Bureau of Labor

Statistics

USC: United States Code 


\section{INTRODUCTION}

Intimate relationships are crucial to human wellbeing on a number of levels. For individuals, intimate relationships represent emotional support or strain, religious or cultural fulfilment, sexual satisfaction or frustration, and financial security or anxiety. Intimate relationships knot individuals and families together with more or less firmness and provide a venue for the conception, nurturing and education of children. These "private" relationships have significant public consequences. The division of labour within intimate relationships has profound effects not only on the individuals involved, who may find accomplishment or oppression, but also on work environments and economies. The strength and character of intimate relationships may burden or unburden communities and governments.

Despite the importance of these intimate relationships, and despite the fact that governments intervene in them in a number of ways, comparative social policy theorists have not dealt with the question of why substantial differences exist between these interventions. My interest in the area originated from learning about Singapore's government dating agency (the Social Development Network) and wondering (from the perspective of somebody living in a liberal democracy) how such a policy could arise. I explored the development of marriage policies in Singapore and Malaysia in my Honours research, finding that their character was influenced by the ways in which political institutions (and particularly the structures of the dominant parties) shaped the interactions of and opportunities for different political interests (including ethnic, religious, and gender-based interests). In this thesis I develop that work by exploring how political and policy institutions have shaped the development of relationships policies (defined in Chapter 2) in New Zealand, Australia, and the United States of America between 1990 and 2014.

Exploring the development of relationships policies in liberal democracies is particularly interesting because of the assumption of privacy that surrounds intimate relationships in these countries. Questions of privacy and individual responsibility may arise around all kinds of policy; citizens may very well object to the government attempting to control how they spend their money, or how they raise their children, but government involvement in intimate relationships takes this to an extreme, raising the spectre of bureaucrats or politicians hiding under the bed. In regulating relationships and offering relationship services, policy-makers must navigate highly emotive privacy concerns, as well as related concerns about "social engineering". 
The institutional context in which these debates occur is important because it shapes which voices are privileged and which policy options are politically viable. The structures of political parties and electoral systems are important elements of this because relationships policy is an area in which right-wing and left-wing parties are not necessarily united. The balance of socially-conservative and socially-liberal representatives within major parties and the degree of independence afforded to these representatives by their leaders affect the nature and success of policy reforms. Electoral systems and party structures mediate this balance of interests and affect the degree of control that leaders may wield. Other institutional features such as constitutions, courts, and public participation processes also constrain or sway representatives' choices.

Over the course of this research I found it necessary to discuss the role of policies themselves as institutions that help to determine what kinds of policy change are possible. Even where broad patterns of relationships policy are similar across countries, the details of how policies are structured may affect their future direction. Policy changes may be difficult for both technical and ideological reasons. Relationships have implications for core activities such as welfare and taxation, so policy-makers usually avoid making changes to the treatment of relationships that could disrupt these activities. Policy-makers may be equally cautious about changing the treatment of relationships because of public suspicions about government intruding on individual, private relationships or the social institutions that surround these relationships. At the same time, however, existing policies may facilitate certain changes by providing concepts for policy-makers to use.

My first chapter discusses the available literature on political institutional influences on policy-making, the development of comparative social policy (and the gaps in the policy areas it deals with), and family law scholars' assessments of the development of relationships policy. My second chapter explains the use of a most-similar-systems design, outlines the key concepts of adult relationship, relationships policy, and institution, and outlines my methods for gathering and analysing data.

My third chapter deals with the social and institutional context of each country. I show that trends of relationship formation and termination are broadly similar across the three countries (although there are differences in how the three countries gather data that hinder direct comparison), and explain key differences in legislative structures, electoral systems, participatory practices and the role of judicial review. The next three chapters outline the development of relationships policies in each country, observing and interpreting 
both consistent policies and policy changes that relate to relationship entrance and definition, relationship exit, and (for Australia and America), other policies that do not easily fall into these categories.

My seventh chapter adapts Gauthier's typology of family policy ideal-types for the purposes of characterising relationships policies to demonstrate how relationships policies in the three countries have shifted in relation to ideological positions on the state's role in adult relationships. My eighth chapter explores the role that early policy decisions have played in subsequent policy decisions in certain areas, and how political institutions have shaped relationships policy decisions by creating or denying opportunities for religious conservatives, women (especially feminists), LGBT activists, and legal interests. 


\section{CHAPTER 1: LITERATURE REVIEW}

\section{INSTITUTIONALISM AND POLICY}

The study of institutions has a long history in comparative political science and policy. Peters (1999, pp. 3-11) suggests that institutionalist thought was an important element of political philosophy from the time of Aristotle until the mid-twentieth century. This "old institutionalism" suggested that understanding how political systems were structured would allow analysts to predict their outcomes, regardless of the actors within the system. More recent "new institutionalist" scholarship provides a space for the integration of behaviouralist or rationalist approaches (Peters, 1999, pp. 15-17). Ultimately, however, all institutionalist approaches to comparative policy studies operate from the basis that political institutions govern the rules of policy development. Moser $(1999$, p. 2$)$ points out that, in a system where policies were automatically determined by the will of an ever-changing majority of voters, policies and markets would be highly unstable. Political institutions provide the necessary stability by shaping the incentives influencing actors, providing certain actors or interests with "agenda setting rights", creating veto points of varying strengths, and controlling the flow of information.

A number of scholars have attempted to ascertain the effect of a small set of institutional variables on government spending. Bradbury \& Crain (2001) find an association between higher levels of government spending and larger legislatures, and that bicameralism reduces this effect. Milesi-Ferretti et al. (2002, pp. 647-648) find that electoral system type is also important, as majoritarian systems tend to focus their spending on geographicallytargetable public goods, whilst proportional systems focus on universal transfers. These findings, though not directly related to relationships policy, do indicate that different electoral systems cause politicians to address different constituencies, so they may affect whose desires are privileged in relationships policy-making.

Orellana (2010, p. 622) finds that electoral systems affect how quickly countries respond meaningfully to controversial issues (same-sex relationships and climate change). Orellana suggests that countries with proportional electoral systems address these issues rapidly because their systems allow fringe parties to enter the political system and push for action. Ezrow (2011, pp. 316-317) finds that political parties in proportional systems adjust their policies to court the median voter, while parties in non-proportional systems do not. 
Ezrow and Orellana's findings seem somewhat contradictory, but it is possible that fringe parties simply allow new issues to become part of the mainstream political debate. Picot (2014, p. 141) further complicates these findings by suggesting that systems with large numbers of parties, including strong "anti-system" parties, only produce incremental reforms, and focus on specific groups of voters, while less polarised party systems will focus on policies that affect large numbers of voters.

Heidenheimer (1973) mixes cultural and institutional explanations of policy change in his comparison of the development of welfare and education services in Europe and the United States. Heidenheimer suggests that policy development is related to popular and professional faith in particular institutions, and beliefs about which level of governance (local, state, or federal) is appropriate for a particular policy. Moreover, the mass movement party form present in Europe could more readily present policies targeting "broad social goals" (rather than local interests) than the looser American parties (Heidenheimer, 1973, p. 335). Pedersen (2012, p. 299) finds that party organisations also affect the behaviour of representatives within multiparty systems. Where party organisations have more control over their representatives, these representatives will tend to pursue "policy purity" rather than "policy influence".

\section{COMPARATIVE POLICY STUDIES}

Comparative social policy, which originated in the 1970s with the work of scholars such as Wilensky, Heclo, and Titmuss, initially focused primarily on comparing levels of state expenditure, rather than analysing where this money was spent, or the effects of social policies on families. Wilensky (1975) used regression analysis to explain the growth of the "welfare state" (as expressed by growth in state welfare expenditure) as the outcome of structural and demographic changes. Heclo (1974, p. 317), produced a more complex picture of welfare development through a case study based approach. This allowed him to identify that important social policy changes in Britain and Sweden were not merely reactions to structural forces, but also reactions against the values embedded in past policies. Both Heclo (1974) and Titmuss (1974) pay attention to the character of welfare policies, rather than focusing exclusively on the amount of welfare provided by a state. Titmuss (1974, pp. 31-32) identifies "residual", "industrial achievement-performance" and "institutional redistributive" models to describe different bases of entitlement to welfare. 
Gøsta Esping-Andersen's theory of “welfare regimes” reinvigorated comparative social policy debates in the 1990s. Esping-Andersen studied the development of eighteen welfare states, identifying ideal-typical "socialist, conservative, and liberal regime-type[s]", based on the variables of "decommodification" and "stratification", around which these states clustered (Esping-Andersen, 1990, p. 222). These ideal-types are analogous to Titmuss' earlier models of welfare entitlement. Liberal welfare regimes are weakly decommodifying, as they use a residual basis for entitlement, in which the state limits its interventions to the neediest groups. Conservative regimes use social insurance mechanisms that compensate the unemployed based on their historic contributions; while these systems may be more decommodifying than residual models, they also reinforce income stratification, because higher earners normally receive greater compensation. Socialist (social democratic) regimes provide generous, often universal benefits, a more decommodifying and destratifying approach.

Esping-Andersen's theory has proved a fruitful source of debate, as a number of scholars have suggested adjusted ideal-types or additional ideal-types, whether to better reflect the diversity they see in the Western world (Arts \& Gelissen, 2002), or to offer a basis for classifying Majority World welfare states (Gough, 2004; Wood, 2004). Both EspingAndersen and his successors acknowledge the importance of the relationship between individual, family and state to particular welfare regimes, but the chief focus of their work has been on income protection, rather than family policy. Consequently, Esping-Andersen's classifications cannot adequately explain the development of family policy. Hantrais (1994) found that two supposedly archetypal conservative welfare regimes (France and Germany) deploy strongly differentiated family policies.

During the 1990s, however, a series of feminist scholars criticised conventional welfare regimes theory for its lack of attention to the effects of the welfare state on women. Lewis (1992, p. 161) points out that men typically receive benefits as workers, and women as carers, so that the welfare state reproduces a gendered division of labour. Orloff (1996, p. 53) sees the development of welfare states as "a transition from 'private' to 'public' patriarchy". She suggests that the post-war "family wage" contributed to women's dependency and that "traditional marriage" serves to maintain male dominance. Whereas Esping-Andersen's elucidations of his ideal-types paid particular attention to "traditional" families as an important part of the conservative regime in particular, his feminist critics suggest that women are used, in different ways, by all regime types (Lewis, 1992). O’Connor et al. (1999) 
point to a series of ideas carried from classical to "New" or "Social" liberalism to explain the patriarchal tendencies of liberal welfare regimes. In particular, the concept of the male breadwinner family was sustained under New Liberalism, partly as a result of the efforts of maternalist movements that celebrated domesticity (O’Connor et al., 1999, p. 51).

Orloff (2009, p. 320) suggests that an exclusive focus on social insurance and similar policies in comparative social policy betrays a "masculinist" worldview, necessitating a counterbalancing focus on the "social policy institutions" that shape women's welfare. Although Walby (2009) points out that most government institutions and policies are gendered, including monetary policy and the tax system, this refocusing has largely concentrated on family policy. A number of authors, including Jane Lewis (1992) and Gauthier (1996), offer their own interpretations of how different welfare regimes affect gender relations. Lewis examines how policy affects women's roles in the labour and care markets, with emphases on labour and income support policies, and the state's involvement in childcare provision. Gauthier concentrates more heavily on family policy, examining the development of child payments and maternity leave, but also examining regulations on contraception and abortion.

Lewis and Gauthier reference the male-breadwinner family in their alternatives to Esping-Andersen's system. Lewis (1992) suggests that there are "strong", "modified", and "weak" male breadwinner regimes, typified by Britain, France, and Sweden respectively. Gauthier (1996) identifies "pro-traditionalist" and "pro-egalitarian" regimes that aim to respectively reinforce and undermine the male breadwinner model. Alongside these, however, Gauthier identifies "pro-family but non-interventionist" regimes that are ambivalent toward the institution of the traditional family, intervening only to prevent extreme hardship, and "pro-natalist" regimes that intervene in the family for the purpose of raising national fertility levels. Castles (1996) identifies a "male-breadwinner" regime as a supplement (rather than alternative) to Esping-Andersen's classifications, describing the pre-1980s Antipodean welfare systems that used family wages to ensure that men could support their families (while providing lower wages to workers in female-dominated occupations).

While welfare states theorists' discussion of "male breadwinners" and "nuclear families" reflects the view of Halford \& van Acker (2012, p. 454) that social policy in the Western world focuses on marriage, discussion of policies around care provision and workforce integration dwarfs direct discussion of policies about adult relationships in comparative family policy. Focused, cross-national comparisons of adult relationships 
policies are rare. Van Acker (2008) provides an account of the development of marriage education policies in the United States, United Kingdom and Australia, through which governments may attempt to shape both the form and functioning of families (Halford \& van Acker, 2012). Freeman \& Lyon (1983), taking a highly critical view of marriage, suggest that legal treatment of cohabitation is drifting closer to that of marriage across a wide range of countries. Other authors adopt classificatory approaches to study cohabitation policies, both within the United States (Bowman, 2004) and cross-nationally (Garrison \& Scott, 2012).

Weston et al. (2012, p. 12) argue that policy-makers are interested primarily in assessing or addressing the effects of changing patterns of family formation at the expense of supporting them in their functioning. However, the New Zealand Families Commission's incoming briefing (Ministry of Social Development, 2004) focused on family function, pointing to a need to support a wide variety of family forms to fulfil their functions. Glennon (2008, p. 25) suggests that the importance of form in British family policy eroded towards the end of the twentieth century with a shift towards the "contractualization of adult relationships". Policies that target family form may be seen as unjust interventions into the private lives of consenting adults. Theoretically, this should be salient throughout the "liberal" world, given the liberal conception of family and state as separate spheres (O’Connor et al., 1999).

\section{FAMILY LAW}

The development of some areas of relationships policy is addressed in family law literature. Harrison (2002) and Atkin et al. (2013) describe major changes in family law in Australia and New Zealand respectively, both in technical terms and, to an extent, ideological terms, and discuss some of the social conditions surrounding these changes. Atkin et al. (2013, pp. 648, 655) suggest that a shift in the basis of concepts of family from status to function and a recognition of the "paramountcy" of protecting children's interests are central to changes in family law in New Zealand. Harrison (2002, pp. 9-10) identifies the increased use of dispute resolution as a key development in Australia. Graycar (2012, p. 243) suggests that the care of children has become the most contested area of family law in Australia, rather than matters directly connected with relationships.

Concerning the United States, Garrison (2008), like Bauman (2004), points out that, while the prevalence of bars on court protection of cohabitants has diminished, they have largely been replaced by contracting, or in some cases registration, rather than "prescriptive" 
measures. Ver Steegh (2008) suggests that alternative dispute resolution is also an increasingly important part of American family law, although court funding constraints may threaten some services. In addition, according to Oldham (2008), property division regulations at divorce are becoming increasingly similar, as common-law states have adopted community property at separation, but there remains a great variety in what is considered property.

While this work is valuable for describing the trajectories that various elements of relationships policy have taken, it is not necessarily as useful for explaining why particular changes have or have not taken place. While Garrison (2008) and Ver Steegh (2008) compare American policies to those of similar countries (including, in the case of Garrison, New Zealand and Australia), they do not attempt to explain the differences. Moreover, while these authors relate changes in family law to changes in society (Atkin et al., 2013, pp. 665-666), they do not provide a clear picture of how these social changes occur. This is problematic because, while policies have certainly changed in each country, and it is reasonable to suggest that social changes are an important causal factor, these changes have not been uniform. Analysing the development of relationships policies from an institutionalist perspective provides an opportunity to explain how similar social trends might produce different policy outcomes in different countries. 


\section{CHAPTER 2: METHODOLOGY}

This research takes a theory-building approach to comparative social policy, attempting to explain variation in relationships policies within similar welfare regimes by exploring the institutional contexts in which policy actors attempt to translate social changes and ideas about marriage and family into policy. Without using a comparative approach it is impossible to determine which aspects of the complex system that is a country are genuinely significant. While making absolute generalisations about policy development remains problematic because of the sheer variety that exists within and between countries, comparative research nonetheless allows us to focus on the most significant factors. I use a "societal" style of analysis that recognises policy development as the outcome of the interaction of a variety of factors on multiple levels (Hantrais, 2004). In order to understand how these interactions occur within particular settings, I use a case study-based qualitative approach.

\section{CASE SELECTION}

Case study approaches to comparative research require careful case selection. Landman (2008, p. 70) suggests that either a Most Similar Systems or Most Different Systems design is preferable. Most Similar Systems is most appropriate when attempting to isolate the variables that cause similar cases to produce different outcomes, while Most Different Systems is useful for determining the variables that cause different cases to produce similar outcomes (Gerring, 2008, pp. 668-673). I use a Most Similar Systems design because my central research interest is determining why variations in relationships policies exist in spite of similar social trends

The complexity of countries as "systems" means that it is impossible to control for every possible relevant factor. In selecting my cases, I used welfare regime and family policy regime types, and patterns of relationship choice as the bases for similarity. According to these criteria, New Zealand, Australia, and the United States are similar systems because their welfare regimes are similarly classified in the literature as "liberal" or "residual" (EspingAndersen, 1999, pp. 77, 85), and their family policy regimes are similarly classified as "nonfamilialist" (Esping-Andersen, 1999, p. 86), or as "low support" (Gauthier, 1996, p. 189). While there are some differences in relationship formation patterns between the three 
countries, and some statistics are difficult to compare directly (as discussed later), similar trends are nevertheless apparent in each country.

\section{CONCEPTS}

Jones (1985) and Kennett (2004) suggest that articulating transferrable concepts is a key problem for comparative research. While studying equivalent phenomena in each case is usually most troublesome when language differences are involved, actors and institutions may differ in their understandings of key concepts such as family both inter- and intranationally. In this case, however, many such concepts are objects of study; how a state defines family in its policies may be significant for identifying the model of relationships policy at hand. Defining family through reference to marriage, for example, may be a marker of a pro-traditionalist outlook.

\section{Adult relationship}

The key concepts in this research are adult relationship and relationships policy. Adult relationship describes a personal relationship between two (or, in theory, more) adults that involves a significant level of interdependency. An adult relationship becomes significant for this research when a state elects to make a policy (relationships policy) - that regulates its formation, character or conclusion, or that employs the relationship or a function associated with such a relationship, as the basis for rights, responsibilities and entitlements.

While such open-ended definitions of adult relationship and relationships policy are somewhat awkward, they are necessary to reflect the diversity of relationships which states may now potentially recognise. In my previous work comparing the development of similar policies in Malaysia and Singapore, the term marriage policy covered the relationship interventions at hand. Within liberal democracies, however, marriage describes only one set of recognised adult relationships. Cohabitation, while potentially incorporating a greater variety of relationships, is also unsatisfactory because, while some government policies may target cohabitants rather than a particular relationship status, people do not necessarily have to live together to be partners in a significant relationship.

\section{Institutions}

Hodgson (2006, p. 2) suggests that, while the meaning of institutions is highly contested within the social sciences, the term essentially describes "systems of established and prevalent social rules that structure social interactions". This includes both "formal" and 
"informal" institutions - although most institutions will consist of a mixture of social conventions and formal rules. Most of the institutions examined in this research are primarily formally-constituted, but it is be important to consider how informal conventions interact with formal rules within some of these.

\section{DATA COLLECTION}

The initial stage of data collection involved reading literature on the development of family policy and family law in each country to identify relevant legislation, court judgments and other policy documents. While the main time scope for data collection covered policies from 1990 to July 2014, I collected some data on significant policy changes outside this time frame in order to tell the complete policy "story" for each country. To ensure that I would identify recent developments, I searched government, news, and political party websites for adult relationship-related terms. In the case of the United States, where many relationships policies are developed at the state-level, I selected five states (California, Hawai' $i$, Louisiana, Oklahoma, and Vermont) to investigate deeply based on their purported significance in the literature as leaders of significant changes in relationships policy, collecting the entirety of their family or "domestic relations" legislation. To supplement this, I used the most recent edition of the National handbook of state laws (Leiter, 2008) and collected narrower samples of policies from a wider range of states on particular issues (Arizona, Arkansas, Georgia, Kansas, New Jersey, New York, Texas and Wisconsin).

In order to contextualise these policies, I gathered both primary and secondary data on policy debates, social changes, interest group activities, and political institutions and rules. The primary sources included manifestos, constitutions and websites (where available) for major political parties or presidential candidates; legislative debates; legislative committee reports and interest group submissions; law commission reports; and interest group websites. In order to access historical websites, I used the internet archives of archive.org, the National Library of New Zealand, and the Library of Congress. My secondary sources included social and political histories, literature on policy-making and historical news sources.

\section{ANALYSIS}

\section{Characterising policies}

The first step in my analysis involved a broad classification of policies as a) policies concerning relationship formation and definition, b) policies concerning relationship 
termination, or c) policies involving incentive systems. These categories are not mutually exclusive, particularly in the case of property division laws for de facto relationships, which may establish the formation of a relationship only in retrospect, but they served as a useful entry point to the data. After completing an overview of the relationships policies in each area for each country, I used the ideological positions underpinning Gauthier's ideal-types to interrogate these policies. This involved asking:

- What is the purpose of state intervention?

- How does a policy reinforce or undermine the institution of the traditional family?

- What level of family function does a policy seek to achieve?

From this work, I devised a set of policy positions that correspond to each ideal-type, and used these to identify the character of policies and policy changes, and to tentatively apply this to the relationships policies of each country as a whole.

\section{Institutional influences}

In developing an explanation for differences in how the character of relationships policy in each country has changed over time, I adopted a mixed institutionalist approach. Firstly, I drew from historical institutionalist concerns about the importance of "policy legacies" in controlling the policy process through "path dependency" and - in consequence - what policies emerge (Schmidt, 2009, p. 128). This involved isolating policy areas to determine whether they meet three criteria for path dependence: contingency, early sensitivity, and inertia (Mahoney, 2000, p. 511). I then explored the question of why path dependence would occur in particular relationships policy areas and the effects of policy stability in one area on other areas.

Path dependence is an incomplete explanation for uneven policy development because it does not adequately explain the forces that cause policy changes. While Strach's (2007, pp. 12-13) focus on "policy gaps" is useful for showing how early policy decisions react with changing social norms, Strach does not fully explore the influence of policy-makers in choosing how to address these gaps. Peters (1999, pp. 116-117) suggests that how institutions shape the interaction of political interests is significant for determining policy outcomes. My previous research into Malaysia and Singapore, which found that how electoral and party systems shaped the interaction of different ethnic, religious, and gender interests affected the development of marriage policies, supports this theory. I take a holistic approach, examining how different levels of the policy-making system interact to give veto 
and agenda-setting powers to particular interest groups and alliances of interest groups. While this cannot fully explain policy decisions, as policy-makers are, ultimately, people, with their own beliefs, priorities, strengths and weaknesses, who will not always respond 'rationally' to the situations that confront them, and strong leaders may certainly have outsize effects, political and policy institutions will nevertheless affect what kinds of people enter influential positions, and what those positions allow them to do. 


\section{CHAPTER 3: SOCIO-POLITICAL CONTEXTS}

\section{RELATIONSHIP CHOICE TRENDS}

Changing patterns of relationship formation provide one explanation for changing relationships policies. However, a singular focus on demographic change cannot sufficiently explain the variation that exists in how policies have changed (discussed in chapters 4-7) because, although marriage remains most popular in the United States, each country has experienced similar, dramatic changes in relationship formation and exit over recent decades. During World War II and its immediate aftermath, marriage rates rose dramatically (Department of Statistics, 1988, p. 136; Espenshade, 2005, p. 205; Krupinski, 1974, pp. 6-9), and while marriage rates fell somewhat after the post-war boom, they rose thereafter to new peaks. Australia reached a crude marriage rate (CMR, marriages per 1,000 population) of 9.3 in 1970 (ABS, 1974, p. 172), while New Zealand peaked at 9.5 in 1971 (Statistics NZ, 2014b), and the United States reached 10.9 in 1972 (NCHS, 1983b, p. 4). Since this point, the marriage rates in each country have dropped dramatically, although this has been most pronounced in New Zealand, where the CMR hit a low of 4.3 in 2013 (Statistics NZ, 2014b), while the United States reached 6.8 in 2011 (CDC, 2013c). Australia shows a slightly different trend, as its CMR hit 5.3 in 2001, and has since remained stable (R. E. Weston, Qu, \& AIFS, 2013, p. 3).

These changes have been accompanied by corresponding changes in the age of first marriage. High marriage rates were driven by large numbers of early marriages; in the postwar period median ages at first marriage in each country dropped to 20-21 for women (Krupinski, 1974, p. 9; NCHS, 1974; Statistics NZ, 2001, p. 7). Krupinski suggests that the rise of early marriages had a flow-on effect in the character of marriage, because young couples without the resources necessary to establish a joint household needed two incomes to develop their asset base. From around 1975, however, the median age at first marriage began to rise; the median age at first marriage for women has risen to 28.6 in New Zealand, 28.1 in Australia, and 27.4 in the United States (AIFS, 2014; Statistics NZ, 2014d; US Census Bureau, 2013) ${ }^{1}$.

A rise in cohabitation as a prelude or alternative to marriage has contributed to these falling marriage rates and increasing ages of marriage. Comparing cohabitation statistics is

\footnotetext{
${ }^{1} 2013$ estimates for New Zealand and the US, 2012 estimate for Australia.
} 
somewhat problematic, particularly between countries, as definitions of cohabitation vary substantially. Nevertheless, it is clear that rates of cohabitation have risen considerably. In New Zealand, 409,000 people identified as de facto partners in 2013, 22.3\% of partnered respondents, close to 300,000 more than in 1988 (Department of Statistics, 1988, p. 141; Statistics NZ, 2013).

Fewer than $6 \%$ of partnered Australians identified themselves as being in a de facto relationship in 1986, but the 2011 census found that $16.2 \%$ of the "socially married" were in "de facto marriages" (ABS, 1997, p. 24, 2011). These references may not necessarily capture all cohabitants, however, as many may not consider themselves married, or may even be cohabiting, rather than legally married, to avoid the concept. The ABS has also identified a considerable increase in the rate of premarital cohabitation. Only 3\% of couples who married in the 1960s and were still married in 2006-7 cohabited before marriage, while more than half of couples did so in 1992, and the proportion is now close to $80 \%$ (ABS, 2009, p. 10, 2012, p. $13)$.

The US Census does not record cohabitants. However, Bumpass \& Sweet (1989, p. 617) estimated that, in 1987-1988, around 4\% of Americans older than 19 were cohabiting, including a sixth of never-married 25-34 year olds. The Centers for Disease Control (CDC, 2010, pp. 17-18) does not provide a figure for the whole population, but estimated that around 9\% of Americans cohabited in 2002, including about a third of never-married 25-34 year olds. Copen et al. (2013, p. 9) found that cohabitation was the first union for somewhat fewer than half of American women who had lived in a coresidential union in 1995, but by 2006-2010 marriage was the first union for only a third of this group of women.

Divorce is commonplace in contemporary society, although it is not increasing in prevalence as many Americans apparently believe (Pew Research Center, 2010, p. 19). The rate of divorce in each country rose steadily from the early-1960s to early 1980s. Between 1961 and 1982, the Australian crude divorce rate (CDR, divorces per 1,000 population) grew from 0.7 to 2.9 (ABS, 2008), while the American CDR grew from 2.2 in 1961 to 5.2 in 1980 (NCHS, 1983a, p. 4). Statistics New Zealand (2014c) reports the divorce rate per 1,000 marriages rather than a CDR; this climbed from 3.2 in 1961 to 11.9 in 1981.

Wolfinger (2005, p. 410) suggests that conservative claims that no-fault divorce is responsible for these increases lack a sound basis. It is clear from the Australian and New Zealand rates that no-fault divorce causes spikes in divorce rates in the near-term; the New 
Zealand divorce rate spiked to 17.9 in 1982 (Statistics NZ, 2014c), when couples previously blocked from divorcing could fulfil the two-year separation requirements of the Family Proceedings Act 1980, while the Australian CDR spiked to 4.5 in 1976 in the wake of the Family Law Act 1975 (with a one-year separation requirement). These spikes were not permanent, however, and divorce rates have declined slowly since the 1980s; the Australian CDR fell to 2.2 in 2012 (ABS, 2013), the American CDR fell to 3.6 in 2011 (CDC, 2013c), and the New Zealand rate of divorce per 1,000 marriages fell to 9.4 in 2013 (Statistics NZ, 2014c).

\section{Cleavages}

National-level patterns in relation formation and exit do not reflect the deep diversity present within each country. Not only do different age groups display different relationship patterns, but these patterns also differ across ethnicity, socioeconomic status, and geography. In Australia, for example, the Northern Territory CMR has stood well below that of the rest of Australia since 1962, while its residents have been much more likely to form de facto relationships; in 1991, when the Territory passed its De Facto Relationships Act, $18.5 \%$ of couples were de facto relationships, more than twice the figure for the country as a whole (ABS, 1997, p. 25).

America displays an immense variety not only of CMRs and CDRs, but of CMR and CDR trends. West Virginia marriage and divorce rates have remained static between 1990 and 2011, while the South Carolina CMR dropped by 55\% over the same period, and the Arizona CDR dropped 43\%. While the Arkansas CMR has dropped 32\%, it remains at 10.4 (the highest outside the destination wedding states of Hawai'i and Nevada (CDC, 2013a, 2013b).

There are striking differences between the relationship formation patterns of indigenous and non-indigenous New Zealanders and Australians. Māori and Aboriginal Australians are both less likely to be partnered and more likely, if they are partnered, to be in a de facto relationship (ABS, 2011; Statistics NZ, 2013). This may be partially explained by the different age profiles of indigenous and non-indigenous groups, but Māori are also more likely than Pākehā to form de facto relationships across every age bracket from age 20. In part these differences may be cultural; Heard (2011, p. 134) suggests that the role of “community-sanctioned consensual unions" explains the differences, and Ruru (2005, p. 330) points out that the formalities surrounding pre-European Māori "marriages" could vary 
considerably, and did not have the same implications for property rights as European marriage.

There is a similar ethnic divide in the United States. Elliott et al. (2012) show that, while black Americans were more likely to be married than white Americans prior to the post-war marriage boom, this has now reversed, and black women in particular are much less likely to marry than white women. Like Heard, Elliott et al. suggest that there are cultural explanations for this, such as the greater importance of extended families in black society, greater acceptance of non-marital parenting, and low levels of trust in low-income communities that discourage marriage. They also identify the substantially higher imprisonment rate for black men as a factor.

Differences in relationship formation across ethnic divides may also relate to differences along socioeconomic divides, as marriage is becoming increasingly associated with economic security. Heard (2011, p. 125) points out that increasing cohabitation rates are not primarily the result of educated women shunning marriage. Sassler \& Miller (2011, p. 163) found that, in America, the proportion of high-school-educated women who had cohabited at some point grew at over twice the rate of university-educated women between 1987 and 2002.

Heard (2011) found a similar effect in Australia and, to a lesser extent, New Zealand. While educated Australian women have held liberal attitudes toward marriage for some time (English \& King, 1983, p. 36), these attitudes appear to have resulted in deferring, rather than rejecting marriage, while the least educated women are now unlikely to marry. This trend makes sense within the newly neoliberalised economies of Australia and New Zealand where, without the guarantees of full employment or the family wage, unskilled men make poor prospective partners for low-income women, for whom they may become a burden rather than a source of stability. At the same time, the growing influence of egalitarian views of marriage mean that highly qualified women can expect their partners to view them as equals within marriage.

\section{KEY INSTITUTIONS}

Because there are significant differences in how relationships policies have changed despite similar demographic changes, it is important to examine the differences in the decision-making processes through which these demographic changes are interpreted. 


\section{Electoral systems}

Electoral systems are a core source of variations in opportunities for interests. The different electoral systems in each country, in combination with party structures, shape the makeup of legislatures and the balance of power between individual legislators and political parties. Both the United States and Australia operate federal systems with bicameral legislatures (with a few exceptions at state and territory level), but the electoral systems in each country function very differently. While New Zealand has a unitary government, and unicameral legislature, its electoral system and party structures share similarities to those of Australia.

While the United States uses a single-member, first-past-the-post (FPP) system, Australia uses a combination of single-member and multi-member preferential systems for its lower and upper houses respectively. While single-member systems tend to disadvantage third parties, because they reward local, rather than broad-based support, the existence of a preference system does at least allow voters to identify their "true" preference without fear of vote wastage. The multi-member electorates for upper houses in Australia provide more substantial opportunities for minor parties, which regularly hold the balance of power, forcing major parties to build policy coalitions with minor parties to pass legislation. New Zealand moved from FPP to a mixed-member proportional (MMP) system following a referendum in 1993. MMP in New Zealand entitles parties to representation in proportion to their nationwide "party vote", provided that they win at least $5 \%$ of the party vote or one of a number of local electorates (determined by FPP). This system gives minor parties access to Parliament, and forces major parties to negotiate with them to form a government or pass legislation, but the entrance thresholds may block potential entrants and dissuade voters from selecting a party that may not achieve the threshold.

The United States uses a primary system for candidate selection, which produces very different results to the internal party mechanisms employed in Australia and New Zealand. The primary system is a "democratised" form of candidate selection that allows the voters of an electoral district to select their preferred candidate rather than allowing a local or national party organisation to make this decision. Mayer (2001, p. 12014) points out that this weakens these party organisations and enables "outsider" candidates to win elections. Moreover, the local focus of selection provides an incentive for representatives to play to the preferences of their electorates, rather than to those of the wider party, so it may be difficult for the leaders 
of a governing party to enact controversial aspects of their agenda, even if they theoretically control both chambers of a state or federal legislature and its executive.

By contrast, the major parties of Australia and New Zealand use internal selection processes that rely, depending on the party and type of election at hand, on some combination of fee-paying party members and party officials (Crook, 2009a, 2009b; NZLP, 2014, sec. 301-366; NZNP, 2013, sec. 86-134). This means that political parties in Australia and New Zealand exercise a great deal of influence over their representatives. Farrell \& McAllister (2006, pp. 132-133), commenting on Australian senate selection procedures, point out that candidates who are suspected of being less than completely loyal to their party - or even to a powerful faction within their party - may move down their party's list or lose their place altogether. Internal selection allows egalitarian parties to enforce affirmative action policies, although how effectively these policies work may depend on how the specific rules at hand interact with the electoral system; the New Zealand Labour Party (NZLP) has not been able to achieve its gender equality targets because of poor party vote results (Strongman, 2014). Labo(u)r parties also require their candidates to sign a pledge to act collectively (Brett, 2003, p. 41; NZLP, 2014, sec. 300), giving the party organisation further control over its members' actions within Parliament.

\section{Citizen \& stakeholder participation}

There are a number of formal and informal mechanisms for interested parties to participate in policy-making processes outside elections. In all three countries legislative committee hearings provide an opportunity for citizens and organisations to testify about policy. Citizens may also participate in, and in some circumstances instigate referenda. There are, however, strong differences between the countries in the effectiveness and openness of these forms of participation.

\section{Referenda}

Referenda in New Zealand and Australia may be either binding or non-binding, depending on their circumstances. In New Zealand, Parliament may initiate a binding referendum, usually on a constitutionally significant issue such as the electoral system, but this occurs very rarely (Morris, 2004, p. 117; Preston, 1997). Otherwise, a large number of citizens may sign a petition to call for a non-binding referendum; the Citizens Initiated Referenda Act 1993 requires petitioners to collect signatures from 10\% of the electoral roll (300,400 signatures at 20 July 2014) (Morris, 2004, p. 122; NZEC, 2014). This necessitates 
significant organisational efforts to bring issues to a vote, and nothing requires the government to take the public's decision into account. Calls for binding citizen-initiated referenda have been led largely by conservative and populist parties (Conservative Party, 2014; Kiwi Party, 2008; New Zealand First, 2008), indicating that these parties believe that their agendas are compromised by Parliamentary supremacy. New Zealand relationships policies have not been directly affected by referenda, although New Zealand First called for binding referenda on civil unions and same-sex marriage (D. Jones, 2004a; W. Peters, 2013).

Australia uses binding referenda principally in deciding constitutional issues; the powers of the federal government are dictated by the federal constitution, which may only be changed by referendum (Kildea \& Williams, 2010, p. 22). While state referenda have reasonable success rates, federal referenda usually fail, and none has passed since 1977, which has forced the federal government to turn to agreements from state parliaments to expand its powers (Williams \& Hume, 2010, pp. 101-102). While there is no guarantee that the federal government would have acted more quickly on de facto relationships policy without this requirement, the absence of authority to act in this area created a space for state governments to act.

Referenda play an even greater role in the United States, where they are usually required to approve state constitutional amendments. Although the precise requirements involved in proposing an amendment vary between states, many states rely on citizens' petitions, allowing well-organised interest groups a mechanism for shaping the behaviour of state legislatures and courts. Dinan (2011, p. 1014) points out that state amendments are important to actors concerned about preserving a policy from future legislators; this makes the process particularly useful for conservative actors, including same-sex marriage opponents. This is confirmed by Haider-Markel (2003, p. 443), although changing attitudes toward same-sex marriage may mean that direct democracy is no longer such a serious threat to LGBT rights.

\section{Committees and inquiries}

Formal committee hearings also play a role in the political systems of each country, giving stakeholders an opportunity to deliver their opinions to politicians, particularly on bills before the legislature. However, opportunities to participate are not necessarily distributed evenly amongst stakeholders. While select committees in New Zealand and Australia receive written and oral submissions from the general public (Department of the Senate, 2014; New 
Zealand Parliament, 2012), federal legislative committees in the United States are more selective in calling witnesses (Catholic Health Association, n.d.), generally relying on lobbyists and "experts" (Schultz \& Vile, 2005). The logistical requirements of attending a congressional hearing may exclude vulnerable potential witnesses. Ultimately, however, there is no requirement for a committee in any country to genuinely engage with citizen and stakeholder testimony.

Some areas of family law are dealt with by extra-parliamentary bodies such as law commissions. These institutions, which exist in New Zealand (NZLC, 2014), Australia (ALRC, 2014) and its states (NSWLRC, 2013), and a number of American states (including California and Connecticut (CALRC, 2014; CTLRC, 2014a)), are bodies of legal experts that investigate possibilities for legal modernisation in areas appointed by governments or legislatures. While law commissions attempt to engage in public consultation, they focus particularly on the legal community (ALRC, 1987, pp. 6-7; NZLC, 1997, pp. 3-5, 171-172). American commissions are both less prevalent and less independent than those in Australia and New Zealand. While commissions in Australia and New Zealand generally consist of leading law practitioners and academics, American commissions include elected legislators and political appointees (the Michigan commission, for example, includes two senators, two representatives, and four members appointed by a joint committee (Michigan Legislative Council, 2014).

\section{Judicial review}

Judicial review of legislative and administrative decisions is considerably more prevalent in the United States than either New Zealand (where it is almost impossible) or Australia. Because New Zealand lacks a clearly-defined and entrenched constitution, its courts lack the power to rule legislation incompatible with the rights and freedoms accorded to individuals and governments. The Australian constitution lacks a bill of rights, so petitions by individuals against legislation that disregards their perceived rights and freedoms have little basis. The constitution does, however, identify the powers of the federal government, so federal legislation that goes beyond these powers or state legislation that trespasses upon the powers of the federal government may be subject to judicial review.

United States courts participate in policy processes on a significant scale, potentially determining both the legitimacy of policies, and their implementation (Kagan, 2004). Both federal and state constitutions in the United States contain bills of rights, so it is possible for 


\section{5}

people to petition either federal or state courts on the basis of these rights being violated, or on the basis of a government exceeding its authority. Consequently, actors may engage in judicial level-switching, changing their focus from state courts to federal courts and vice versa to exploit differences between federal and state constitutions and the attitudes of the judicial systems (Hodder-Williams, 2003, p. 152). The availability of judicial review works against legal discrimination, and is difficult for pro-traditionalists to exploit if they are seeking to constrict rights, but it cannot serve a thorough pro-egalitarian agenda as on its own it is incapable of disestablishing institutions or creating new ones to compete with 'traditional' marriage . 


\title{
CHAPTER 4: NEW ZEALAND
}

\section{RELATIONSHIP ENTRANCE AND DEFINITION}

\begin{abstract}
Marriage
New Zealand's Marriage Act 1955 governs the process of marrying. The Act identifies who may legally marry and establishes license issuance and solemnisation processes. The Act did not originally specify the sex of those marrying, relying on the unstated assumption that marriage was a heterosexual relationship. The Christian Coalition's 1996 manifesto (contemporary with America's Defence of Marriage Act) proposed defining marriage as "the legal contract of two people of the opposite sex committed to a life-long loving relationship" (Christian Coalition, 1996, p. 8), but their failure to reach the electoral threshold removed the potential for this to become part of a post-election agreement. Consequently, the first definition of marriage in the Act came from the Marriage (Definition of Marriage) Amendment Act 2013, which defined marriage as the "union of 2 people, regardless of their sex, sexual orientation, or gender identity".

The Marriage Act does not explicitly enforce monogamy, but the Crimes Act 1961 (s. 205-206) criminalises bigamy, with a potential sentence of up to seven years' imprisonment, covering marriages within New Zealand and, for citizens and usual residents, marriages overseas. However, polygamous marriages contracted legally elsewhere before migrating to New Zealand are fully recognised.

Marriages involving minors (16-17; 16-19 until 2005) require the consent of parents or guardians (Marriage Act, 1955, s. 17-20). Although the Status of Children Act 1969 eliminated the language of "legitimacy" from the Act, a young person's parents' marital status remains a factor in determining whose consent is valid and necessary for the marriage. In certain circumstances, the necessity of a father's consent depends on whether he had ever married the mother of the young person in question. This subtly acknowledges the "traditionalist" view that marriage carries the presumption of paternity (Baskerville, 2006, p. 61). However, if a minor's parents cohabit or they live with only one parent, relationship status is irrelevant in determining who must consent.
\end{abstract}

The Marriage Act also provides a framework for the ceremonial or sacramental aspects of marriage. While marriage is legally a contract between two people and the State, 
the involvement of representatives of community organisation and religious bodies in conducting marriages acknowledges the place of civil society and religion in marriage (Marriage Act 1955, s. 7-14A). The Act also acknowledges the religious practices of Quakers (and, following the Human Rights Amendment Act 2001, other groups with similar attitudes toward religious leadership), exempting them from the requirement for an approved celebrant or registrar (Marriage Act 1955, s. 14A, 32).

Celebrants became a subject of debate over the Marriage Amendment Act 2013, which presented the question of whether celebrants could refuse to conduct same-sex marriages if this would violate their personal beliefs. Celebrants discriminating against homosexual couples would potentially violate the Human Rights Act 1993, particularly given that they operate on the State's behalf. The legislation's sponsor argued that s. 29, which states that marriage licenses do not oblige celebrants to perform marriages, provided sufficient protection (Wall, 2013, p. 8524). The committee reviewing the Bill nevertheless adopted a specific exemption for celebrants representing organisations opposed to same-sex marriage.

\section{Civil unions}

The Civil Union Act 2004 (CUA), which created civil unions, mirrors the processes of the Marriage Act almost exactly. When introduced, the CUA offered formal recognition and protection for homosexual couples on an (approximately) equal basis to marriage, and an alternative status for heterosexual couples seeking state recognition without traditional connotations. The Marriage Act 2013 further reduced the legal distinctions between the relationships, although some minor differences highlight civil unions" "deinstitutionalised" character.

The first such difference is in the processes for allowing civil unions and marriages within the "prohibited degrees of affinity" (CUA, 2004, s. 10; Marriage Act 1955, s. 15). The Acts forbid people marrying or entering civil unions with close blood relations ${ }^{2}$ or (by default) the former spouse or civil union partner of an ancestor or descendant. The latter barrier may be waived more simply for a civil union. The Marriage Act allows the High Court to waive the barrier provided that the couple's conduct did not contribute to terminating either party's marriage. This deters infidelity and other potentially relationshipdestroying behaviour by withholding the sanction of marriage, although its limited

\footnotetext{
${ }^{2}$ Cousin-marriages are acceptable.
} 


\section{8}

application means that it principally defends parent-child relationships, rather than marriage itself. The CUA requires a Family Court application and offers no grounds for refusal. This marks marriage as a more exclusive institution with higher standard of commitment and fidelity, but also undercuts the Marriage Act's practical effect as couples may receive equal treatment by "only" contracting civil unions. In governing consent to the union of minors, the CUA (s. 19-20) also replaces the veiled legitimacy language of the Marriage Act with a functionalist focus on guardianship.

The solemnisation of civil unions highlights their deinstitutionalised character. Whereas marriage celebrants may operate due to their standing within an approved community organisation or religious body, civil union celebrants hold their status in their own right, although this may be related to the "interests of the public generally, or of a particular community" (CUA, 2004, s. 26). This reinforces the idea that civil unions are a private affair unconnected to the practices and beliefs of traditional institutions. This deinstitutionalised character has not proved attractive to New Zealanders; only nine couples have transitioned from marriage to civil union (61 heterosexual couples have done the opposite) (Statistics NZ, 2014a), indicating that their openness to heterosexual couples was not the result of a great groundswell of public desire to escape marriage.

\section{DE FACTO RELATIONSHIPS}

The beginning of a de facto relationship is less clearly defined than that of a marriage or civil union. The Property (Relationships) Act 1976 (PRA) ${ }^{3}$ (which is principally concerned with relationship exit) and Interpretation Act $1999^{4}$ determine the existence of de facto relationships for different purposes, using different sets of criteria.

While each Act attempts to provide a functional definition of de facto relationships, and leaves substantial room for courts' or administrators' interpretations, the PRA provides a more concrete mechanism for determining whether de facto relationships exist. Under the PRA, a relationship between any two people is a de facto relationship if it involves two adults who "live together as a couple... and who are not married to, or in a civil union with, one

\footnotetext{
${ }^{3}$ Following the Property (Relationships) Amendment Act 2001.

${ }^{4}$ Following the Relationships (Statutory References) Act 2005 and associated Acts.
} 
another" (PRA, 1976, s. 2D(1)). Section 2D(2) provides criteria that courts may use to determine whether people "live together as a couple" 5

In its initial stages, the Relationships (Statutory References) Bill (RSRB) utilised the definition and criteria of the PRA in its amendments to the Interpretation Act. However, the eventual collection of Acts derived from the RSRB replaced this definition by defining a de facto relationship as two people living together "as a couple in a relationship in the nature of marriage or civil union" (Interpretation Act 1999, s. 29A). It eliminated the specific functional criteria specified by the PRA, allowing interpreters to determine whether a relationship exists by considering "all the circumstances of the relationship" and the context and purpose of the law under which the determination is necessary. Consequently, while the Interpretation Act 1999 allows courts and administrators to treat relationships on a functional basis, it also points to a normative model of how a relationship should operate.

Proponents of the Property (Relationships) Amendment Act 2001 (PRAA) and RSRB primarily employed justice- and rights-based arguments, while opponents used liberal arguments based on freedom of choice and conservative arguments focused on protecting the “institution of marriage”. In introducing the RSRB, Labour's David Benson-Pope (2004, p. 13951) argued that the New Zealand Bill of Rights Act 1990 and Human Rights Act 1993 compelled the state to stop discriminating between relationships that shared the core characteristics of being "committed, exclusive, and stable", while Green MP Metiria Turei (2004, p. 13957) supported the RSRB because it would correct injustices experienced by sexual minorities.

Opponents suggested that these laws would decrease the likelihood of people entering traditional marriage by eliminating its legal advantages, and that the absence of a commitment to permanence meant that de facto relationships were not functionally equal in any case (N. Smith, 2004). Others suggested that the RSRB would eliminate couples' right to live without the rights and responsibilities of marriage (Franks, 2004, p. 13958; D. Jones, 2004b, p. 13956). Jenny Shipley (2000, p. 6706) used a similar argument about merging the matrimonial and de facto property regimes in the PRAA, suggesting that the government was “marrying 236,397 people" through the bill.

\footnotetext{
5 Including duration, cohabitation, sexual intimacy, financial dependence or interdependence, property "ownership, use, and acquisition", mutual commitment, children, household labour-sharing, and public recognition as a couple.
} 


\section{RELATIONSHIP EXIT}

The PRA and FPA govern the process of leaving a relationship in New Zealand, in order to minimise conflict and achieve just outcomes for partners post-separation.

\section{Property division}

When first enacted, the Matrimonial Property Act 1976 (later the PRA) dramatically advanced the role of gender equality as a principle in dividing relationship property. Judges formerly exercised discretion in recognising nonfinancial contributions to marriages when making property determinations, with uneven results (Atkin et al., 2013, p. 662). Consequently, women were often severely financially disadvantaged by divorces. The Matrimonial Property Act established a principle of equal division (not equal outcomes) through a "50-50 split on a clean break, no fault principle" (Tolley, 2001, p. 8629).

Besides protecting women from the consequences of divorce, the Act also served to promote marriage as the ideal family form. The Act covered only legally-contracted marriages, leaving de facto couples and Māori customary marriages unprotected. Henaghan \& Tapp (1992, pp. 23-24) attribute the exclusive focus on marriage to the change of government between the introduction and passage of the Matrimonial Property Bill. The Third Labour Government, which introduced the Bill in 1975, supported protection for de facto relationships but lost that year's election. National's Minister of Justice David Thomson favoured limiting protection to legal marriage to encourage people to demonstrate their responsibility to their partner by marrying (Henaghan \& Tapp, 1992, p. 24).

The PRAA changed the principle behind property division. While equality remains a core value of the PRA, the amendments changed the nature of this equality. The Act now focuses on equality of outcomes rather than equality of division. Its principles (PRA, 1976, s. $1 \mathrm{~N}$ ) begin from the idea that "men and women have equal status, and that equality should be maintained and enhanced". The Act acknowledges that the division of labour within a relationship affects partners' financial situations beyond the course of the relationship. A "just division of property" under the Act's principles compensates for the "economic advantages and disadvantages" that accrue through the relationship. This may include compensating partners for their career sacrifices or their role in promoting their partner's career. Consequently, the PRAA was a significant egalitarian step, attempting to deconstruct structural inequality. The amendments certainly exceeded those envisioned by National in its 
long-delayed response to a 1988 working group; National's proposed amendments chiefly sought to remedy a different inequity: differences in property division at divorce and at death (Vernon, 2000, pp. 833-834).

Parliamentary debate on this aspect of the amendments highlighted a perceived tradeoff between the values of justice and expediency. Margaret Wilson (2001, p. 8625) portrayed the 50-50 split as a potentially unjust solution that perpetuated "systemic unfairness", and Matt Robson (2001, p. 8629) argued that the amendments "balance[d] the real impact of the structure of the labour market". National representatives, however, argued that these amendments would provoke litigation, reducing the Family Court's efficiency and exacerbating tensions between former partners at the expense of their families (Ryall, 2001, pp. 8626-8627).

The PRAA also promoted equality between relationship forms by extending the concept of relationship property to de facto relationships (and, following the CUA, to civil unions as well), offering formal protection to de facto partners adversely affected by the division of labour, income and assets in their relationships. This aspect of the PRAA, which combined two bills introduced by National prior to its election defeat, drew fire from National MP Lynda Scott (2001, p. 8632), who sought to preserve marriage as a "different and special status" and the "founding social arrangement of our society". National had proposed a separate but near-equal regime for de facto couples (excluding same-sex couples). Supporters of excluding same-sex relationships argued that, as the bill characterised de facto relationships as relationships in the nature of marriage, including same-sex relationships would be tantamount to recognising same-sex marriage (Kyd, 1998; Schnauer, 1998). Labour's legislation not only treated de facto relationships and marriages similarly, but had also attempted to equalise the status of relationships by dropping references to marriage from the legislation, which were reintroduced following public unease (Tolley, 2001, p. 8630).

The focus on minimising status stratification within the PRA also has implications for relationship entrance. For the Act's purposes, neither marriage nor civil union actually begins at the point of their solemnisation or celebration, but includes any immediately-preceding de facto relationship, marriage or civil union between the couple in question (PRA, 1976, s. 2B2BA). This responds to changing patterns of transition into marriage, but at the expense of assuming that such transitions involve nothing more than a status change, where they may also indicate functional changes. 
De facto partners' rights and responsibilities do remain somewhat differentiated from those of civil union partners or spouses. The Family Proceedings Act 1980 (FPA) provides for the payment of maintenance between formers partners to meet their needs under certain conditions (FPA, 1980, s. 6, 66(2)), yet only spouses or civil union partners have a right to maintenance during their relationship (FPA, 1980, s. 63). The FPA thus assumes that financial interdependence should exist within marriages, but not necessarily within de facto relationships, which clashes somewhat with the role of de facto relationships in the social security system, which presumes that de facto partners are interdependent (Social Security Act 1964, s. 3), allowing the government to reduce its financial obligations.

\section{Separation and dissolution}

The FPA governs the dissolution of marriages and civil unions. At its introduction, the Act altered marriage policy significantly by replacing the grounds under which courts could order divorces with the single, no-fault ground of irreconcilable breakdown, satisfied only by a couple living apart for at least two years, which one or both spouses may prove by producing a separation agreement or separation order (FPA, 1980, s. 39).

Despite its abandonment of pro-traditionalist, fault-based approaches to divorce that require proof of adultery, abandonment, or similar breaches of an idealised form of marriage, the FPA required a mildly interventionist approach for the state. The themes of "reconciliation" and "conciliation" ran throughout, with all legal actors and counsellors involved in relationship disputes called to promote them wherever possible (FPA, 1980 [as enacted], s. 8, 12). Troubled couples could request counselling from the Family Court before entering formal proceedings. The Court had a duty to refer couples to counselling when they applied for separation orders and could adjourn proceedings for counselling when reconciliation appeared possible (FPA, 1980 [as enacted], s. 9-10, 19). The Family Proceedings Amendment Act 1994 introduced sections 12A and 12B, providing public funding for this counselling.

The promotion of reconciliation rests on an assumption that relationships should, ideally, be lifelong, and that genuine public interest exists in fostering this understanding (at an institutional level) and preserving individual relationships (at a personal level). The FPA required a relatively low level of functioning; reconciliation meant only that couples resumed their relationship, and the relationship would thereafter be their private affair. Conciliation, meanwhile, accepts a breakdown in form and attempts to reconstruct a level of function 
sufficient only to settle property and custody matters. By prioritising reconciliation, the FPA sent the message that preserving couple relationships was preferable to splintering and repartnering except in extreme cases.

However, a parcel of Acts passed in late 2013 removed the concept of reconciliation from the FPA. The Family Proceedings Amendment Act (No. 2) 2013 removed the Act's dispute resolution procedures, eliminating the right to free counselling and the responsibilities of professionals to promote reconciliation. This effectively changed the ground for divorce; where the previous system tested whether relationships were actually broken through counselling and legal actors efforts (however superficial), the FPA now assumes that one party's desires and the passage of time are sufficient evidence of irreconcilable breakdown.

Indeed, the new Family Court structure positions parent-child relationships as the only relationships worth protecting. The changes replaced the previous counselling and mediation services with "Family Dispute Resolution", which covers only childcare arrangements and property division (Ministry of Justice, 2014, p. 2). While participants may access some counselling prior to Family Dispute Resolution, this is not relationship counselling as such; rather, its purpose is to help parents to refocus their attention from their relationship to their children.

The National government based its case for focusing on a more limited range of interventions not on ideological aversion to government intervention in relationships, but on administrative efficiency. The regulatory impact statement identified an "urgent" need to lower the costs of the justice system, the unsuitability of some matters for judicial processes, and the "delays and expense" caused by Family Court processes (Ministry of Justice, 2012, pp. 1, 3). The government's focus lay in a target approach that "emphasis[ed] the needs of children and vulnerable people" (Collins, 2013, p. 11536). The Ministry of Justice (2012, p. 9) identified the elimination of relationship counselling as a means of freeing $\$ 9.7 \mathrm{~m}$ for vulnerable cases.

The amendments further the concept that relationships are essentially private affairs rather than expressions of a public institution. National's Scott Simpson (2013, p. 13565) described the changes in language evoking the principle of subsidiarity, arguing that "recourse to State-provided services and facilities should not be a course of first action for people who are going through relationship breakups". The trigger for state intervention is set at a very high level of relationship dysfunction - the level at which there appears to be no 
possibility of the relationship continuing. The National government acknowledges no responsibility to reinforce traditional assumptions of permanence, even on the basis that this might prevent the need for intervention on behalf of children or vulnerable people. The most apparently "conservative" voice in the debate came not from conservative elements of the New Zealand National Party (NZNP) (who could not realistically criticise government legislation, given the strong party unity promoted by MMP), but from Green MP Jan Logie.

"This legislation is what happens when the Government forgets that it has an important role to play in preventing social disintegration." JanLogie (2013, p. 13568) 


\title{
Chapter 5: Australia
}

\section{RELATIONSHIP ENTRANCE AND DEFINITION}

\begin{abstract}
Marriage
The Australian Constitution determines where relationships policy development occurs because it limits the Commonwealth's responsibilities in the area to marriage, divorce, "matrimonial causes", and related childcare matters (Commonwealth of Australia Constitution Act 1900, s. 51(xxi-xxii)). Before the Marriage Act 1961, the states and territories set their own marriage laws which conflicted on matters such as the age of marriage and in some cases prevented indigenous Australians from marrying ${ }^{6}$ (House of Representatives Standing Committee on Social Policy and Legal Affairs, 2012, pp. 9-10). The Marriage Act (like that of New Zealand) controls eligibility to marry and the process of solemnisation (although states have some freedom to govern marriage registration (Marriage Act 1961, s. 6).

The Act originally endorsed the pattern of women marrying younger than men. Women could marry with parental permission at 14 , and without permission at 16 , in each case two years younger than men (Marriage Act, 1961, s. 11-21 [as enacted]).This promoted "traditional" marriage by endorsing a situation in which teenagers with few qualifications and little experience could marry into dependent relationships with older men. The Sex Discrimination Amendment Act 1991 eventually eliminated this discrepancy, and replaced gendered references to "the man" or "the woman" with the generic "1 party". These changes were uncontentious, though their evidential basis is intriguing. Minister Robert Brown ${ }^{7}$ (1991, p. 1416) depicted the change as not simply a matter of correcting discrimination, but as part of a worldwide trend towards a single marriageable age, and acknowledged an Attorney General's department survey of marriage counselling and education professionals as the source of the new age.

\footnotetext{
${ }^{6}$ The Advisory report on the Marriage Equality Amendment Bill 2012 and Marriage Amendment Bill 2012 by the House of Representatives Standing Committee on Social Policy and Legal Affairs (2012, p. 10) found that Victoria's Aborigines Protection Act 1869 allowed the Board for the Protection of Aborigines to refuse the marriage applications of indigenous Victorians, and that Queensland's Aboriginals Protection and Restriction of the Sale of Opium Act 1897 required indigenous women to get permission before marrying a non-indigenous man.

${ }^{7}$ Acting for the Attorney General, Michael Duffy.
} 


\section{Marriage celebrants and solemnisation}

The Marriage Act (pt. IV div. 1) allows people to register as celebrants either in their own right, as civil servants, or as "ministers of religion". The Act presumes that religious leaders put forward by recognised organisations are qualified. The Marriage Amendment Act 2002 refined the appointment of civil celebrants. Candidates must prove that they are appropriately qualified and a "fit and proper person" for the role (Marriage Act 1961, s. 39C(1)). The criteria to prove fitness are a weak form of the priorities of the marital improvement movement (Doherty \& Anderson, 2004, pp. 426-427). Candidates commit to informing couples about relationship support services and engage in professional development (Marriage Act 1961, ss. 39C(2), 29G). Australian celebrants do not yet face the question of whether to celebrate same-sex marriages, but religious celebrants may refuse to solemnise any marriage and impose additional conditions on prospective couples (s. 47). No equivalent privileges exist for civil celebrants.

Civil and religious ceremonies also have different requirements (Marriage Act $1961 \mathrm{s.}$ 45). Religious celebrants may use forms appropriate to their organisation, but civil ceremonies must include a standardised declaration (or variation thereupon) and a statement outlining the nature of marriage. Unless using a Ministerially-approved ceremony, civil celebrants must declare the following or a variation,

... I am to remind you of the solemn and binding nature of the relationship into which you are now about to enter. Marriage, according to law in Australia, is the union of a man a woman to the exclusion of all others, voluntarily entered into for life.

Marriage Act, 1961, s. 46(b)

Civil marriage ceremonies in Australia are not simply the signing of a contract between two people, but act to reinforce the criteria of fidelity and permanence in how the public understands marriage. The words are not only for the exclusive benefit of the marrying couple, but also for those witnessing the ceremony. They attempt to preserve marriage as a particular form of relationship, rather than just a legal status.

\section{Same-sex marriage}

The Marriage Act originally implied that marriage was exclusively heterosexual without explicitly identifying it. The Howard government "corrected" this through the Marriage Amendment Act 2004, which defined marriage as "the union of a man and a 
woman to the exclusion of all others, voluntarily entered into for life" (Marriage Act 1961, s. $5(1)$ ) and prohibited the recognition of foreign same-sex marriages (s. 88EA). The Coalition presented the legislation as a response to the "possible erosion of the institution of marriage" (Ruddock, 2004, p. 31559). It was prompted by other countries' recognition of same-sex marriage, which potentially allowed Australians to contract same-sex marriages overseas and demand that the government recognise them on their return. Although the Australian Labor Party (ALP) supported the legislation, spokesperson Nicola Roxon (2004) argued that the Coalition had manufactured the "crisis". Emerging as an urgent issue - like the American Defence of Marriage Act - in an election year, the Marriage Amendment Act may be seen as electoral populism. However, Murray (2010, pp. 242-244) points out that concern with the erosion of traditional institutions constituted a fundamental element of Howard's political philosophy.

Green senators introduced a series of same-sex marriage bills in response, but none gained parliamentary traction until the 2011 ALP conference voted to endorse same-sex marriage, but allow their representatives to exercise a conscience vote on the matter (Packham, 2011). The conference debate exposed divisions between and within ALP factions, with some same-sex marriage supporters opposing a conscience vote on the grounds that the vote was a matter of "human rights". Catholic "Right" faction members Joe de Bruyn and Hellen Polley argued from a traditionalist perspective to maintain the definition that had "been used for centuries" (ABC News, 2011); de Bruyn suggested that the decision might threaten Labor's chances in marginal seats. ALP MP Stephen Jones introduced a Marriage Amendment Bill in 2012; with a divided ALP and Liberal Party of Australia (LPA) members denied a conscience vote, the bill lost 42-98 in the House.

The Commonwealth's right to regulate marriage prevents policy level-switching in the area. The ACT Labor government, whose Deputy Chief Minister moved the ALP conference motion (Packham, 2011), passed the Marriage Equality (Same-Sex) Act 2013, which mirrored the processes of the Marriage Act 1961 and Family Law Act 1975 (FLA). Tony Abbott's newly elected Coalition government challenged the Act's legality in the High Court of Australia, which deemed it inconsistent with the Marriage Act 1961 (High Court of Australia, 2013) and, in consequence, invalid. 


\section{NON-MARITAL RELATIONSHIPS}

The Commonwealth may regulate non-marital relationships only when the states accord them this power, as the Constitution does not identify it as a subject of federal intervention. New South Wales passed Australia's first de facto relationships protections in 1984. The De Facto Relationships Act 1984 defined the relationships as "relationship[s] of living or having lived together as husband and wife on a bona fide domestic basis although not married to each other", a definition based on social security legislation (Unsworth, 1984, p. 2692)). While courts offered common-law marriages some protection beforehand, the Act attempted to standardise these marriages' treatment and offer some prospect of an equitable distribution of property in the event of a breakdown (Harrison, 1991).

Though other states and territories followed New South Wales with their own de facto property legislation, the treatment of de facto relationships was not standardised until the Rudd government passed the Family Law Amendment (De Facto Financial Matters and Other Measures) Act 2008. Labor avoided explicitly relating de facto relationships to marriage; the Act defined de facto relationships as couples "living together on a genuine domestic basis ${ }^{8}$, established by criteria ${ }^{9}$ almost identical to those of New Zealand's PRA. Australia added state regulation as a possible qualification while omitting "the performance of household duties ${ }^{10}$.

States made a number of changes in how they recognised de facto relationships between 1984 and 2008, shaping and delaying the eventual federal law. A 2002 state Attorneys-General conference agreed to authorise the Commonwealth to legislate on de facto relationship property (Perrett, 2008, pp. 6526-7), as had already occurred for dealing with childcare arrangements. Ex-partners with children were forced to work through two separate court systems to settle their affairs. Policy-makers noted the unsuitability of state courts for de facto property affairs as early as 1991, when a Northern Territory legislator suggested in debating the Territory's de facto property legislation that the Family Court would be the appropriate venue (Hickey, 1991, p. 1385). Despite the dual systems causing unnecessary distress for former couples, and the Howard government's supposed co-operation with the Attorneys-General, the discrepancy remained unresolved throughout the Howard government.

\footnotetext{
${ }^{8}$ The Family Law Amendment Act 1991 which expanded the Family Court mandate over childcare disputes to cohabitants, instituted the "genuine domestic basis" wording, but retained a common-law marriage association (s. 4).

9 Duration, cohabitation, sexual intimacy, "financial dependence or interdependence", property, "mutual commitment", children, and public reputation.

${ }^{10}$ New South Wales and Western Australia included this criterion in 1999 and 2002 respectively.
} 


\section{Same-sex de facto relationships}

The Coalition's unwillingness to introduce promised federal legislation stemmed primarily from opposition to protecting same-sex de facto relationships, rather than opposition to the general concept of de facto relationships. Although most state de facto relationships legislation passed between 1984 and 2008 was championed by Labor governments $^{11}$, many of these bills enjoyed significant Liberal support, and right-wing governments introduced legislation for the Northern Territory and South Australia. In each case, Liberal proponents advocated for clear property division laws primarily on the basis of simplicity - a non-interventionist construction - rather than equality (Manzie, 1991, p. 1058).

The ACT Domestic Relationships Act 1994 provided the first protections for samesex couples. Its proponents did not, however, trumpet it as a revolution in the treatment of same-sex couples. The Act defined domestic relationships as "personal relationship[s] between 2 adults in which 1 provides personal or financial commitment and support of a domestic nature for the material benefit of the other". Thus it identified the functions of care, support and (inter)dependence as worthy of government protection, rather than sexuality. Terry Connolly (1994, p. 1119) argued that his bill would contribute to "equity and convenience", and that restricting "domestic relationships" to de facto heterosexual marriages would "unnecessarily put the issue of sex back in the Bill". Indeed, it passed unopposed, with Liberal concerns directed not towards its potential effects on the institution of marriage, but toward the idea that a broad, functionalist definition might "undermine the spirit of voluntarism (Humphries, 1994, p. 1802).

Three states followed the ACT between 1999 and 2002. New South Wales' Property (Relationships) Legislation Amendment Act 1999 created a broad, functionalist definition of a "domestic partnership" (s. 5), although it retained "de facto relationship[s]" as a subset of domestic partnerships (using the qualifying criteria later adopted by New Zealand and the Australian Commonwealth) (s. 4). Its amendments to other legislation to reconcile the legal position of non-marital relationships and marriages granted some rights to domestic partners generally and in other cases limited rights to de facto partners (often by including them within the definition of "spouse").

Queensland and Victoria protected same-sex de facto couples in 1999 and 2001 respectively. Both changes determined the existence of a relationship on whether two people

11 New South Wales (1984, 1999), Victoria (1987, 2001), ACT (Labor minority, 1994), Queensland (1999), Western Australia (2002), Tasmania (1999, 2003), the Northern Territory (2003/4) and South Australia (2006) 
lived together "on a genuine domestic basis", although Queensland's Property Law Amendment Act 1999 used the term "de facto spouse", while Victoria's Statute Law Amendment (Relationships) Act 2001 used "domestic partner". Neither bill was presented as desexualising the issue of relationship recognition (as in the ACT); the Queensland AttorneyGeneral argued that there was a need to specifically protect same-sex couples (Foley, 1999, pp. 6283-4). The Queensland bill earned partial Liberal support, but National and One Nation MPs argued against treating homosexual and heterosexual relationships identically, though they could support de facto protections as a means of "recognis[ing] social reality" (Springborg, 1999, p. 6260). One Nation's William Feldman (1999, pp. 6276-6277) portrayed the inclusion of same-sex couples as part of a "spiritual war", ruining "otherwise good legislation".

These developments, when considered in the light of John Howard's personal opposition to protecting homosexual couples, provided an obstacle in the path of federal recognition of de facto relationships. Abjorensen (2008, pp. 74-75) points out that the LPA relies more heavily on its leadership than the ALP in setting a policy direction because the ALP pledge requires its representatives to vote for the party platform. The Liberal leader's position is simultaneously more vulnerable because they are selected solely by their caucus. Abjorensen argues that Liberal leaders consequently avoid raising internally divisive issues. While the LPA theoretically supported protecting heterosexual de facto relationships (Blanchfield Nicholls Partners, 2008), raising the issue would put the government in the position of actively discriminating against same-sex couples, rather than simply offering continuity from state legislation. Moreover, as state Liberals were split on the issue, and the National Party (NPA) opposed recognising same-sex relationships, Howard could not readily propose either an exclusive or inclusive definition without provoking division within the Coalition.

By the time Labor eventually introduced the Family Law Amendment (De Facto Financial Matters and Other Measures) Act 2008, every state and territory protected same-sex couples, essentially neutralising conservatives' opportunity to depict including same-sex couples as social engineering. Consequently, opponents expressed general platitudes of support for de facto (and, indeed, same-sex) couples, but also depicted marriage as the “ideal" relationship (Morrison, 2008, pp. 6512-6513). Despite endorsing marriage as the "most secure" environment for raising children, Pentecostal Liberal MP Scott Morrison could also endorse protections for de facto couples in the interests of children by citing a dramatic 
increase in out-of-wedlock births (Morrison, 2008, p. 6514). Opposition representatives did, however, find an issue of contention in the new sections 79(10)(aa) and $90 \mathrm{SM}(10)$ (d) of the FLA, which accord de facto partners the right to become parties to matrimonial proceedings involving their partner and vice versa. Liberal MPs argued that the bill would diminish married people's rights while protecting infidelity and de facto polygamy (Bishop, 2008, p. 6522; Morrison, 2008, pp. 6516-6517).

\section{Registered relationships and civil unions}

A second trend in state-level policy-making - towards allowing various models of opt-in non-marital relationships - did not obstruct federal recognition of de facto relationships. In the absence of an alternative, opt-out path, registered relationships provide diminished protection for vulnerable de facto partners, as relationship rights are contingent on their partner's willingness to enter and remain within the legal relationship, regardless of the reality of the lived relationship. The dual-path approach pioneered by the Tasmanian Relationships Act 2003 retains the protective element of the opt-out approach, while allowing partners to guarantee their legal standing through registration.

Registered relationships or civil unions are currently available in the ACT, New South Wales, Queensland, Tasmania and Victoria, but the process of entering the relationship differs in each state. Tasmania and the ACT allow couples to mark their relationship with a formal ceremony (BDM Tasmania, 2014; Office of Regulatory Services, 2013). The ACT originally attempted to create civil unions in 2006, but was blocked by the Howard government (AAP, 2006), which considered civil unions too similar to same-sex marriage. While the Rudd-Gillard government lifted this ban, allowing the ACT to pass its Civil Union Act 2012, LGBT rights activists believed that the ALP pushed the ACT and New South Wales to "water down" ceremonial aspects of registered relationship and civil union formation to make them appear less marriage-like (Croome, 2010). Queensland's Labor government passed the Civil Partnerships Act 2011 on a conscience vote (Liberals voted en bloc) (Hurst, 2011), allowing couples to mark their relationships with a ceremony, and requiring the same standard of irreconcilable separation as marriage (Civil Partnerships Act, 2011, 18 [as enacted]). The following year, however, the newly-elected Liberal government deceremonialised these partnerships, renamed them as registered relationships (Hurst, 2012), and removed the court process to end the relationship (Civil Partnerships and Other Legislation Amendment Act, 2012, s. 16). The government could argue that they were 
protecting the uniqueness of marriage, while not dramatically eroding the rights of those already in civil partnerships, as might have been the case had they simply abolished the status altogether.

\section{RELATIONSHIP EXIT}

The Family Law Act 1975 covers all matters connected to relationship termination for which the federal government takes responsibility, including divorce, maintenance and property division. States and territories that offer alternative formal relationships have their own systems for dissolving these relationships, though the consequences are usually dealt with through the federal system.

\section{Separation and dissolution}

Part VI of the FLA governs separation and divorce ("divorce" replaced "dissolution" in 2005 to “increase[e] the public's understanding” of the issue (Ruddock, 2005, p. 127)). The Act instituted exclusive no-fault divorce, similar to that of New Zealand. The Commonwealth followed South Australia and Western Australia in introducing divorce on the basis of long-term separation in 1959 with the Matrimonial Causes Act, but as one of a number of grounds (Finlay, 1974, p. 88). The sole ground for divorce under the FLA is that a marriage "has broken down irretrievably" (s. 48(1)), for which the only possible proof is that the spouses have ceased cohabitation for at least a year (s. 48(2)), and there is no "reasonable likelihood" of this changing.

Exclusive no-fault divorce has enjoyed broad support since its introduction. Although Liberal MPs, including John Howard, attempted to amend the Family Law Bill to require a two-year separation and acknowledge the central role of marriage in society (Murray, 2010, p. 243), subsequent Liberal governments have not extended the period. John Bradford (later sole representative of the Christian Democratic Party) accused government policy settings of abetting divorce while debating the Family Law Reform Bill 1994 [No. 2] ${ }^{12}$. Rather than advocating fault-based divorce, however, Bradford focused on the welfare and tax systems, arguing that the welfare systems made living independently too easy for separating spouses, and that the tax system disadvantaged traditional, single-earner families (Bradford, 1994, pp. 2884-2885).

\footnotetext{
${ }^{12}$ Passed as the Family Law Reform Act 1995.
} 
The FLA originally funded marriage counselling organisations to promote reconciliation. Married people could request these services before taking legal action (s. 1516 [as enacted]), and judges could halt divorce proceedings to require couples to attend counselling when reconciliation might be possible (s. 14 [as enacted]), reinforcing the principle that marriage should be lifelong. While reconciliation remains present in the Act, its importance has diminished considerably relative to conciliation.

The Courts (Mediation and Arbitration) Act 1991 and Family Law Reform Act 1995 began this trend, introducing mediation and arbitration to promote agreement between spouses on property issues Courts (Mediation and Arbitration) Act, 1991, s. 4) and childcare issues (Family Law Reform Act, 1995, s. 4), and extended the definition of counselling to cover family and child counselling in addition to marriage counselling (Family Law Reform Act, 1995, s. 4). These changes treated divorce as an acceptable, manageable outcome for the first time. Bradford (1994, p. 2887) interpreted the introduction of mediation as a destructive move, intended to "help [couples] further the cause of breaking up their relationship" at the expense of reconciliation. ALP representative Roger Price (1994, p. 2889) shared this disappointment, having been impressed by New Zealand's Family Court procedures on a tour.

The trend towards conciliation rather than reconciliation continued under the Howard government with the Family Law Amendment (Shared Parental Responsibility) Act 2006. Section 36 eliminated couples' ability to pre-emptively request marriage counselling services as part of a substantial review of the system to allow it to deal more efficiently and effectively with issues around childcare. Under FLA s. 13B, however, the court must still adjourn proceedings and refer couples to counselling where reconciliation appears possible.

The 2006 amendments refocused the FLA on out-of-court conciliation through Family Relationships Centres and Family Dispute Resolution. Then-Attorney-General Philip Ruddock argued that Family Relationships Centres - independently-run, governmentfinanced relationship services hubs - would become "the first port of call for when people need help to make their relationships stronger or when relationships end" (AAP, 2005). Van Acker (2008, p. 104) and Chappell \& Costello (2011, p. 639), however, observe a different motivation behind the changes, arguing that they were primarily a response to the dissatisfaction of men's rights activists with allegedly discriminatory custody decisions. The government itself expressed concern that the community would regard Family Relationships Centres as "divorce shops", simply helping couples to divorce more cheaply and quickly, 
rather than supporting relationships at all stages (Attorney-General's Department, 2010, p. $50)$.

\section{Property division}

Parts VIII and VIIIAB of the FLA deal with the financial implications of separation for married and de facto couples respectively. The original Act provided a consistent property regime for married couples across Australia, but forced unmarried couples to rely on common law or, following the passage of de facto property laws at the state and territory level, on these highly variable laws. This exacerbated power imbalances in financially-uneven nonqualifying relationships, as financially-dominant partners could disempower their partners by threatening to withdraw their support.

Sections 72-77A govern spousal maintenance, which the law views from a functionalist perspective, rather than as an inherent right deriving from the "married" status. The 'right' to maintenance is conditional both on the ability of the supporting party to provide maintenance, and on the supported party having a 'legitimate' reason for being unable to support themselves. While the chief bases for maintenance are childcare and incapacity for employment (s. 72(1)(a-b)), courts may consider a range of other factors including how the marriage has affected the supported party's ability to provide for themselves. One of these factors, section $75(2)(1)$, protects the male breadwinner model by identifying a "need to protect a party who wishes to continue that party's role as a parent". This wording, implemented by the Family Law Amendment Act 1983, replaced the original gendered protection for a woman wishing "only to continue her role as a wife and mother" but, given that childcare remains highly gendered within marriages, it largely retains the protraditional effect of the original.

Prior to 2008, many de facto partners still had either no right or a diminished right to maintenance. New South Wales and ACT relationships legislation offered more limited grounds for maintenance than the FLA (Property (Relationships) Act 1984 [NSW], s. 27; Domestic Relationships Act 1994 [ACT], s. 19). They did not provide for a "reasonable standard of living", compensate for the impact of a de facto relationship on a partner's earning capacity, or protect somebody wishing to continue their parental role (FLA, 1975, $75(2)(\mathrm{g}, \mathrm{k}, \mathrm{l})$ ). Victoria (prior to the Relationships Act 2008) and Queensland did not recognise any right to maintenance. Standardising the entitlement of de facto couples to 
maintenance provided a key motivation for Labor MPs in supporting Commonwealth protections for de facto couples (Neumann, 2008, p. 6519).

The Australian matrimonial property regime makes no effective distinction between relationship property and separate property, and no distinction between different categories of property (home, chattels, and other property in the New Zealand regime); all the property belonging to either spouse can be considered matrimonial property (FLA, 1975, ss. 78-79). It does not assume equal division of property; while an order must be "just and equitable" (s. 79(2)), this relates to each partner's contributions, whether in financial or non-financial terms, to the development of their property, and to the "welfare of the family", as well as the effects of division on the wellbeing of the spouses and their children, and the criteria for maintenance outlined in s. 75(2).

The Family Law Amendment (De Facto Financial Matters and Other Measures) Act 2008 created Part VIIIAB as a mirror of Part VIII. Whilst Part VIIIAB is significantly more complex on paper than Part VIII, these complexities are of little significance in practice (they relate to the need to incorporate the concept of participating jurisdictions). However, despite the general correspondence of the two regimes, there are a handful of subtle differences that reflect different expectations of permanence and commitment between marriage and de facto relationships.

Firstly, while there are no restrictions on the access of married couples to the matrimonial property regime, de facto couples cannot automatically access the de facto property regime. To qualify, they must satisfy the Family Court either that their de facto relationship has lasted two years, that they have a child together, that they have registered their relationship in a state where that is possible, or that denying them access would perpetrate "serious injustice" (s. 90SB). The de facto regime also lacks an equivalent of section 79(1B) (introduced in 1983), which allows the court to adjourn property proceedings other than where a divorce action is imminent, ongoing, or completed, to "consider the effects... of an order... on [their] marriage or the children of [their] marriage". Under this provision, preserving the health of a marriage takes precedence over the desires of the individuals involved for a prompt, equitable division. Reserving this provision exclusively for the matrimonial property regime upholds the idea that marriages are worth more than de facto relationships and reinforces the idea that the state, consequentially, has a duty of care for marriage. It also positions mutual control over marital resources, rather than "independent" control of personal resources, as part of the correct ordering of marriage. 


\section{OTHER INITIATIVES}

\section{Stronger Relationships}

While the Abbott government elected in 2013 has not attempted to alter divorce law, it has nevertheless identified divorce as a core social problem in which government intervention is necessary. The "Stronger Relationships" programme, first proposed by the Coalition in opposition in 2010 (Maley, 2013), and implemented from July 2014, offers a $\$ 200$ voucher for couples to use with an approved relationship services provider (Department of Social Services, 2014). Although its champion, Kevin Andrews - who, with his wife, has worked as a marriage educator - conceived of the scheme as being primarily about premarital education (Penberth \& Andrews, 2014), it is theoretically open to all interested couples, regardless of relationship form.

The scheme moves subtly away from the non-interventionist consensus around relationship breakdown, accepting that government has a role to play - however minor - in preventing breakdown during relationships, rather than trying to mend broken relationships or deal with their consequences. Rather than argue that reducing the incidence of divorce is important solely from a moralist perspective, Andrews argues that the cost of divorce (for which he has suggested figures ranging from $\$ 3$ to $\$ 15$ billion dollars a year) makes intervention necessary (Bearup, 2014; Penberth \& Andrews, 2014). Making this economic case - and making the scheme open to all couples - allows the government to claim that the scheme is more than an attempt to impose traditionalist values by propaganda. The economicrationalist approach also serves to defend the scheme from criticism (e.g. Leaver, 2014) that it is an extravagance in a period of drastic budget cuts. There is a clear difference on this issue between the approaches of the Australian Coalition government and the New Zealand National government, which did not consider the wider economic impact of divorce in its decision to defund court-based relationship counselling.

\section{Strengthening Families}

The Stronger Relationships programme hearkens back to a previous Coalition initiative, the Strengthening Families Strategy, an explicitly pro-traditionalist programme that depicted the promotion of male breadwinner families as a legitimate liberal objective through the language of "choice" (Whitehouse, 2004, pp. 379-380). The Strategy included funding for relationship education, but also provided tax advantages for families with children, 
focusing on single-income families in particular. As originally conceived in 1996, the Family Tax Initiative allowed single-income families to earn an extra $\$ 2,500$ tax-free (Costello, 1996). Howard construed advantaging single-earner families as support for families' own choices, rather than a government agenda to create more male-breadwinner families (Murray, 2010, p. 246). While the single-earner advantage has changed in structure to a means-tested allowance, Family Tax Benefit B (FTB-B) (DHS, 2014a), and is available to de facto partners as well as single parents and married couples, it remains a core element of Australian family policy for the time being. The benefit's eventual downfall may lie in fiscal constraints rather than changing social attitudes; while the Howard government steadily increased the level of FTB-B (Liberal-National Coalition, 2004, pp. 5-6), the 2014-15 Budget restricts eligibility for FTB-B to parents of under-6s as part of the Abbott government's cost-cutting agenda. 


\section{ChaPTER 6: UNITED STATES}

American relationships policies are primarily the responsibility of the states rather than the federal government. States register marriages and are responsible for policies on divorce, de facto relationships, and civil unions. The federal government is involved in relationships policy through the tax and welfare systems, and in funding marital support services.

\section{RELATIONSHIP ENTRANCE AND DEFINITION}

\section{MARRIAGE}

\section{Defining marriage}

There is considerable variation between states in how marriage is defined and contracted. Same-sex marriage has been the most significant issue in marriage definition between 1990 and 2014. Before 1993, states usually assumed that marriage was exclusively heterosexual without explicitly stating it. Oklahoma, for instance, defined marriage only as "a personal relation arising out of a civil contract" with associated requirements for consent (Oklahoma Statutes (OKS) §43-1). Hawai'i did not define marriage, but did regulate it in gendered language referring to "the man and the woman" (Klingerman \& May, 1994, p. 449). In 1993, however, a group of same-sex couples won a partial victory in the Hawai'i Supreme Court, which required the state to provide a "compelling state interest" for denying them marriage licenses (Klingerman \& May, 1994, pp. 447-448). The court suggested that the state had violated its constitution by discriminating on the basis of sex (Cox, 1994, p. 1051).

This created a "crisis" for every other state, because the "Full Faith and Credit" section of the Constitution of the United States (Art. 4, §1) requires each state to recognise other states' "acts, records, and judicial proceedings". Same-sex couples married in Hawai'i might require the federal government and other states to recognise their marriage (Cox, 1994, p. 1040). Hawai'i responded initially by inserting a clarification that only opposite-sex marriages were valid, but the court deemed this insufficient (Bowman, 2004, p. 135). The state eventually satisfied the court by implementing a "reciprocal beneficiaries" scheme that reduced the inequalities caused by denying same-sex marriage, and amending its constitution by referendum in 1998 to permit the legislature to prevent same-sex marriages. 
The Hawai'ian debate also triggered federal action to forestall the potential effects of the "Full Faith and Credit" clause. The Defence of Marriage Act of 1996 (DOMA) asserted states' right to ignore same-sex marriages registered elsewhere and prevented the federal government recognising same-sex marriage. Senate Majority Leader Trent Lott (1996, p. S10101) argued that the "Full Faith and Credit" circumvention was necessary to defend the country from a "handful of judges", and that allowing same-sex couples equal access to federal programmes would have severe "financial and social consequences". DOMA opponents, while not necessarily endorsing same-sex marriage (and occasionally asserting their opposition), portrayed it as unconstitutional and "mean-spirited" (Kennedy, 1996, p. S10101; Kerry, 1996, p. S10108). Despite its uncertain constitutionality, DOMA received veto-proof majorities in both chambers; a clear majority of Democrats and a near-unanimity of Republicans supported the bill (of Republicans, only openly-gay Steve Gunderson dissented) (GovTrack, 2014a, 2014b).

A wave of state-level action occurred in conjunction with DOMA; a majority of states passed local versions of the federal law (Pinello, 2006, p. 33). This included the additions of OKS §43-3.1 in 1996 and Arkansas Code $\$ 9-11-109$ in 1997. Despite traditionalists' legislative success, same-sex marriage supporters used the judicial system as an alternative venue, less susceptible to popular opinion. Vermont's Supreme Court found in 1999 that the state constitution required Vermont to provide equal benefits to same-sex couples (Charron, 2000). However, as the court did not require Vermont to provide same-sex marriage, the legislature developed civil unions as a compromise.

Massachusetts same-sex marriage supporters won a similar case in 2003, again based on a state constitution equal protection clause, but the courts refused to accept anything other than same-sex marriage (Pinello, 2006, pp. 43-44). The Massachusetts Senate President ignored a petition at the state Constitutional Convention for a referendum on the matter (Pinello, 2006, p. 36), forcing same-sex marriage opponents to pursue a longer process, by the conclusion of which same-sex marriage was well established.

The Massachusetts decision triggered another flurry of state action in the form of state constitutional amendments. Eleven states passed constitutional bans on same-sex marriage in 2004, with support ranging from 57\% in Oregon to $86 \%$ in South Carolina (CNN, 2004). However, these actions have only delayed the introduction of same-sex marriage. Same-sex marriage advocates excluded from state courts by constitutional amendments have turned to the federal constitution and courts instead. Californian voters banned same-sex marriage in 
2008 following campaigning by a coalition of religious groups (The Economist, 2008a, 2008b). While the state Supreme Court upheld this ban, federal courts ruled it unconstitutional on the basis that it violated the federal constitution's equal protection clause (Nagourney, 2012). Subsequent decisions in other states have eliminated bans on same-sex marriage on similar grounds (Barnes, 2014; Stutzman, 2014) and found DOMA partially unconstitutional (GLAD, 2013).

State legislatures have become increasingly viable options for same-sex marriage advocates. Polling suggests that American attitudes to same-sex marriage have shifted considerably (McCarthy, 2014), reducing the potential electoral penalties for legislators who endorse same-sex marriage, and making constitutional amendments more difficult for conservatives. In 2009, Vermont became the first state to choose to adopt same-sex marriage (Richburg, 2009). Same-sex marriage advocates now have three levels of opportunity, and need only succeed at one to achieve their goal, while their opponents must win at each level.

\section{Age of marriage}

The age of consent to marriage has changed surprisingly little in the US. While the age of non-restricted consent is at least 18 throughout America, and marriages of those aged 16-17 usually require parent permission, many states have no absolute minimum age (Leiter, 2008, pp. 463-468). This is not necessarily due to a lack of attention to legislative minutiae. In 2004, Oklahoma simplified the language in OKS $\S 43-3(\mathrm{~B})(2)$, which allows courts to permit anybody under age 16 to marry "in settlement of a suit or seduction or paternity" or when the bride is pregnant or has given birth. Low minimum ages have persisted despite evidence that early marriages fail at considerably higher rates than adult marriages (Le Strat, Dubertret, \& Le Foll, 2011, p. 530), and despite the federal government funding research into eliminating child marriage overseas (Jain \& Kurz, 2007). 
Figure 1: Absolute minimum ages of marriage in the United States
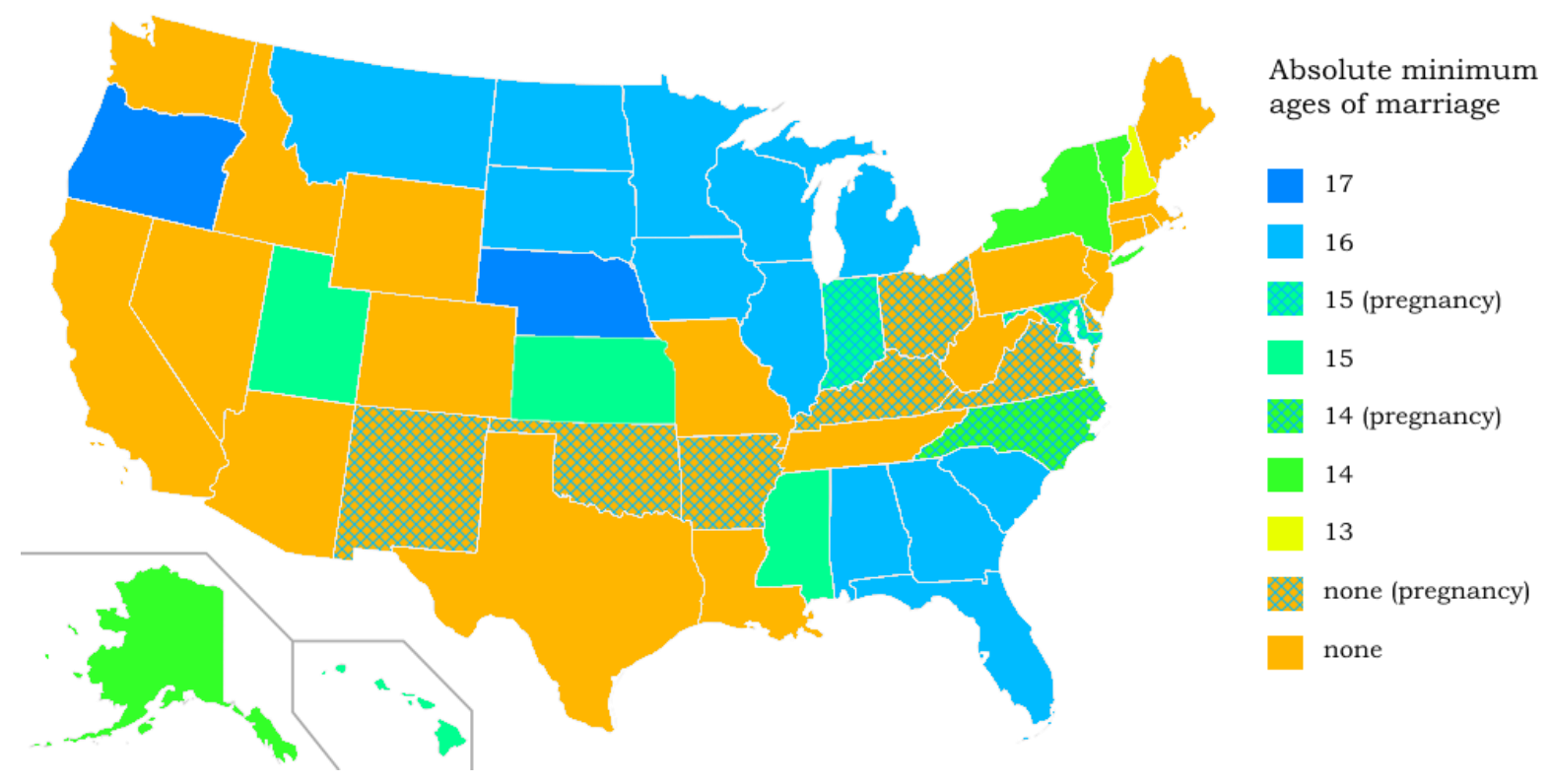

Sources: Leiter (2008, pp. 463-368); Kansas Statutes \$23-2505

\section{Marriage celebrants and solemnisation}

American marriage celebrants are either civil or religious celebrants. Most American civil celebrants derive their authority from their standing in the legal system, rather than as community representatives as in Australia and New Zealand. Oklahoma allows only active or retired judges (OKS §43-7), while Louisiana and Hawai'i include justices of the peace and magistrates respectively (Hawai‘i Revised Statutes (HIRS) §572-12; Louisiana Revised Statutes (LARS) 9§203), and California authorises State and Federal legislators (California Family Code (CAFC) §400).

This is not always strictly the case. Vermont allows people to register to celebrate individual weddings (Vermont Statutes 18§5144a), while New Jersey allows people to qualify as civil celebrants by completing a course (an individual-merit rather than community-representation basis for celebrancy) (New Jersey Statutes 37§1-13). Otherwise, secular celebrants may qualify as "clergy" through authorisation by groups such as the Humanist Society (2013, p. 13). Nevertheless, restricting civil solemnisation rights in most cases to judicial professionals emphasises an understanding of marriage as a contract, rather than a commitment embedded in the community. Strow \& Strow (2006, p. 241) point out that, in early New England, marriage was entirely the domain of the judiciary rather than clergy, in order to emphasise this (Protestant) contractual understanding over a (Catholic) sacramental understanding. 


\section{Covenant marriage}

Three states, beginning with Louisiana in 1997, have experimented with allowing couples to contract "covenant marriages". These restrict divorce options, theoretically requiring couples to demonstrate a stronger commitment to their marriage. Covenant spouses agree to "love, honor, and care for one another as husband and wife for the rest of [their] lives” (Arizona Revised Statutes (AZRS) §25-901(B)(1); Arkansas Code §9-11-804(a)(1); LARS 9\$273(A)(1)). While the effects of covenant marriages vary between states, the bulk of this declaration transferred wholly from Louisiana to Arizona and Arkansas, and to proposed legislation such as the 2004 SB882 in Oklahoma (proposed OKS §43-6.1).

Covenant marriage schemes allow states to require forethought from prospective spouses. Couples undergo premarital counselling from either a religious minister or relevant professional (LARS 9§273(A)(2), 9\$275(C)(1)(b). This allows the state to reinforce the understandings of marriage favoured by legislative and religious elites without coercively interfering in married couples' lived relationships. Covenant marriage schemes have minimal practical effect. In Louisiana, where they are most popular, only $2 \%$ of marriages are covenant marriages (National Healthy Marriage Resource Center, 2010, p. 3).

Attempts to introduce covenant marriages elsewhere have failed. National social conservative organisations such as Focus on the Family and the Family Research Council that organise against policies such as same-sex marriage have not supported individual legislators' efforts (despite the instigator of covenant marriage in Louisiana heading the Family Research Council) (M. A. Smith, 2010). Some conservatives disagree in principle with offering multiple forms of marriage (Nock, Wright, \& Sanchez, 1999, p. 45). The Catholic Church criticises covenant marriage as depicting other marriages as inferior (National Healthy Marriage Resource Center, 2010, p. 2), while the President of Concerned Women for America (CWfA) suggested that it also allowed too many loopholes (Pate, 1998)

Feminist organisations, however, do organise against covenant marriage. Nock et al. (1999, p. 47) found concern amongst Louisianan feminists that religious leaders would use premarital education to promote traditional gender roles. The Kansas National Organisation for Women argued in a hearing that the model proposed there would impose unjust financial burdens on women seeking divorce, potentially trapping them in dangerous marriages (Rinker, 2010). Curiously, this submission also echoed conservative rhetoric from the same- 
sex marriage debate, accusing the initiative of "allow[ing] special interests to continually redefine matrimony in our state".

\section{Alternative premarital schemes - licenses as policy}

Other states promote premarital education to all couples. Texas Republicans linked premarital education to license issuance in 1999 in an attempt to reduce the divorce rate (Office of House Bill Analysis, 1999). Clerks must inform couples about premarital education opportunities (Texas Family Code (TXFC) $\$ 2.009(\mathrm{c})(5)$ ). Couples are excused part of their license fee on completion of a course covering "conflict management,... communication skills... and the key components of a successful marriage", conducted through a religious or community organisation or private professional (TXFC \$2.013; Texas Health and Human Services Commission, n.d.). Otherwise, the state uses part of this fee to develop low-cost premarital courses and research into family strengthening (TXFC $\S 2.014(\mathrm{~b})$ ). The committee process, which involved family professionals (Juvenile Justice \& Family Issues Committee, 1999), minimised its pro-traditionalist character. The original bill required, rather than incentivised, participation (Office of House Bill Analysis, 1999).

Another group of states uses the licensing process to mitigate the consequences of relationship disharmony. In 1997, Hawai'i established funds, part-financed by marriage license fees (HIRS §572-5), to support domestic abuse programmes (State of Hawai'i Department of Health, 2010; HIRS §346-7.5, §601-3.6). This tactic, focusing primarily on the most extreme consequences of relationship breakdowns rather than their prevention, reflects an essentially non-interventionist approach. Hawai' $i$ also uses the license issuance process to supply couples with information about issues such as birth defects and STIs ${ }^{13}$ (HIRS $\$ 572-$ 5(d)), as does California (CAFC §358). Despite marriage not being seen in these states as a necessary prerequisite for childbearing, it remains a key point of contact.

\section{NON-MARITAL RELATIONSHIPS}

Bowman (2004) identifies five approaches that states use to deal with relationships outside conventionally-contracted marriage: common-law marriage; relationship contracts; civil unions or domestic partnerships; assigning particular rights to cohabitants; or not recognising non-marital relationships. Common-law marriage, once commonplace, is now restricted to a handful of states. Civil unions and domestic partnerships have developed

13 Intriguingly, HIRS $\$ 572-5(\mathrm{~d})$ requires agents to also supply information on "population stabilization", suggesting an anti-natalist agenda. 
recently as a hedge against same-sex marriage. The rights accorded to cohabitants have increased incrementally in response to perceived injustices.

Common-law spouses are recognised as equal to formally-married spouses, and their rights are recognised throughout America. However, entrance to common-law marriage is increasingly restricted. Merriman (2007) attributes the historical importance of common-law marriage to the isolated nature of many American settlements until relatively recently; improved access to government removes the need for informal marriage. Four states ceased recognising new common-law marriages between 1990 and 2005, leaving ten states remaining. In Pennsylvania, change was not driven by pro-traditionalist qualms about common-law marriage, but by pragmatic concerns over the uncertainty of their existence and the potential for "fraudulent attempts to win death benefits" (Toland, 2004). Texas attempts to avoid uncertainty by allowing couples to legally declare their "informal marriage", without which the relationship's existence may be called into question (TXFC §2.401).

Domestic partnerships originally developed at the local government level. San Francisco established a partnership registry in 1989 (Bowman, 2004, p. 134), before California adopted partnerships in 1999 (Batten, 2010). Local authorities' limited capacity meant that early domestic partnerships could convey only limited benefits, principally to these authorities' employees (Bowman, 2004, p. 134). Because civil unions developed in Vermont as a functionally equal counterpart to marriage, they carried far greater legal rights from the start (Goldberg, 2000). Civil unions and domestic partnerships are usually restricted to same-sex couples, although California and New Jersey allowed elderly heterosexual couples to access the status (to protect their children's inheritance rights ${ }^{14}$ ), and Hawai ' $i$ allowed legally-unmarriageable heterosexual couples to become "reciprocal beneficiaries", effectively desexualising the policy (Bowman, 2004, pp. 135, 137).

Domestic partners' rights vary considerably. California partners' rights were initially limited, but were expanded by legislation in 2003 to be essentially equivalent to marriage (Traiman, 2008). Washington similarly expanded domestic partnership rights in 2009, two years after introducing the status (La Corte, 2009). Following Washington's adoption of same-sex marriage, domestic partnerships of couples under 62 are being converted to marriage (Washington Secretary of State, 2014). A state constitutional ban in Wisconsin on

\footnotetext{
${ }^{14}$ In this situation, the lack of recognition of non-marital relationships by the federal government worked in these couples' favour. Married or divorced people who are not entitled to receive Social Security retirement benefits in their own right may access these through their spouse or former spouse. Remarrying, however, could cause a divorced person to lose these benefits (Bowman, 2004, pp. 135).
} 
according homosexual relationships a status similar to marriage means that the domestic partnership regime offers a limited selection of rights (Ferguson, Stein, \& Silverstein, 2014).

State recognition for de facto relationships is more limited. Cohabitants must usually make a contract to expand their rights against each other beyond those of legal strangers (Bowman, 2004, pp. 126-127), and judges in Illinois, Georgia, and Louisiana ignore contracts between cohabitants. In Washington, separating couples are subject to property division if their relationship is identified as marriage-like, but this identification takes place only after the end of the relationship (Northwest Justice Project, 2010). As a judicial, rather than legislative construction, this "meretricious relationship status" may be somewhat precarious (Wallace, 2005, pp. 253-255). Bowman (2004, pp. 141-142) notes that, beginning as early as 1968, the courts in a number of states have progressively allowed cohabitants to make claims against third parties in cases such as wrongful death, and that local governments regularly cover health insurance for cohabitants. Because many of these rights are essentially at judicial discretion, and may be difficult to access for many cohabitants, the only certain means of securing the full rights accorded to marriage is to marry.

\section{RELATIONSHIP EXIT}

\section{Separation and dissolution}

During the 1970s and 1980s, every American state adopted no-fault divorce ${ }^{15}$ (Wolfinger, 2005, pp. 407-408). Many of their systems operate quite differently from those of Australasia, and a particular state's model may not correspond to its perceived ideological position. Calfornia and Hawai'i use the exclusive no-fault model found in the Antipodes. California allows divorce on the basis of "irreconciliable differences" or "incurable insanity" (CAFC §2310). Hawai“i requires marriages to be "irretrievably broken" or to meet a separation-based qualification (HIRS §580-41).

Another set of states mixes fault and no-fault grounds for divorce. This allows for low-conflict divorces, but also allows aggrieved spouses to pursue an action that labels their spouse as guilty (and in some cases influences property settlements). Oklahoma introduced an "incompatibility" ground early, but also offers nine fault grounds and grounds of insanity (OKS §43-101). Vermont offers no-fault divorces following an irreconcilable six-month separation, five fault grounds and grounds of insanity (Vermont Statutes 15§551).

\footnotetext{
15 Alaska, Maryland and Oklahoma already had no-fault divorce options.
} 
Figure 2: Divorce regimes in the United States

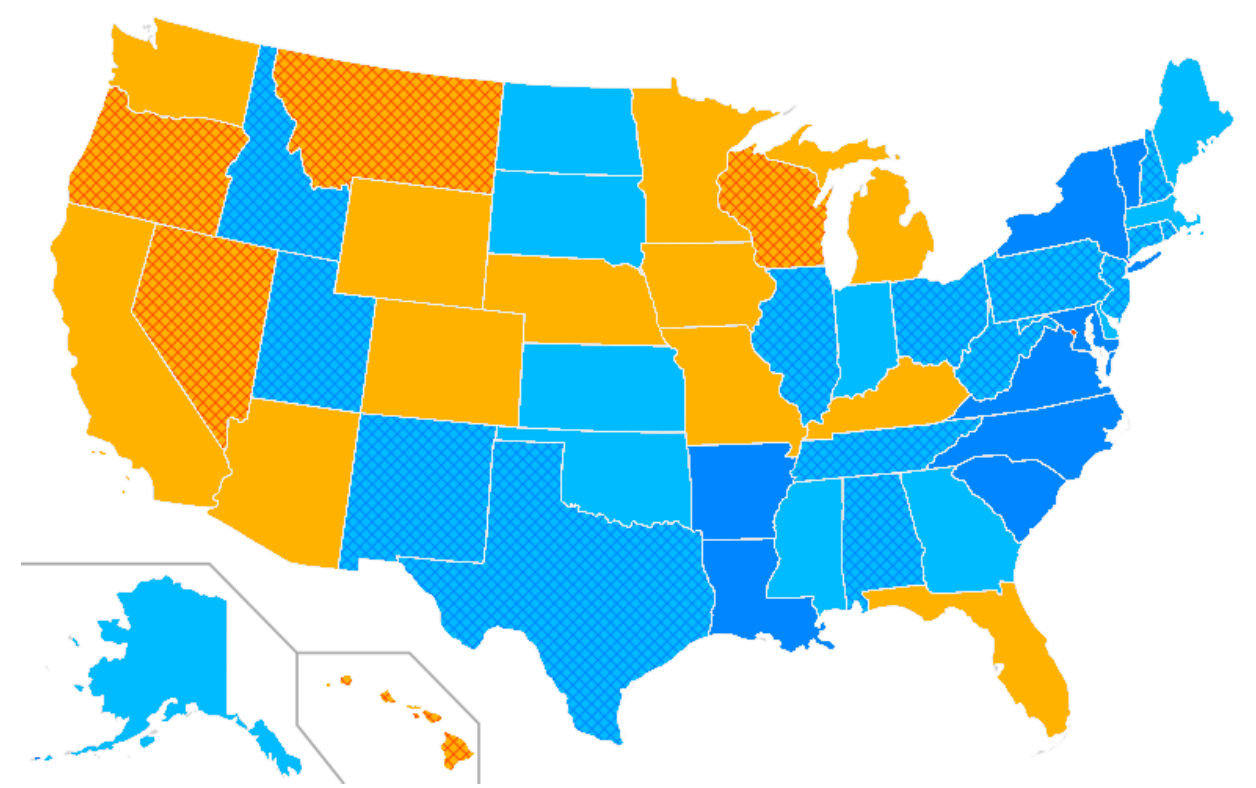

Divorce regimes

Exclusive no-fault (differences)

Exclusive no-fault (differences OR separation Exclusive no-fault (separation)

Non-exclusive (differences) Non-exclusive (differences OR separation) Non-exclusive (separation)

Sources: Leiter (2008, pp. 463-368); New York Domestic Relations Code \$170

The Vermont law reflects the curious reality that the American North-East, despite its liberal reputation, emerged from the no-fault reform period with non-exclusive divorce models (Simmons, 1998, p. 7). New York introduced a truly unilateral no-fault option only in 2010. Formerly, divorces were granted only on the basis of four fault grounds, a year-long separation following a judicial separation (granted on a fault basis), or a two-year separation following a separation agreement.

While conservative actors resisted change in this last hold-out, they have made little impact in undoing the no-fault hegemony. Even when successfully implemented, covenant marriage does not dramatically affect the status quo. Louisianan covenant marriages are subject to non-exclusive, separation-based no-fault divorce (LARS 9§306). Arizona's covenant marriage regime allows no-fault divorce not only on the basis of separation, but also by mutual consent (AZRS $\S 25-903(5-6,8)$ ). Covenant marriage’s most substantial barrier to divorce is the requirement for covenant spouses to undergo counselling "once [they] experience marital difficulties" (LARS $9 \S 307(\mathrm{C}))^{16}$.

Broadly speaking, two models of matrimonial property exist in America: community and non-community states. However, these do not translate directly into two models of property division at divorce, because the question of ownership during marriage is

\footnotetext{
${ }^{16}$ Act No. 490 of 2004 amended the 1997 legislation (Act No. 1380) to clarify that reconciliation efforts should continue from a couple's first difficulties to the judgment of divorce, except in cases of domestic abuse.
} 
disconnected from the question of who should own it afterwards. Instead, all American models of matrimonial property division operate on some type of community-basis. Some community property states use a 50-50 split as in 1976-2001 New Zealand, while the remaining states divide property on an equitable basis relating to marital contributions (Oldham, 2008, p. 431).

\section{Ending non-marital relationships}

The process required to end a non-marital relationship relates to the status accorded to the relationship. American civil unions' origins as marriage-by-another-name (Goldberg, 2000) mean that their dissolution processes mirror divorce processes (Student Legal Service, n.d.). However, out-of-state couples who registered civil unions in Vermont could not originally dissolve their relationship without one partner migrating to Vermont for a year as their relationships were not recognised elsewhere (Vermont Freedom to Marry, 2012), potentially leaving partners endangered, financially-trapped, or unable to contract another relationship. This was resolved only in 2012, when Act No. 92 created a process for nonresident couples to dissolve their relationship from elsewhere.

Domestic partnership exit processes have evolved alongside their status. Californian domestic partnerships were initially dissolved outside judicial processes, but when the state accorded greater rights to the relationships in 2005 it also revised the termination process so that only partners with low levels of commitment and interdependency (in terms of duration, children, and property interests) could end their relationships without a full legal process (CAFC §299, 299.3). In Wisconsin, where domestic partnerships retain a sub-marriage legal status, a partner may unilaterally dissolve their partnership with a 90-day waiting period (Wisconsin Statutes \$770-12), while divorces require a year-long separation or judicial ruling of irreconcilability (Wisconsin Statutes $§ 767.315$ ).

\section{Reconciliation and conciliation}

States' roles in promoting reconciliation vary considerably. A number of states, including California and Arizona, established "conciliation courts" in the 1960s to provide marital counselling (Association of Family and Conciliation Courts, 2014). Since the 1980s, these courts have focused primarily on mediating custody disputes, although some reconciliatory efforts remain. Arizonan conciliation courts (which offer most services free) provide reconciliatory counselling alongside their mediation services (Judicial Branch of Arizona Pinal County, 2014; AZRS §25-381.16). Californian family conciliation courts play 
a similar role, and may even attempt to reconcile unmarried couples when children are involved (CAFC §1830). The primarily non-interventionist character of these states' relationship exit regimes stand somewhat in contrast to their mission statements, which declare marital stability to be a legitimate focus of state attention:

The purposes of this part are to protect the rights of children and to promote the public welfare by preserving, promoting, and protecting family life and the institution of matrimony, and to provide means for the reconciliation of spouses and the amicable settlement of domestic and family controversies.

\section{CAFC \$1801; AZRS $\$ 25-381.01$ inverts two clauses}

States that retain a reconciliation focus do not necessarily take full responsibility for achieving reconciliation; California, Arizona and New York involve non-government organisations, including religious groups, in the process (New York Family Court Act §923).

An alternative approach, practiced in Vermont, is to allow courts to stay proceedings for potential reconciliation without providing practical support for achieving it (Vermont Statutes §15-552). Even this provision is limited to no-fault cases; fault-based divorces provide no opportunity for courts to pursue reconciliation. Vermont does, however, provide limited support for conciliation on property and custody matters, promoting and subsidising mediation services for low-income couples (Vermont Judiciary, 2007) and working with a local university to provide separation education for divorcing parents (University of Vermont, 2014).

Voluntary counselling may function to expedite divorce in Oklahoma. Courts may waive post-filing waiting periods intended to provide an opportunity for reconciliation if counselling is unproductive (OKS §43-107D). Oklahoman parents referred to mediation or counselling on custody matters bear the costs themselves (OKS §43-107.3). Otherwise, Oklahoman family courts provide only limited educational resources (Tulsa County District Court, 2014). Although Vermont countenances somewhat more public support for preserving family function through relationship transitions, these states without dedicated (re)conciliation courts broadly follow a model that sees preserving relationships as the domain of the individuals involved. State involvement in the marital relationship focuses on the care of children. 


\section{THE FEDERAL GOVERNMENT AND MARRIAGE}

While the federal government does not regulate marriage, it nevertheless plays an active role in relationships policy. Federal legislators focus considerable attention on the incentives and disincentives created by federal policies, particularly the interaction of marriage and the tax and welfare systems. The "marriage tax penalty" was a prominent subject of contention toward the end of the Clinton administration and the first Bush administration, leading to significant tax cuts for married Americans. The federal government has also developed a role in directly promoting marriage.

\section{Marriage and the welfare system}

Aid to Families with Dependent Children (AFDC), which provided assistance to poor single parents without imposing onerous behavioural restrictions, formed a significant part of the American welfare system from the 1930s (Berrick, 2005, p. 133), and was regularly criticised as disincentivising marriage (Bitler, Gelbach, Hoynes, \& Zavodny, 2004, p. 213). Legislators from both parties saw the Personal Responsibility and Work Opportunity Reconciliation Act of 1996 (PRWORA) as an opportunity to promote positive work habits and personal responsibility, reduce the federal government's reach, and slow welfare expenditure growth, while "creat[ing] incentives for families to stay together" (Domenici, 1996, p. S9322). PRWORA replaced AFDC with Temporary Assistance for Needy Families, which expanded eligibility for welfare to more married couples while imposing work requirements and time limits (Bitler et al., 2004, p. 216). These changes aimed to reduce the financial penalties created by marrying to make single parenthood less attractive.

PRWORA and its supporters (as well as some opponents) depicted the relationship between AFDC and unwed parenting as a vicious circle. Section 101 proclaimed that "marriage is the foundation... of a successful society which promotes the interests of children" (PRWORA, 1996, §101(1-2)) and included statistics to demonstrate a causal connection between the growth of AFDC and extramarital births (PRWORA, 1996, §101(5-6, 8)). Representatives used these statistics to argue welfare "subsidize[d] and promote[d] selfdestructive behaviour and illegitimacy... and [had] destroyed the family" (Faircloth, 1996, p. S9366). PRWORA also provided a crude incentive system for states to discourage illegitimacy; states that demonstrated a decrease in illegitimate births would receive a significant increase in their "family assistance grant" (PRWORA, 1996, §103). 
Opponents accepted the principle that illegitimacy was a social problem in which the government had a right to intervene. Instead, they objected on the basis that the Act would simply hurt children without having the desired impact on illegitimacy or welfare dependency (Bradley, 1996, p. S9367; Moseley Braun, 1996, p. S9365), or on the principle that "the punishment should never exceed the deed" (Lautenberg, 1996, p. 9324). Despite the importance of conservative ideas about ideal family form in the debate, PRWORA was not an exclusively pro-traditional policy, as it sacrificed traditional understandings of motherhood as the primary role of women. Ultimately, illegitimacy concerns played a secondary role in the debate to concerns about welfare dependency.

\section{Marriage and federal taxation}

The federal tax system creates marriage penalties and benefits by treating married couples differently from single people and unmarried couples. Married couples file taxes either individually or jointly ${ }^{17}$; each option carries particular advantages and disadvantages depending on the economic structure of a marriage. The availability of joint-filing is protraditionalist because it advantages single-earner or dominant-earner couples. When spouses earn close to equal amounts, however, they may be disadvantaged by being married because married people filing singly have lower tax brackets than single people. The tax deduction system is a second factor, as it offers single taxpayers greater "standard" deductions (Brozovsky \& Cataldo, 1994, p. 166). The Earned Income Tax Credit (EITC) contributes to the marriage penalty faced by low-income working families. The EITC phases out as an individual or married couple's income increases, so marriage may eliminate the tax credit that a single taxpayer would otherwise receive (Maag \& Carasso, 2014). Strach (2007, p. 116) identifies EITC as the most significant penalty as a proportion of a couple's income.

While marriage tax penalties still exist for some couples (just as advantages do for others), they were blunted by a Republican-led reform effort in 2000-2001. While the potential for the tax system to punish marriage had existed for a long time, the salience of the problem had increased considerably. Dual-earner marriages peaked in 1996, and wives' contributions to family incomes were steadily increasing (USBLS, 2013, pp. 80-81), so more couples faced potential tax disadvantages. Meanwhile, the increased prevalence and acceptance of cohabitation amongst young couples reduced the non-financial advantages of marriage, creating a need for the government to reward the "right" choice. The issue also 17 Same-sex married couples were not treated as married by the IRS until DOMA was ruled partially
unconstitutional (IRS, 2013). 
allowed Republicans to develop a moral case for cutting taxes to accompany their preferences for smaller government.

The Marriage Tax Relief Reconciliation Act of 2000 (MTRRA) and Economic Growth and Tax Relief Reconciliation Act of 2001 (EGTRRA) sought to reduce the marriage penalty by increasing tax brackets, standard deductions, and the EITC phase-out threshold for married couples. Supporters framed the debate as one about fairness and equity, in which the tax penalty was an invidious attempt to "nickel and dime the American people" (Pryce, 2000, p. H6607). They referred only to marriage penalties, pointing to " 25 million married working couples... [that] pay an average $\$ 1,400$ more in higher taxes just because they are married" (Weller, 2000, p. H6607), framing the tax system as one that treated marriage in a uniformly negative fashion. Democrats opposed to the plan (including President Clinton, who vetoed the MTRRA) accepted the importance of reducing marriage penalties, but argued that the plan was too expensive, and weighted too heavily to the wealthy (Levin, 2000, p. H6612).

The EGTRRA, introduced after the election of President George W. Bush, collapsed marriage penalty relief into a wider programme of "historic tax relief" (Reynolds, 2001, p. $\mathrm{H} 2825$ ). With a president sympathetic to tax cuts, Republicans no longer need to focus on the victimisation of the married to justify cuts; indeed, the EGTRRA placed less importance on reducing the marriage penalty than the MTRRA had. It delayed the elimination of the deduction penalty and $15 \%$ tax bracket and reduced the magnitude of the immediate extension of the EITC threshold (MTRRA [H.R. 4810 enrolled], 2000, §2-4; EGTRRA, 2001, §301-303). Strach (2007, p. 120) points out that Republicans wished to avoid privileging two-earner families over traditional families. Consequently, they adopted broad changes, rather than narrowly addressing dual-earner families' concerns.

\section{Healthy Marriage}

Under George W. Bush, the federal government embarked on a programme of marriage promotion for vulnerable families through both existing and new government programmes. The first such initiative, proposed by the President (Herger, 2001), authorised states to use federal money for family support services to fund services to "strengthen parental relationships and promote healthy marriages". The most significant example, however, is the Healthy Marriage \& Responsible Fatherhood initiative (HMRF), instituted by the Deficit Reduction Act 2005. This replaced the illegitimacy-rewards system of PRWORA, which had focused solely on family form, with a system that, while remaining grounded in 
traditionalist ideas, refocused the government's attention to a greater extent on family function.

In HMRF, the government funds organisations to provide relationship education, marriage skills education, premarital education, parenting skills, and work skills, primarily to high-risk populations (Office of Family Assistance, 2014a, 2014b). While initially proposed by President Bush as part of his "compassionate conservative" agenda (Pear \& Kirkpatrick, 2004), it has continued and expanded under President Obama. The current administration claims that it is developing more culturally responsive programmes to deal with vulnerable ethnic groups (The White House, 2012, pp. 16-17), a timely shift in approach, given that a recent study found that programmes funded through the initiative were ineffective partly because they were based on research that focused on "White, middle-class" couples, rather than on the vulnerable populations that are the intended target of the initiative (Johnson, 2012). 


\section{Chapter 7: Classifying Relationships Policies}

In this chapter I adapt Gauthier's (1996) typology of family policy ideal-types to demonstrate that the different approaches to relationships policy that have emerged in New Zealand, Australia and America are significant. While Gauthier does not use relationships policies in building her typology, the ideological assumptions about how the state should intervene in the family that underlie each ideal-type apply equally well to relationships policy, with the possible exception of "pro-natalism", which is tied particularly to childcare and population policy. Pro-natalism influenced post-1980 marriage policy in Singapore, where the government promoted marriage to encourage child-bearing, However, although Heard (2006) points out that pro-natalism has influenced recent Australian family policy, there is little evidence that this reaches into relationships policy. Pro-natalism may need to be allied to strong sentiments against extramarital childbearing to influence relationships policy. I consequently discuss only the remaining three ideal-types here.

\section{TRANSLATING FAMILY POLICY IDEAL-TYPES TO RELATIONSHIPS POLICY}

\section{Pro-traditionalist model}

Gauthier (1996, pp. 203-204) identifies "pro-traditionalism" as the policy ideal-type in which preserving the traditional, male-breadwinner family form is the central objective of family policy. Although a pro-traditionalist view sees the institution of the traditional family as the best provider of wellbeing, the government may intervene to facilitate this, such as by offering extensive childcare leave for mothers to allow them to retain the primary caregiver role - rather than relying on private sector childcare. Relationships policy provides a number of avenues for governments to accomplish pro-traditionalist objectives, because they may act to safeguard the traditional family at both the institutional and individual levels.

\section{Pro-egalitarian model}

The chief objective of pro-egalitarian family policies is to promote gender equality (Gauthier, 1996, p. 204) by supporting women's participation in paid employment, and men's participation in care work. A somewhat broader definition that acknowledges other forms of discrimination (particularly those based on sexual orientation and ethnicity) may now be 
appropriate. Pro-egalitarianism is essentially diametrically opposed to pro-traditionalism in its objectives, although it may encompass a similar level of government intervention.

\section{Pro-family but non-interventionist model}

Gauthier (1996, p. 204) identifies the non-interventionist model as one in which government intervention is restricted to dealing with the most vulnerable families. While a non-interventionist government may take a positive view of the institutions of marriage and the family, this does not justify the government intervening to promote them. Rather, a noninterventionist government takes the position that the best way to support these institutions is to allow them to develop on their own.

From these ideological perspectives, I suggest that the following table (based primarily on policies present in the three countries at hand) represents the policies that an ideal-typical adherent of each perspective would promote.

Table: Characteristics of relationships policy models

\begin{tabular}{|c|c|c|c|}
\hline & Pro-traditionalism & Pro-egalitarianism & Non-interventionism \\
\hline \multirow[t]{3}{*}{$\begin{array}{l}\text { Legal status of } \\
\text { relationships }\end{array}$} & $\begin{array}{l}\text { High level of rights and } \\
\text { responsibilities for } \\
\text { married couples in } \\
\text { comparison to } \\
\text { cohabitants }\end{array}$ & $\begin{array}{l}\text { Alternative relationship } \\
\text { institutions developed } \\
\text { alongside or in place of } \\
\text { marriage }\end{array}$ & $\begin{array}{l}\text { Provision of legal } \\
\text { frameworks for } \\
\text { alternative family forms } \\
\text { as needs or injustice arise }\end{array}$ \\
\hline & \multirow[t]{2}{*}{$\begin{array}{l}\text { Gendered rights and } \\
\text { responsibilities within } \\
\text { marriage }\end{array}$} & $\begin{array}{l}\text { Degendered rights and } \\
\text { responsibilities within } \\
\text { marriage }\end{array}$ & $\begin{array}{l}\text { Degendered rights and } \\
\text { responsibilities within } \\
\text { marriage }\end{array}$ \\
\hline & & $\begin{array}{l}\text { Alternative family forms } \\
\text { possess equal rights and } \\
\text { responsibilities }\end{array}$ & $\begin{array}{l}\text { Substantial equality of } \\
\text { rights and } \\
\text { responsibilities, but } \\
\text { retention of exclusive } \\
\text { categories }\end{array}$ \\
\hline $\begin{array}{l}\text { Same-sex } \\
\text { relationships }\end{array}$ & No recognition & Equal recognition & $\begin{array}{l}\text { Marriage exclusively } \\
\text { heterosexual, same-sex } \\
\text { rights dealt with through } \\
\text { alternative categories }\end{array}$ \\
\hline \multirow{3}{*}{$\begin{array}{l}\text { Relationship } \\
\text { education }\end{array}$} & Marriage education & Relationship education & \multirow[t]{3}{*}{ Anti-violence education } \\
\hline & $\begin{array}{l}\text { Promotion of marriage } \\
\text { as ideal family form }\end{array}$ & \multirow[t]{2}{*}{$\begin{array}{l}\text { Promotion of equality } \\
\text { within relationships }\end{array}$} & \\
\hline & $\begin{array}{l}\text { Subsidised or } \\
\text { compulsory premarital } \\
\text { counselling }\end{array}$ & & \\
\hline
\end{tabular}




\begin{tabular}{|l|l|l|l|}
\hline $\begin{array}{l}\text { Family } \\
\text { breakdown }\end{array}$ & $\begin{array}{l}\text { Non-exclusive no fault } \\
\text { divorce }\end{array}$ & $\begin{array}{l}\text { Exclusive no-fault } \\
\text { divorce }\end{array}$ & $\begin{array}{l}\text { Exclusive no-fault } \\
\text { divorce }\end{array}$ \\
\cline { 2 - 4 } & $\begin{array}{l}\text { Fault-based property } \\
\text { settlements }\end{array}$ & $\begin{array}{l}\text { Equality of outcomes in } \\
\text { property settlements }\end{array}$ & $\begin{array}{l}\text { Equality of division in } \\
\text { property settlements }\end{array}$ \\
\cline { 2 - 4 } & $\begin{array}{l}\text { Subsidised or } \\
\text { compulsory } \\
\text { reconciliatory } \\
\text { counselling }\end{array}$ & $\begin{array}{l}\text { Subsidised or } \\
\text { compulsory conciliation, } \\
\text { potentially also } \\
\text { reconciliatory } \\
\text { counselling }\end{array}$ & $\begin{array}{l}\text { Limited support for } \\
\text { conciliation }\end{array}$ \\
\cline { 2 - 4 } & $\begin{array}{l}\text { Only marriages } \\
\text { protected }\end{array}$ & $\begin{array}{l}\text { All relationships } \\
\text { protected equally }\end{array}$ & $\begin{array}{l}\text { All relationships } \\
\text { protected, not necessarily } \\
\text { equally }\end{array}$ \\
\hline $\begin{array}{l}\text { Tax and } \\
\text { welfare }\end{array}$ & $\begin{array}{l}\text { Tax advantages for } \\
\text { male-breadwinner } \\
\text { marriages }\end{array}$ & $\begin{array}{l}\text { Individual basis for } \\
\text { taxation }\end{array}$ & $\begin{array}{l}\text { Individual basis for } \\
\text { taxation }\end{array}$ \\
\cline { 2 - 4 } & $\begin{array}{l}\text { Preferential treatment of } \\
\text { widows over other sole } \\
\text { parents }\end{array}$ & $\begin{array}{l}\text { Individual basis for } \\
\text { welfare entitlements }\end{array}$ & $\begin{array}{l}\text { Married people treated } \\
\text { differently to reduce costs }\end{array}$ \\
\hline
\end{tabular}

\section{DIVERGING MODELS}

On the basis of this scheme, none of the three countries has employed a "pure" model at any point between 1990 and 2014. In 1990, each country mixed elements of the protraditionalist and non-interventionist models. Since this point, however, while few aspects of American policy have changed markedly, Australasian policy has almost entirely rejected pro-traditionalism for non-interventionism (though New Zealand policy also includes proegalitarian elements).

\section{Individual policy areas}

Divorce law is one of the most stable areas of relationships policy in all three countries. While the ancillary practices surrounding relationship breakdowns have shifted somewhat, the bases for divorce remain static. Two basic models of divorce exist: the exclusive no-fault model practised across Australasia and the Western United States, and the non-exclusive no-fault model practised across the North-eastern and Southern United States.

The two models are fundamentally non-interventionist, rejecting state intervention to force dysfunctional couples to stay together or to prevent them from forming new 
relationships. However, while the exclusive model rejects state inspection of the details of a marriage, the non-exclusive model upholds a "correct" form of marital behaviour, condemning sexual unfaithfulness and intemperance. While this sometimes gives wives leverage over their husbands (especially where fault extends into property settlements), the primary purpose of fault grounds is the enforcement of traditional morality. Pre-divorce waiting periods in Australasia perform a similar role, allowing the state to uphold the permanence of marriage, but do not allow the state to police behaviour within relationships. Marriages are considered social goods worth preserving, but remain fundamentally private. Offering covenant marriage does not significantly change the character of a divorce model because, while theoretically pro-traditionalist, covenant marriages retain no-fault divorce and are optional in any case.

In 1990, Australasian family courts and some American states provided access to marriage counselling services. Although relationship reconciliation counselling is not necessary pro-traditionalist, these services privileged marital relationships, treated marriage as central to family wellbeing, and allowed courts to compel couples to attempt reconciliation. Other American states lacked a tradition of state-provided relationship services; while law sometimes required that courts consider reconciliation, the government provided no meaningful assistance to facilitate it. Over the ensuring twenty-five years, the Australasian systems and many of the American states with conciliation courts that had provided reconciliation support transitioned to a non-interventionist approach emphasising conciliation and child wellbeing (Association of Family and Conciliation Courts, 2014). The recognition of de facto relationships in New Zealand meant that it first moved to a quasiegalitarian system that treated all relationships as potentially worth preserving. The termination of these services, however, means that there is now a broad non-interventionist consensus across the three countries in this area.

The first prominent point of difference between Australasian and American relationships policy development is the issue of alternative heterosexual relationships. By 1990, Australian states had already begun devising formal legal regimes to deal with the aftermath of de facto relationships, a non-interventionist approach that retained the privileged position of marriage while providing security for a vulnerable group. New Zealand followed suit in 2001 in a slightly more egalitarian vein, placing de facto property in the same scheme as matrimonial property rather than in a separate, potential inferior process, as the Australian constitution necessitated. Further egalitarian shifts followed in each country; New Zealand 
and the Australian Commonwealth dramatically reduced the differences between the rights and responsibilities of de facto and married couples in 2004 and 2008 respectively. New Zealand's 2004 establishment of civil unions as an alternative institution highlighted its proegalitarian shift; marriage-sceptics could affirm their commitment without buying into the cultural assumptions around marriage. While registered relationships (from 2003) in some Australian states perform a similar role, these are largely not ceremonial in nature.

American policies for alternative heterosexual relationships remain almost exclusively pro-traditionalist. Most unions devised after 1996 to stave off judicial demands for same-sex marriage apply only to same-sex couples and elderly opposite-sex couples (allowing them to retain social security claims based on previous marriages (Bowman, 2004, p. 137). Washington's "marriage-like" relationship category equates to the non-interventionist de facto property reforms in Australasia, but in most cases cohabitants are treated as family only in extreme circumstances such as following work-related deaths (Bowman, 2004; Francis, 2014, p. 140). Outside Washington, these policies are all clearly pro-traditionalist, providing clear incentives for couples to marry and disadvantaging financially-vulnerable people who feel too insecure to marry and those ideologically opposed to marriage.

The swiftest changes in policy have occurred in the treatment of same-sex relationships. Before 1994, no country or state provided meaningful recognition for same-sex relationships. The federal governments of America and Australia accentuated this protraditionalist stance in 1996 and 2004 respectively by defining marriage in heterosexual terms. However, New Zealand and the Australian states pursued a non-interventionist path, retaining the exclusivity of marriage while extending rights to same-sex couples on the same basis as alternative heterosexual couples, effectively granting these relationships "accepted, but not preferred" status. New Zealand and Australia subsequently granted alternative heterosexual couples equivalent rights and responsibilities to marriage. New Zealand then adopted same-sex marriage, and American courts began to enforce same-sex marriage recognition, a pro-egalitarian turn, though not necessarily a decisive one.

The fate of transitional alternative relationships following the recognition of same-sex marriage is a revealing point of divergence. Whereas New Zealand retains both civil unions and same-sex marriage, American states that create civil unions or partnerships and subsequently legalise same-sex marriage typically terminate the registration of new civil unions (Vermont Freedom to Marry, n.d.) or convert existing partnerships into marriages (Washington Secretary of State, 2014). Similarly, the ACT Marriage Equality (Same Sex) 
Act 2013 would have repealed that state's Civil Unions Act 2012 had it survived judicial review. Once same-sex couples are eligible to marry, they become subject to the same protraditionalist preference for marriage as opposite-sex couples. Civil unions exist as a genuine alternative relationship only in New Zealand.

The use of different tax regimes for married and single earners in America is a fundamental point of difference between its relationships policies and those of Australia and New Zealand. The married tax regime is strongly pro-traditionalist both because it exclusively benefits married couples (and, before 2013, only heterosexual married couples) rather than all financially interdependent couples, and because it advantages sole-earner families, most likely to be male-breadwinner families. The Republican marriage penalty reform package emphasised these characteristics, minimising financial disincentives against marriage for dual-earner couples while preserving the single-earner advantage.

While neither Australia nor New Zealand has joint taxation - so the basic tax regime in each is non-interventionist - Australia's adoption of FTB-B was a somewhat protraditionalist move as it advantaged single-earner families. Eligibility and payment levels for benefits in both countries take relationship status into account (DHS, 2014b), but as a means of reducing government obligations, rather than to promote relationship formation. Both governments took a functionalist approach here even while their relationships policy otherwise relied exclusively on form; Australia's Social Security Act 1991 (s. 4(2-3)) based eligibility around a definition of a couple that included couples in "marriage-like relationship[s]", while New Zealand's Social Security Act 1964 (s. 63) treats spouses living apart as unpartnered, and unmarried couples as partnered.

America and Australia have increased government support for premarital education. In America, this is constructed in a strongly pro-traditionalist fashion; state-based initiatives are connected to licensing processes, so while people in other relationships might access them, they would not receive the incentives in place to encourage couples to make use of them. HMRF is not confined exclusively to premarital education; HMRF-funded programmes may attempt to shape American marriages at many different stages. USC 42§603(a)(2)(C)(i) allows faith-based organisations to claim HMRF funding, potentially allowing them to promote traditionalist interpretations of marriage, although there is no requirement for this to happen. While people in other relationships may access some HMRF-funded services, the programme promotes marriage as a mechanism for improving their relationships. 
Kevin Andrews suggests that his premarital counselling scheme continues a longer history of the Australian federal government funding organisations that provide relationship education (Penberth \& Andrews, 2014). Andrews' scheme nonetheless reflects a new emphasis on the area. While Andrews' intent is explicit in addressing the rate and cost of divorce, the pro-traditional intent of the scheme is suppressed by its non-interventionist construction (Maley \& Bright, 2013).

\section{Overall changes}

While there was some variation in policy specifics between the three countries in the 1990s, they nevertheless shared a common set of values and assumptions at their core. Each privileged marriage over other relationships and denied recognition to same-sex relationships, but allowed dysfunctional couples to divorce and remarry freely. American policy placed somewhat more emphasis on shaping behaviour within relationships, while Australia and New Zealand provided greater support for couples to reconcile.

Australia and America made pro-traditionalist changes from 1996, increasing financial incentives for "traditional" families and re-emphasising the heterosexual exclusivity of marriage. However, the federal pro-traditionalist turn in Australia was mitigated by statelevel developments protecting alternative heterosexual and homosexual relationships, and the erosion of support for reconciliation in the Family Court. With support for male-breadwinner families on the way out, Australia must be understood as a non-interventionist regime. New Zealand did not make the same pro-traditionalist turn, but echoed the other Australian developments, moving to a more firmly non-interventionist model with some pro-egalitarian aspects, reinforced by its adoption of same-sex marriage and retention of civil unions.

While court judgements supporting same-sex marriage in the United States have eroded one pro-traditionalist aspect of its policy, they have also reinforced the position of marriage at the centre of American relationships policy. Marriage may now be a broader institution, but it is once again the only institution, supported and used by an array of federal and state policies. Consequently, American relationships policy remains a hybrid of protraditionalism and non-interventionism. 


\section{CHAPTER 8: ANALYSIS}

\section{PATH DEPENDENCY}

In this section, I discuss the existence of path dependent processes in relationships policy, examining how early decisions constrain policy choices in certain areas. Path dependence is a core concept of historical institutionalism; supportive theorists argue that decisions made early in the history of institutions will "persistent[ly] influence" that institution. Consequently, Peters (2008, pp. 3-4) suggests that path dependence can explain policy persistence, but that this focus prevents it from developing strong explanations for policy change. Strach (2007, pp. 12-13) suggests that policies consist of sets of values and assumptions, and that these may be either core or peripheral elements of policies. "Policy entrepreneurs" may exploit "policy gaps" that form as the values and assumptions of society diverge from those found in policies. Core values and assumptions are far less vulnerable to change than peripheral issues, because resolving gaps in the core of a policy involves a complete restructuring.

Pierson (2000) observes that "path dependence" means little when used to simply state the importance of observing policy trajectories through history. Pierson suggests that an "increasing returns" model of path dependence is most useful. In this model, each decision along a particular path makes it more likely for subsequent decisions to follow the same path rather than switching, because the relative cost of switching paths rises with each step along the initial path. Although this language is tied to economics it may equally well involve social or political costs as changes to well-established practices disrupt society and well-established policy-based rights become perceived as inherent.

Mahoney (2000, p. 511) suggests that path dependent processes possess three properties. They must be "contingent": if an initial decision is predictable from its circumstances, then a sequence of events reacting to that event may be a response to those initial circumstances, rather than the policy choice itself. Additionally, path dependent processes must be most sensitive to events occurring early in their history, and should have some form of "inertia". In an "increasing returns" process, inertia comes from policies that are "self-reinforcing". "Reactive" sequences may also occur in which inertia results from logical processes of reactions and counter-reactions. 


\section{Financial matters}

America's 2001 pro-marriage tax changes are the product of a path with its origins in American federalism. The adoption of marital taxation was not in itself necessarily a contingent event. Strach (2007, p. 96) suggests that it stemmed from community property states treating married couples as single entities. This practice originated in the Spanish origins of most community states' legal systems (Leiter, 2008, p. 459), setting the contingent event for the path further back in history. The federal government could not readily change these practices; joint taxation allowed it to treat married couples nationwide equitably. The Australasian governments might have devised joint taxation systems without this restriction but did not; Australia's Income Tax Assessment Act 1913 and New Zealand's Land and Income Assessment Act 1891 treated income on a purely individual basis; the latter Act explicitly stated that a married woman should be treated "as if she were sole and unmarried" (s. 39).

Australasian politicians' attempts to create income-splitting systems suggest that there are high costs to changing embedded tax systems. John Howard's Family Tax Initiative and Peter Dunne's Taxation (Income-sharing Tax Credit) Bill 2010 in New Zealand targeted partnered parents (rather than marriages or even couples in general). While the Family Tax Initiative went into force and survived a considerably less pro-traditionalist ALP government, it was a marginal expenditure (initially a minor tax bracket adjustment, then a means-tested payment), rather than a significant restructuring of the income tax system, leaving it vulnerable to Abbott's austerity drive. Dunne's bill, a more significant restructuring of tax calculations, failed to attract support beyond its first reading. Howard retained the core assumption of individual taxation by altering its peripheral assumptions (that it should acknowledge single-earner families); Dunne sought to change core assumptions without a sufficient policy gap to justify this restructuring. The Christian Democrats (1996) did identify a need to prevent married couples from financial disadvantage relative to cohabitants in the 1990s, but without demonstrating a disadvantage comparable to that faced by some Americans. Moreover, neither major New Zealand party took this up as a core issue, as in America, where both major presidential candidates promised marriage penalty relief in 2000 (Bush-Cheney, 2000; Gore-Lieberman, 2000), and the Christian Democrats did not enter Parliament to bargain for reform.

The use of functional bases for determining welfare entitlements in Australasia also contributed to reducing marriage penalties in these systems. This undermined the case for 
favouring marriage in other areas, facilitating the development of de facto relationship protections. Recognising cohabitation "in the nature of marriage" allowed governments to remove financial incentives for couples to cohabit without marrying (a pro-traditionalist justification) and reduced unnecessary expenditure (a non-interventionist justification). It also created a moral precedent for recognising de facto relationships by establishing the government's right to scrutinise its citizens' "private" lives, and a legal precedent for defining these relationships (Sackville, Gressier, \& Cass, 1981); America lacks both precedents. Furthermore, it created perceptions of injustice by assuming that de facto partners would take responsibility for each other without granting them corresponding rights.

\section{Ending relationships}

Relationship exit policy is an obvious area to look for path dependence as its basic architecture (divorce law) has remained almost unchanged since the 1980s. While Pierson and Mahoney prefer to look for 'small moments' leading to large developments, and the adoption of no-fault divorce is a 'big moment' in the context of relationships policy, the field nevertheless meets Mahoney's criteria for path dependence.

Whether the adoption of no-fault divorce constitutes a contingent event is not the crucial question. The conditions of no-fault divorce's establishment - post-war acceleration in marital breakdown - do explain why divorce policy was of interest to all (if not necessarily why they settled on no-fault divorce), but they do not explain why various states and countries selected particular approaches to no-fault divorce. Geographical groupings exist that suggest policy transfer between neighbours, and Wolfinger (2005, p. 407) describes California's 1970 law as the "landmark no-fault divorce law", but not all states followed their neighbours' approaches, nor did states that followed California necessarily follow its example. The Uniform Law Commission disseminated a (exclusive no-fault) Marriage and Divorce Act in 1973, but only six states adopted it ${ }^{18}$ (Sweet, 2005; Uniform Law Commission, 2014). Most importantly, these factors do not explain why one policy would be inherently more suitable to the circumstances of a particular country or state than another, so these original policies can be considered contingent events.

The persistence of the divorce laws of the 1970s and 1980s throughout 1990-2014 indicates in itself that early events strongly impact later policy developments. When changes occur, they reinforce the character of these original developments, rather than changing

\footnotetext{
${ }^{18}$ Supposedly including Georgia, which retains fault grounds (Official Code of Georgia §19-5-3).
} 
overall models. New York, the state with the most traditionalist divorce regime, pegged a unilateral ground to its existing law; New Jersey's Act No. 6 of 2007 added a somewhat shorter separation-based ground to its existing law. This liberalisation by addition recalls the process of adding divorce grounds prior to the no-fault "revolution". Even covenant marriage, which emerged from religious conservatives' alarm about the future of the institution of marriage triggered by Baehr v. Lewin (Nock et al., 1999, pp. 45-46), retained the very structures that it rebelled against. New Zealand and Australian law is similarly static; while John Howard promoted a longer separation period in 1975 (Murray, 2010, p. 243), his government made no attempts to fulfil this. Helen Clark's 1999-2008 New Zealand government retained the FPA's 2-year separation period despite its purported antagonism toward marriage.

De facto relationships policy may contribute to static divorce laws. When people can leave marriages and enter second relationships without officially divorcing their spouses, the importance of a speedy divorce process is considerably reduced. Consequently, Australia and New Zealand's provision for de facto polygamy may relieve pressure on these countries' separation periods, while America's short or non-existent waiting periods eliminate one justification for recognising de facto relationships. The key issue in Australia and New Zealand is not an efficient divorce, but an efficient separation.

\section{Same-sex marriage}

The progress of same-sex marriage through the American legal system appears on one level to display a pattern of reactive path dependence. The reactions and counter-reactions to court actions beginning with Baehr v. Lewin follow a logical pattern as guided by American constitutional processes. The possibility for a Hawai ian court to force the rest of America to recognise same-sex marriages created an environment in which the logical reaction for samesex marriage opponents was to disable this mechanism through DOMA and pursue laws allowing their state to ignore others' decisions on the grounds of public policy. These demonstrations of the legislative strength of same-sex marriage opponents forced LGBT rights campaigners to pursue judicial review of these laws. Their victory in Massachusetts revealed the vulnerability of unentrenched legislation, forcing same-sex marriage opponents to target state constitutions, leading in turn to challenges to state constitutions on the basis of the US constitution. 
While the decisions of the interest groups involved in this process are logically consequent to the decisions made in previous steps, this does not necessarily apply to judges' decisions. Constitutional law is a highly contested area, and judges' opinions may be heavily guided by factors that lie outside the strict contents of laws and constitutions, such as public opinion (Kagan, 2004) and personal ideology. However, because the actions of one state potentially affect many others, only one decision favourable to LGBT rights advocates is necessary to advance the chain of events. Increasing returns may also come into play as the path continues.

Increasing public acceptance of same-sex relationships may affect judges' decisionmaking, but this may itself be related to the decisions of other judges to recognise same-sex relationships. The recognition of same-sex relationships in one state creates knowledge (whether 'academic' or 'lay') about its social effects, potentially influencing proceedings in other jurisdictions. Increasing returns are also significant in that, as the reactive sequence proceeds, the costs of action for same-sex marriage opponents increase dramatically. Persuading legislators to clarify existing, popular policy is relatively simple, and raising support for a state constitutional amendment is somewhat more complex, but pursuing an amendment to the US Constitution requires a vast organisational capacity, given that it requires the consent of supermajorities of the States and, usually, of both houses of Congress (Bianco \& Canon, 2011, p. 56). In 2006, when a constitutional amendment might conceivably have succeeded, its opponents could still claim that federal intervention was unnecessary as states were deciding the issue themselves (Baldwin, 2006, p. H5293). By the time that LGBT activists won a federal constitutional case, both public opinion and control of the Senate had shifted.

\section{INTEREST REPRESENTATION}

While path dependence is an important concept in understanding why particular policy options are very difficult to achieve, alternative explanations are needed for understanding why many policy changes occur. The analysis of institutions of interest representation helps to identify not only how one policy option might be selected from a range of possible solutions, but also why the policy problem at hand is being addressed. In this section, I explore how the policy-making influence exercised by a range of interests (religious, women's, LGBT, and legal) is affected by the institutional contexts of the three countries. 


\section{5}

\section{Religious interests}

Conservative Christians (or the "Christian Right") are significant supporters of protraditionalist relationships policies. The Christian Right has mobilised in recent decades as a series of social movements (and counter-movements), interest groups, think-tanks, parties and candidates. While the Christian Right is most closely associated with conservative Protestantism, Protestants have made alliances with conservative Catholics on some issues (Lugg, 2007, pp. 324-325).

The American Christian Right is a complex, multi-layered network; prominent national-level organisations such as the Christian Coalition and Focus on the Family work alongside local organisations and grassroots members (Myers, 2010, pp. 273-274). Politicised Australian organisations such as the Australian Christian Lobby (ACL) adopt centrist images (Melleuish, 2010, pp. 916-917), although the ACL nevertheless takes protraditionalist positions on family-related issues (ACL, 2014a, 2014b). Key Anglican and Catholic leaders also campaign on these issues (Melleuish, 2010, pp. 918-920), alongside several microparties associated with Pentecostal churches. New Zealand lacks prominent, explicitly-Christian, national-level conservative interest groups, although the theoretically secular Family First NZ organisation has campaigned on Christian conservative issues since 2006 (Family First NZ, 2006).

The American Christian Right has been most successful in shaping relationships policy. Americans are considerably more likely than their Antipodean counterparts to believe strongly and attend church regularly (Lipka, 2013), creating greater incentives for politicians to appeal to religious views. The American political system also offers structural opportunities for religious groups. The importance of local organisations, particularly in candidate selection, means that local religious interests may capture local selection processes to promote sympathetic candidates. Bruce (2003, p. 422) suggests that the large number of elections in America benefits religious interests because voters organised through religious organisations may be more highly motivated to fully participate than the population as a whole. Religious organisations' guidance may be most influential in low profile races such as state legislative contests, which are significant for relationships policy because of states' lead role in the area. American legislators' relative independence also benefits conservative Christian interests by offering legislators from conservative areas license to represent their constituents without conforming to the expectations of centrally organised parties trying to capture that centre. Although American legislators do not necessarily represent the most 
conservative churches, they are certainly more likely to be Christian than the population as a whole (Miller, 2013).

The selection processes employed by the major parties of New Zealand and Australia make similar grassroots attempts to capture selection processes impractical. Australian Senate pre-selections and New Zealand list selection processes take place at the state and national levels respectively, so are not subject to branch-packing. New Zealand local branches do not have a free selection of candidates; the NZNP hierarchy may block undesirable candidates (NZNP, 2013, sec. 94), while Labour selection committees include national representatives (NZLP, 2014, sec. 314). Australian state parties possess varying but significant roles in House pre-selections, and may replace locally-chosen candidates (Crook, 2009a, 2009b); the Western Australian Liberals supply delegates to selection committees and can unilaterally cancel selections (LPA, 2012, sec. 117(1)(b); 130). While Christian groups have recently been accused of branch-packing to dictate selections in both countries, they failed to influence the outcomes (Cheng, 2014; Kerr, 2011).

The LPA, NPA, and ALP have significant Christian connections which occasionally influence their decision-making, although they are not necessarily connected to the Christian Right as a movement. The NPA Constitution sets the promotion of "a society based on Christian ethics and loyalty to the Crown" as its first objective (NPA, 2013, s. 2.1(a)(i)). The ALP and LPA historically enjoyed the support of Catholics and Protestants respectively, but this has weakened recently; weakening interdenominational antagonism has seen more Catholics joining and exercising authority inside the LPA, while the ALP has become the party of secularism (Brett, 2003, pp. 35, 132) - though Catholics certainly retain influence within some factions. Warhurst (2006) suggests that Catholics' rising influence within the LPA caused socially-conservative policy changes during the Howard government. Kevin Andrews and Tony Abbott featured prominently in this rise; Andrews and Abbott enjoy still greater potential influence in the current government as Prime Minister and (until December 2014) Minister for Social Services respectively.

The relatively open party systems of Australia and post-MMP New Zealand allow conservative Christians to bypass major parties by forming movement parties. This theoretically allows Christian politicians to prioritise moral issues that might be lost amidst competing concerns in major parties. These parties' electoral performances, however, suggest that this is a false opportunity, and may actually hurt New Zealand Christian conservatives. New Zealand Christian parties' support is neither sufficiently localised to meet the electorate 
seat threshold, nor sufficiently broad-based to meet the party vote threshold. To enter Parliament, Christians have had to moderate their demands in keeping with Ezrow's (2011) proposition that parties in proportional systems construct policies for median voters rather than their base. Candidates from Future New Zealand (itself the moderate counterpart of the Christian Heritage Party (Edwards, 2003, p. 180)) entered Parliament in 2002 and 2005 only by allying with the liberal United New Zealand party.

Although confidence and supply agreements with Labour contributed to the development of the Families Commission (Clark \& Dunne, 2002, 2005), the Commission never matched the vision embodied in these agreements, and the agreements themselves avoided promoting pro-traditionalist views of family. Moderating their demands allowed socially-conservative Christian politicians to enter parliament and argue against key policy such as the RSRB and CUA, but did not allow them to promote pro-traditionalist policies. Despite MMP's apparent openness, the choice for conservative Christians is between compromised representation within broader parties or no representation (and 'wasted' votes) on their own. The case of John Stringer demonstrates the capacity for movement parties to erode the Christian Right's position within the NZNP; Stringer was involved in promoting conservative Christian ideas and candidates through National's "Christian Voice" group in 1999, but later moved to the Conservative Party (Edwards, 2003, p. 345; Young, 2014).

Australian Christian conservatives have been marginally more successful in gaining Parliamentary representation as movement parties. The Christian Democratic Party has a small contingent in New South Wales, but has only been represented at federal level by a Liberal defector. Family First has gained representation in the Senate and some state legislatures. Family First does not explicitly market itself as Christian, but draws candidates and support from Pentecostal churches (Fitzgerald, 2014; Murphy, 2004). Even when unsuccessful, however, these parties may exercise a certain degree of influence through preference deals with larger parties.

Consequently, during the MMP era, the balance between moral conservatives and liberals with the NZNP has been weighted heavily towards liberals, while the Australian Coalition and the Republicans have given greater power to Christian conservatives. This position allows conservatives to periodically override economic rationalist and social liberals' objections. Republic Chuck Grassley (2005, pp. S13095, S13125) pointed to the social and economic benefits to be obtained from promoting marriage to the poor, while Kevin Andrews (2014) justified relationship education spending on the costs of family breakdown. In each 
case, conservative politicians successfully pushed pro-traditionalist expenditure within tight fiscal environments, although the phase-out of FTB-B at the same time as Andrews' scheme suggests that these pro-traditionalist expenditures remain vulnerable to economic pressures even with considerable moral conservative representation.

\section{Women's interests}

As Christian conservatives have campaigned for pro-traditionalist reforms, the feminist movement has been a voice for pro-egalitarian reform. Feminists have long criticised marriage as an oppressive institution, demanding its reform or, on the radical flank, eradication (Auchmuty, 2012, p. 82). "Traditional" marriage, in feminist critiques, constrains women's life choices, making them financially dependent on men. Consequently, divorce and property law reform and support for alternative relationships are feminist issues, although they must compete with a large array of other issues for the attention of the movement.

Feminists have not formed movement parties to contest elections independently ${ }^{19}$; rather, feminists work within the institutional structures of mainstream parties, or outside them to lobby policy-makers. American feminist organisations such as EMILY's List (a partisan Democratic organisation) and the National Women's Political Caucus (NWPC) take an active role in elections by endorsing and co-ordinating fundraising for feminist women (EMILY's List, 2014; NWPC, 2014a). Both organisations, however, focus primarily on abortion, rather than relationships policy. EMILY's List (Australia) (2014) performs a similar role for the ALP, and does look beyond abortion.

The radicalism of feminist organisations varies considerably, and indeed many women's organisations are either anti-feminist or not explicitly feminist. CWfA (2014), which claims to be America's "largest public policy women's organization", marries women's interests with Christian conservatism; this allows conservatives to challenge feminists' organisations claims to represent all women, and to frame the pro-traditionalist agenda as positive for women rather than oppressive. In New Zealand and Australia, national networks of women's organisations encompass both feminist and non-feminist organisations, occasionally complicating their policy commentary or preventing them from commenting firmly on controversial issues. On income splitting, for example, the National Council of Women of New Zealand (NCWNZ, 2009) presented both strongly-favourable and strongly-

\footnotetext{
${ }^{19}$ Except for Australia's short-lived What Women Want party.
} 
opposed perspectives. While NCWNZ did participate in debate on the PRA (Yates (2001)), along with other women's organisations, it did not initiate the debate.

Hart (2003, p. 397) suggests that women's representation in legislatures is important because male-dominated legislatures neglect issues that are chiefly of importance to women. Women's representation help to raise women's problems to public attention, and then shape the policies developed to address them. Women legislators must, however, still work through standard legislative procedures to bring their issues to attention. Most Australasian legislation is initiated by government, rather than backbenchers (New Zealand Parliament, 2009; Parliament of Australia, 2014a, p. 3), requiring women to be represented in government, rather than simply in legislatures, to significantly influence policy.

The Congressional Caucus for Women's Issues unites women legislators from both major American parties to promote action of women's issues (Keremidchieva, 2012, pp. 1819) and lobby political and administrative leaders (Ernst, 2006, pp. 223-227). However, the ideological differences within this caucus make it an impractical venue for feminists to use to promote pro-egalitarian policy. Consequently, the Caucus' focus is on protections for vulnerable women (particularly relating to healthcare (Daly, 2009; Women's Policy, 2014)), rather than transforming oppressive structures.

Engaging with mainstream political parties can be an uncertain mechanism for women to advance their interests. While almost all major parties in each country have processes to include women in their internal politics, these do not necessarily result in the election of women. The major parties of the US and Australia require significant representation of women in their national organisations, but only the ALP sets a target for candidates (ALP, 2011, pt. B(10); DNC, 2012; LPA, 2010, pt. X; NPA, 2013, sec. 8.1; RNC, 2014). The NZLP (2014, s. 351) uses affirmative action throughout its structure, including in list selection, but National (2013) makes no provisions for gender-based representation. The interactions of internal rules with electoral systems produce starkly differing results. The NZNP elects a greater proportion of women than its right-wing colleagues, while the ALP elects a greater proportion of women than its left-wing colleagues (NWPC, 2014b; NZEC, 2011; Parliament of Australia, 2014b). The ALP's quota for women's representation not only ensures the presence of women in Parliament, but also frees up interest group resources for other priorities. EMILY's List in Australia can focus its attention on developing endorsed candidates, whereas the American group must start with candidate recruitment (EMILY's List, 2014; EMILY's List (Australia), 2014). 
The ascent of women to the leadership of both major New Zealand parties in the 1990s may have contributed to the elevation of de facto property legislation from a vague commitment in Labour manifestos (NZLP, 1987, p. 26) (which the party did not action in government) to a national policy issue, and to the eventual shape of the legislation. National (1993, 1996) did not promote relationship property reform as a significant issue, producing a bill only after Jenny Shipley - who had been working on the issue for some time (Shipley, 1998, p. 6699) - became Prime Minister. Shipley suggested that Helen Clark had been unable to persuade her colleagues to take up the issue; ascending to the Prime Ministership allowed these women leaders to set the agenda to advance women's interests for the first time. Upon the election of the Clark government, the new attorney-general Margaret Wilson (a member of a number of gender equality groups) reshaped the bill. While the select committee prevented Wilson's attempts to remove marriage language from the bill, the new bill was considerably more pro-egalitarian than National's proposal.

\section{LGBT interests}

LGBT interests are somewhat less institutionalised and more social movement-based than women's interests. While LGBT representation in legislatures has increased and LGBT networks have become features of left-wing parties, the marriage equality movement has developed alongside or outside these formal political institutions. In Australasia this involves a mixture of dedicated issue organisations and networks, broader LGBT rights organisations and networks and party networks, while in America it also involves dedicated legal advocacy organisations.

LGBT Labo(u)r party members have developed "Rainbow" networks. Openly-gay MP Tim Barnett and former (and future) MP Chris Carter established New Zealand Rainbow Labour (NZRL) in 1997 to encourage LGBT political involvement (NZRL, 2000), while Rainbow Labor networks in Australia were formed from 2002 (Rainbow Labor QLD, 2014). The Democrats also include various LGBT networks, including the congressional LGBT Equality Caucus (2014) (which includes straight legislators), founded in 2008, the National Stonewall Democrats campaigning organisation between 1998 and 2013 (Lavers, 2013), and various state-level organisations (eg. Arizona LGBT Caucus, 2013).

These organisations claim significant roles in policy-making, including lobbying for civil unions in New Zealand (NZRL, 2007) and persuading the ALP to formally support 
same-sex marriage (Karvelas, 2013). While this is an important role, strong (but not universal) support within left-wing parties is often insufficient in advancing pro-LGBT policies. While NZLP representatives supported civil unions nearly unanimously, the narrow electoral margins of MMP forced them to rely on right-wing social liberals, whose support became even more crucial in passing same-sex marriage from opposition. In Australia, winning the formal backing of the ALP for same-sex marriage has proven insufficient, because of both strong conservative factions within the party and Tony Abbott's refusal to allow a conscience vote, disabling access to social liberal Liberals.

American LGBT lobbyists adapt their tactics to exploit the opportunities provided by the courts. Not all same-sex marriage cases have had strong organisational support. Nevertheless, one organisation - Gay \& Lesbian Advocates \& Defenders (GLAD) - provided representation for several of the most significant cases, winning civil unions in Vermont, same-sex marriage in Massachusetts (GLAD, 2008), and a finding that Section 3 of DOMA was unconstitutional (GLAD, 2013). The involvement of a national movement organisation in these cases enabled plaintiffs to sustain complex, multi-year legal challenges, while developing the capacity of the organisation itself.

The practical impact of non-legal movement organisations is more difficult to gauge. Each country has both generalist LGBT rights organisations that build awareness of and support for sexual minorities, and specialist same-sex marriage lobbying organisations. American organisations may influence public support with reasonably direct consequences for policy by participating in referenda (Human Rights Campaign, 2014); in most cases this means resisting pro-traditionalist initiatives rather than advancing pro-egalitarian policy. Promoting same-sex relationship rights via referendum would have been technically possible in New Zealand, but would also have been extraordinarily organisationally-demanding without guaranteeing government action.

Influencing public opinion influences policy indirectly by changing the forces affecting politicians' decision-making. Changing public opinion about same-sex marriage creates a policy gap between the assumptions of what marriage looks like held by existing policy and by the public. This creates opportunities for LGBT-friendly politicians to seize, while putting electoral pressure on ambivalent or opposed politicians. Generalist organisations facilitate this by promoting its agenda to media organisations and the wider community, and encouraging political participation by the LGBT community (Gay \& Lesbian 
Rights Lobby, 2009; GLAAD, 2014). Issue organisations produce issue-specific educational resources, facilitate citizen involvement in political processes, and co-ordinate networks of supportive organisations (Australian Marriage Equality, 2014a; Freedom to Marry, 2014; Marriage Equality, 2013).

There are interesting contrasts in how issue-specific organisations adapt to the institutional opportunities available to them. While Freedom to Marry participates in court actions in addition to building public support, Australasian campaigns focus on political lobbying. These lobbying campaigns are themselves very different. While Australian Marriage Equality is a unitary organisation, its New Zealand counterpart was a coalition of partners. Consequently, whereas the Australian campaign is confronting its major institutional challenge (Abbott's whip on same-sex marriage) by co-ordinating citizen emails (Australian Marriage Equality, 2014b), the New Zealand campaign seized the opportunities created by party structures by partnering with the youth wings of five parties (including ACT and National) (Marriage Equality, 2013). These groups could influence their representatives' decision-making through internal party communications and leveraging their members' influence in areas such as selection and campaign support. This does highlight the fact that, while institutional opportunities contribute to advancing any agenda, making use of these opportunities requires interests to mould their organisations and activities to use these opportunities optimally.

\section{Legal interests}

New South Wales' De Facto Relationships Act 1984 emerged despite a lack of significant female legislative representation or leadership, and without the instigation of noninstitutional women's interest groups. The impetus for the legislation came from the legal community through a New South Wales Law Reform Commission (NSWLRC) report (Landa, 1984; Sackville et al., 1981). Sackville et al. report judges' dissatisfaction with the decisions they were forced to make in de facto relationship cases. Similar reports also prompted subsequent Australian de facto relationships legislation (Manzie, 1991, p. 1058; Sheldon, 1999). Queensland's commission (QLDLRC, 1992, pp. 2-3, 193) drew on the testimony of family lawyers and submitters principally consisting of legal organisations. The federal commission also touched on de facto relationships while reviewing matrimonial property legislation in 1987, suggesting that extending property division to de facto relationships would safeguard the institution of marriage by reducing the gap in 
responsibilities between marriage and de facto relationships (ALRC, 1987, pp. 191-192), but could not actually recommend such a change.

New Zealand's Law Commission produced similarly positive recommendations for recognising de facto relationships (NZLC, 1997), but it is difficult to claim a path-breaking role for the NZLC as with Australia. The Minister for Justice actually included de facto relationships in the original Matrimonial Proceedings Bill in 1975, but the incoming National government removed them (Atkin et al., 2013, p. 663). By 1997, the entire weight of the legal bureaucracy was working on the issue: the NZLC worked alongside the Ministry of Justice with Minister Douglas Graham's support (NZLC, 1997, p. 55). However, while the bulk of responsibility cannot be ascribed to the NZLC, the commission provided a space for large numbers of lawyers, judges, and legal academics to shape the reforms (NZLC, 1997, pp. 171-172).

American states lack similar sets of institutions for translating the legal community's pragmatism and expertise into legislative action. Attorneys-general are the leading legal actors in both federal and state governments. State attorneys-general are primarily responsible for defending the state in court and offering legal advice to the executive and legislature (Harvard Law Review, 2014, pp. 980-981), but do not lead legislative reforms as they are not legislators themselves. Additionally, state attorneys-general generally lack substantial civil service departments involved in policy development analogous to Ministries or Departments of Justice in Australasia. While they may affect relationships policies, they must use different sets of tools; both state and federal attorneys-general have expedited same-sex marriage judgements by refusing to defend legislation (Bader, 2010, p. 6; Holder, 2011).

While law revision commissions do operate in some states, their central purpose is discovering "defects and anachronisms" and recommending solutions (CALRC, 2014; Michigan Legislative Council, 2014). While this occasionally involves considering ideologically-controversial issues, much of their work involves more technical considerations. The New Jersey commission's recent work touching on relationships policy includes repealing century-old married women's property acts rendered unnecessary by the development of common law, and proposed revisions of laws that deny property settlements to a person whose spouse dies before their divorce is finalised (NJLRC, 2007, 2011). It appears that no state commission has investigated the rights of cohabitants or same-sex couples. Property matters may occasionally arise, as in a recent Connecticut study seeking greater consistency in alimony judgements (Aaron \& Schoonmaker, n.d.). Intriguingly, this 


\section{4}

study did delve into cohabitation, but only in investigating the accessibility of the present provisions for ending alimony once the recipient re-partnered (CTLRC, 2014b).

These commissions' institutional rules impose certain barriers on taking up key relationships policy issues. Legislators' involvement as commission members may restrict the issues which commissions examine and affect the recommendations they produce. While an independent commission may examine ideologically-controversial questions and provide "objective" advice, the presence of politicians and political appointees means that ideological considerations and politicians' electoral interests may subordinate the representation of legal and community interests. Moreover, commissions with uncertain or limited resources may concentrate on the important, but less controversial work of resolving defects (which bureaucrats might perform elsewhere) rather than on substantive modernisation.

Representing legal interests in the creation of relationship legislation is crucial in moving away from pro-traditionalism because legal actors - and particularly family lawyers and judges - have a unique perspective on relationships. De facto relationship property division may seem insignificant from the standpoint of 'ordinary' citizens, or even to a cohabitant (who may not consider the issue for much of the course of their relationship). Family lawyers and judges, however, may routinely encounter the issue. The QLDLRC (1992, p. 2) found that $98 \%$ of family law practitioners had encountered a de facto partner seeking legal advice in the past year, and three-quarters supported radical change. These encounters prompted support for a non-interventionist approach in which the rights and wrongs of non-marital relationships took second place to protecting the vulnerable. This perspective extends to at least some American legal actors; the American Bar Association (2014, p. 58) includes the extension of government assistance for spouses of terrorism and crime victims to unmarried partners amongst its legislative priorities, and in the states where de facto partners have received rights to property division, accident compensation, and similar "worst case" remedies, these rights developed through the courts (Bowman, 2004). 


\section{CONCLUSION}

Key elements of relationships policy in New Zealand Australia, and the United States changed significantly between 1990 and 2014. They did not, however, change evenly or (in some cases) in similar directions. This puts into question the theory presented in some singlecase policy histories that relationships policies change in response to social changes, as these differences developed despite the countries experiencing similar changes in their relationship formation patterns. Many policy actors point to demographic changes as justifications for policy change, but this does not mean that their proposed solutions are simply natural and inevitable reactions to these changes. The divergent treatment of de facto relationships demonstrates this; the prevalence of de facto relationships has increased markedly in each country, but their rights have scarcely increased in America while Australia and New Zealand have gradually equalised the status of marriage and de facto relationships. Ultimately, changes in relationship formation (or in other potentially significant aspects such as culture) are translated through historic policy institutions, by policy-makers acting under the restraints of political institutions.

The importance of electoral systems and party systems lies in how they affect the opportunities that are available to interests seeking to defend existing policies or promote new policies. These systems create veto points and agenda-setting opportunities in the policymaking process and control who has access to them. Pro-traditionalist interests can prevent non-interventionist and pro-egalitarian changes most effectively when they can divide leftwing parties and unite right-wing parties. The American and Australian systems provide a multitude of strong veto points that make legislative shifts away from pro-traditionalist policies difficult, and they allow pro-traditionalist interests access to these veto points. The local focus of candidate selection in America allows organised, motivated pro-traditionalist interests to rally behind pro-traditionalist candidates, while the ALP faction system ensures that there is a religious conservative presence within that party. In New Zealand, religious conservatives typically do not have access to these veto points, as they are excluded early in the system at candidate selection for major parties, or by diverting their attention toward minor parties.

Electoral and party systems also affect how free politicians are to follow their convictions or the preferences of their local constituencies rather than their party. When protraditionalist or pro-egalitarian interests (e.g. feminist or LGBT interests) are able to 


\section{6}

dominate debate on an issue within an Australasian party, they can use the threat of formal or informal sanctions to enforce party unity. Australasian party and electoral systems also make it more likely that representatives will focus on issues that disproportionately affect women by providing mechanisms (of varying effectiveness) for pursuing affirmative action. American representatives are less likely to be women, and can act more independently in office, because parties have much less control over who is selected to contest seats.

While political institutional arrangements may allow supporters of pro-traditionalist policies to prevent or delay changes, the strength of path dependency in relationships policy indicates that they are extremely unlikely to wrest policies back to a pro-traditionalist model once they shift. In core areas of relationships policy such as divorce law and the recognition of de facto relationships, comprehensive pro-traditionalist reforms require the removal of "rights". Even though the public might not necessarily have claimed these rights prior to their introduction, when a very different model might have been equally or more appropriate, the idea of removing them after the fact becomes a severe intervention into "private" family life. Consequently, pro-traditionalist changes typically make minor changes while reaffirming the substance of a policy. Covenant marriage, for example, allows voluntary restrictions of divorce rights, but acknowledges the rights of non-participants as valid and relieves pressure on more substantial reform. Similarly, pro-traditionalist reforms of civil partnerships in Queensland massaged the appearance of the policy into something less offensive to protraditionalists while reaffirming most of the rights of people in these partnerships.

Past policy decisions may in some situations facilitate future decisions by creating policy gaps as societies' assumptions and practices change, and creating precedents for particular changes. The treatment of cohabitants relative to spouses in each country's tax and welfare systems created different kinds of injustices (as seen by particular interests) that provided grounds for policy changes. These included de facto property reform in Australasia, but also pro-marriage tax and welfare reform in America as the arrangement of interests in power meant that only injustices against spouses were recognised. The presence of a functional approach to marriage in the Australian and New Zealand welfare systems also provided a precedent for recognising de facto relationships. It is not necessarily possible to tell how more recent policy changes will influence policy beyond 2014, however, because it is not clear what kinds of policy gaps will emerge, or how interests will use aspects of present policy as precedents for future changes. 
Legal interests are also highly influential in relationships policy-making. Strong representation of legal interests through law (reform) commissions and justice bureaucracies typically strengthens non-interventionist policies. Lawyers have a unique position in relationships policy-making because they witness perceived injustices and inefficiencies caused by gaps between policies and practices and carry weight in policy debates as learned authorities. Judicial bureaucracies also have incentives to minimise expenditure on relationship issues to free resources for other areas. Legal institutions may instigate policy changes, and their presumed political neutrality may allow governments to deflect criticism over raising controversial issues by claiming to be simply responding to their recommendations. Legal professionals also possess the expertise required to make specific recommendations on policy detail (to the point of providing draft legislation), while less expert stakeholders may only be able to supply general recommendations. Legal interests have been particularly impactful on driving change in de facto relationships policy, although it is also noteworthy that the New Zealand Ministry of Justice's preference to restrict Family Courts activity to 'essential' activities provided a basis for non-interventionist change in relationship counselling provisions.

Drawing attention to the interplay of interests within political parties, as ordered by their internal processes and electoral systems, is important in looking beyond relationships policy to other aspects of family policy. Different interests may be significant in other family policy areas - fathers' rights groups (which play a small role in eroding reconciliation support in Australia), for example, may be significant actors in debates on custody issues. However, the principle remains that in order to achieve legislative success, supporters of a policy change must in almost every case be able to command the loyalty of their party, and the rules set by that party, its leaders, and the political system control their ability to do so.

Paying attention to how institutional contexts establish the opportunities available for some of the groups that are specifically important in relationships policy debates (particularly religious conservatives and feminists) may also contribute to understanding the development of other policy areas where these groups' priorities conflict. The feminist and conservative Christian movements have extraordinarily wide-ranging interests, and often operate as movement and counter-movement. The most obvious example is abortion law which is, like same-sex marriage, a key battlefield in the American "Culture Wars", and a conscience vote issue for the main Australasian parties. Consequently, many of the factors that affect these 


\section{8}

interest's success in relationships policy development may also affect the abortion law debate.

Understanding the development of relationships policy is also important because aspects of relationships policy will affect the development of other policy areas. This may potentially occur through a reactive form of path dependency, as aspects of relationships policy may affect patterns of relationship formation, affecting the number of people in need of government support, exacerbating or relieving pressure on government services and potentially forcing policy changes. Indeed Republicans have occasionally offered this as a reason for rejecting same-sex marriage (Strach, 2007, p. 1). Adopting functionalist definitions of relationships may also affect areas such as immigration policy, expanding the pool of possible eligible immigrants, with knock-on effects for fields such as housing and healthcare.

The role of legal interests in the development of relationships policy is also potentially significant for the study of other aspects of family policy. Lawyers and judges are significant actors in debates over issues such as custody determination, child support and youth justice. These are issues that - like de facto relationships (and, in some cases, because of de facto relationships) are increasingly important in contemporary society. They are also issues in which lawyers and judges have a stake as participants in and beneficiaries of policy administration, and as witnesses to perceived injustices and inefficiencies. The influence of legal interests also extends beyond Western liberal democracies. My previous work on Malaysia and Singapore, which found that Ahmad Ibrahim played a key role in Islamic family law reform as Attorney-General of both countries (at different times), suggests that the institutionalised representation of legal interests at least offers the opportunity for lawyers and judges to influence policy-making in a range of societies.

The extent of variation between Australia, New Zealand and the United States on relationships policy issues suggests that the idea that these three countries share a common approach to family policy is significantly flawed. Significant differences have emerged between the countries in terms of regulation, and the different approaches that the American and Australasian tax and welfare systems take to the role of marriage and relationships in determining obligations and entitlements have become further entrenched. Attempts to assess the state of "family policy" need to work from a well-rounded picture of state interventions into the family rather than concentrating exclusively or near-exclusively on issues relating to children and parenting. 
For all that adult intimate relationships are often considered a private issue in Western liberal democracies, they have also been the subject of a considerable amount of public contestation over the past twenty-five years. Changes in the ways in which governments intervene in the relationships of their citizens are not simply the inevitable outcome of changing patterns of relationships. Rather, they are the outcomes of contestations of values, assumptions and priorities, played out within institutional environments that shape both the opportunities available to the holders of these values, assumptions and priorities, and the policies they can pursue. 


\title{
REFERENCES
}

\section{LEGISLATIVE REFERENCES}

\author{
New Zealand
}

Civil Union Act 2004 (No. 102)

Crimes Act 1961 (No. 43)

Family Proceedings Act 1980 (No. 94)

Family Proceedings Amendment Act 1994 (No. 32)

Family Proceedings Amendment Act (No 2) 2013 (No. 80)

Human Rights Act 1993 (No. 82)

Human Rights Amendment Act 2001

Interpretation Act 1999 (No. 85)

Land and Income Assessment Act, 1891 (No. 18)

Marriage Act 1955 (No. 92)

Marriage (Definition of Marriage) Amendment Act 2013 (No. 20)

Matrimonial Property Act 1976 (No. 166) [later Property (Relationships) Act]

Property (Relationships) Amendment Act 2001 (No. 5)

Relationships (Statutory References) Act 2005 (No. 3)

Relationships (Statutory References) Bill 2004

Social Security Act, 1964 (No. 136)

Status of Children Act 1969 (No. 18)

Taxation (Income-sharing Tax Credit) Bill, 2010

\section{Australia}

\section{Commonwealth}

Commonwealth of Australia Constitution Act 1900

Family Law Act 1975 (No. 53)

Family Law Amendment Act 1983 (No. 72)

Courts (Mediation and Arbitration) Act 1991 (No. 113)

Family Law Amendment Act 1991 (No. 159)

Family Law Reform Act 1995 (No. 167)

Family Law Reform Bill 1994 [No. 2]

Family Law Amendment (Shared Parental Responsibility) Act 2006 (No. 46) 


\section{1}

Family Law Amendment (De Facto Financial Matters and Other Measures) Act 2008 (No. 115)

Income Tax Assessment Act, 1913 (No. 41)

Marriage Act 1961 (No. 12)

Marriage Amendment Act 2002 (No. 77)

Marriage Amendment Act 2004 (No. 126)

Matrimonial Causes Act 1959 (No. 104)

Sex Discrimination Amendment Act 1991 (No. 71)

Social Security Act 1991 (No. 46)

\section{ACT}

Domestic Relationships Act 1994 (No. 28)

Civil Union Act 2012 (No. 40)

Marriage Equality (Same-Sex) Act 2013 (No. 39)

\section{New South Wales}

De Facto Relationships Act 1984 (No. 147) [now Property (Relationships) Act]

Property (Relationships) Legislation Amendment Act 1999 (No. 4)

\section{Queensland}

Aboriginals Protection and Restriction of the Sale of Opium Act 1897

Property Law Amendment Act 1999 (No. 89)

Civil Partnerships Act 2011 (No. 46)

Civil Partnerships and Other Legislation Amendment Act 2012 (No. 12)

\section{Tasmania}

Relationships Act 2003 (No. 44)

\section{Victoria}

Aborigines Protection Act 1869 [An Act to provide for the Protection and Management of the Aboriginal Natives of Victoria]

Statute Law Amendment (Relationships) Act 2001 (No. 27) 


\section{United States}

\section{Federal}

Constitution of the United States

Defence of Marriage Act, 1996, Pub. L. 104-199

Deficit Reduction Act of 2005, Pub. L. 109-171

Economic Growth and Tax Relief Reconciliation Act of 2001, Pub. L. 107-16

Marriage Tax Relief Reconciliation Act of 2000, H.R. 4810

Personal Responsibility and Work Opportunity Reconciliation Act of 1996, Pub. L. 104-193.

United States Code Title 42

\section{Arizona}

Arizona Revised Statutes, Title 25

\section{Arkansas}

Arkansas Code, Title 9

\section{California}

California Family Code

\section{Georgia}

Official Code of Georgia, Title 19

Hawai'i

Constitution of the State of Hawai' $i$

Hawai'i Revised Statutes, Title 31

\section{Louisiana}

Louisiana Revised Statutes, Title 9

Act No. 1380, 1997

Act No. 490, 2004

Kansas

Kansas Statutes, Chapter 23

\section{New Jersey}

New Jersey Statutes, Title 37

Act No. 6, 2007

\section{New York}

New York Domestic Relations Code

New York Family Court Act

\section{Oklahoma}

Oklahoma Statutes, Title 43

SB882, 2004

\section{Texas}

Texas Family Code

\section{Vermont}

Vermont Statutes, Titles 15 \& 18

Act No. 92, 2012

\section{Wisconsin}

Wisonsin Statutes, §765-770 


\section{OTHER REFERENCES}

AAP. (2005, August 1). Relationship centres “to help families resolve disputes." Retrieved July 11, 2014, from http://www.smh.com.au/news/national/relationship-centres-tohelp-families-resolve-disputes/2005/07/31/1122748520819.html

AAP. (2006, June 15). Anger as gay civil union ban upheld. Retrieved September 7, 2014, from http://www.smh.com.au/news/national/anger-as-gay-civil-union-banupheld/2006/06/15/1149964653749.html

Aaron, B., \& Schoonmaker, S. V. (n.d.). Alimony: Past Present and Future. CALRC. Retrieved from http://www.cga.ct.gov/lrc/Alimony/Final\%20without\%20quote.pdf

ABC News. (2011, December 5). Labor divided after gay marriage backing. Retrieved June 10, 2014, from http://www.abc.net.au/news/2011-12-04/labor-divided-on-gaymarriage-approval/3711332

Abjorensen, N. (2008). John Howard and the conservative tradition. North Melbourne, Vic: Australian Scholarly Pub.

ABS. (1974). Official year book of Australia: No. 60, 1974. Canberra: ABS.

ABS. (1997). Australian Social Trends: 1997. Canberra, ACT: ABS. Retrieved from http://www.abs.gov.au/AUSSTATS/free.nsf/log?openagent\&41020_1997.pdf\&4102. 0\&Publication\&3105281F7F04C4ACCA25722500049550\&0\&1997\&19.06.1997\&P revious

ABS. (2008). 3105.0.65.001 Australian Historical Population Statistics, 2008. Canberra, $\begin{array}{lll}\text { ACT: } & \text { ABS. } & \text { Retrieved }\end{array}$ http://www.abs.gov.au/AUSSTATS/abs@.nsf/DetailsPage/3105.0.65.0012008?Open Document 


\section{4}

ABS. (2009). Australian Social Trends: March 2009. Belconnen, ACT: ABS. Retrieved from http://www.ausstats.abs.gov.au/Ausstats/subscriber.nsf/0/9B47C077B3B6C1 AECA25 75830015F1CF/\$File/41020_ast_march2009.pdf

ABS. (2011). MDCP by STATE and INGP; Counting: Persons, Place of Usual Residence. ABS.

ABS. (2012). Australian Social Trends: March 2012. ABS. Retrieved from http://www.abs.gov.au/AUSSTATS/subscriber.nsf/log?openagent\&41020_astmar201 2.pdf\&4102.0\&Publication\&701575637CC4BBE3CA2579CE000BB833\&\&March\% 20Quarter\%202012\&04.04.2012\&Previous

ABS. (2013). 3310.0 - Marriages and Divorces, Australia, 2012: Divorces. Retrieved July 16, 2014 from http://www.abs.gov.au/AUSSTATS/abs@.nsf/DetailsPage/3310.02012?OpenDocume nt

ACL. (2014a). Marriage Facts. ACL. Retrieved from http://www.acl.org.au/wpcontent/uploads/2014/07/FactSheet_v02d.pdf

ACL. (2014b). Protecting the Unborn. ACL. Retrieved from http://www.acl.org.au/wpcontent/uploads/2014/06/acl_factsheet_singles_print-5.pdf

AIFS. (2014). Family Facts and Figures: Marriage. Retrieved June 11, 2014, from http://www.aifs.org.au/institute/info/charts/marriage/index.html

ALP. (2011). National Platform: 46th National Conference. Australian Labor Party. Retrieved from http://d3n8a8pro7vhmx.cloudfront.net/australianlaborparty/pages/121/attachments/ori ginal/1365135867/Labor_National_Platform.pdf?1365135867 
ALRC. (1987). Matrimonial Property (No. 39). Canberra: ALRC. Retrieved from http://www.alrc.gov.au/about

ALRC. (2014). About. Retrieved December 1, 2014, from http://www.alrc.gov.au/about

American Bar Association. (2014). Legislative Priorities. American Bar Association. $\begin{array}{ll}\text { Retrieved } & \text { from }\end{array}$ http://www.americanbar.org/content/dam/aba/uncategorized/GAO/legislativeissueslist .authcheckdam.pdf

Andrews, K. (2014). Enhancing prevention and early interventions: Opening address at the Family \& Relationship Services Australia National Conference. Retrieved November 6, 2014, from http://kevinandrews.com.au/latest-news/2014/11/04/enhancingprevention-early-intervention-opening-address-family-relationship-services-australianational-conference/

Arizona LGBT Caucus. (2013). About the LGBT Caucus. Retrieved December 5, 2014, from http://www.azlgbtdems.org/content/about-lgbt-caucus

Arts, W., \& Gelissen, J. (2002). Three worlds of welfare capitalism or more? A state-of-theart report. Journal of European Social Policy, 12(2), 137-158.

Association of Family and Conciliation Courts. (2014). History. Retrieved August 20, 2014, from http://www.afccnet.org/about/history

Atkin, B., Caldwell, J., Henaghan, M., \& Tapp, P. (2013). Fifty Years of New Zealand Family Law. New Zealand Universities Law Review, 25(4), 645-666.

Attorney-General's Department. (2010). Implementation of the Family Relationship Centres Initiative (No. 1). Barton, ACT: Attorney-General's Department. Retrieved from http://www.anao.gov.au/ /media/Uploads/Documents/2010\%2011\%20audit\%20repor t\%20no\%201.pdf 
Auchmuty, R. (2012). Law and the Power of Feminism: How Marriage Lost its Power to Oppress Women. Feminist Legal Studies, 20(2), 71-87. doi:10.1007/s10691-0129197-6

Australian Marriage Equality. (2014a). About Us. Retrieved December 5, 2014, from http://www.australianmarriageequality.org/about/

Australian Marriage Equality. (2014b). Coalition MP \& Senators Submission. Retrieved December 8, 2014, from http://www.australianmarriageequality.org/federal-coalitionmp-contact-form/

Bader, H. (2010). The Nation's Worst State Attorneys General. Washington, DC: Competitive Enterprise Institute.

Baldwin, T. S. G. (2006, July 18). Marriage Protection Amendment. Congressional Record: Proceedings and Debates of the 109th Congress, Second Session, 152(94), H5292H5293.

Barnes, S. (2014, May 9). Arkansas judge strikes down state ban on same-sex marriage. Retrieved September 10, 2014, from http://www.reuters.com/article/2014/05/09/ususa-gaymarriage-arkansas-idUSBREA480VB20140509

Baskerville, S. (2006). Politics and Same-Sex Marriage. Society, 44(1), 60-66.

Batten, D. (Ed.). (2010). Domestic Partnership Law. In Gale Encyclopedia of American Law (3rd ed., Vol. 3, p. 532). Detroit: Gale.

BDM Tasmania. (2014). Ceremonies. Retrieved September 7, 2014, from http://www.justice.tas.gov.au/bdm/relationships/ceremonies

Bearup, G. (2014, May 17). Why does Kevin Andrews want to give couples a helping hand? $\begin{array}{llll}\text { Retrieved } & \text { September } & 8, & 2014,\end{array}$ 
http://www.theaustralian.com.au/news/features/why-does-kevin-andrews-want-togive-couples-a-helping-hand/story-e6frg8h6-1226915797400

Benson-Pope, D. (2004, June 24). Relationships (Statutory References) Bill: First Reading. In New Zealand Parliamentary Debates (Vol. 618, pp. 13951-13593).

Berrick, J. D. (2005). Marriage, Motherhood and Welfare Reform. Social Policy and Society, 4(2), 133-145. doi:10.1017/S1474746404002271

Bianco, W. T., \& Canon, D. T. (2011). American politics today (Core 2nd ed). New York: W. W. Norton \& Co.

Bishop, B. K. (2008, August 28). Family Law Amendment (De Facto Financial Matters and Other Matters) Bill 2008 - Second Reading. In Cth. Parliamentary Debates, House of Representatives (Vol. 10, pp. 6521-6525).

Bitler, M. P., Gelbach, J. B., Hoynes, H. W., \& Zavodny, M. (2004). The impact of welfare reform on marriage and divorce. Demography, 41(2), 213-236.

Blanchfield Nicholls Partners. (2008). The Referral of De Facto Financial Matters to the Family Law Act. A Uniform Approach?. Blanchfield Nicholls Partners. Retrieved from http://www.bnplaw.com.au/pdf/The_Referral_of_De_Facto_Financial_Matters_to_th e_Family_Law_Act.pdf

Bowman, C. G. (2004). Legal Treatment of Cohabitation in the United States. Law \& Policy, 26(1), 119-151.

Bradbury, J. C., \& Crain, W. M. (2001). Legislative organization and government spending: cross-country evidence. Journal of Public Economics, 82(3), 309-325. doi:10.1016/S0047-2727(00)00150-X 
Bradford, J. W. (1994, November 9). Family Law Reform Bill 1994 [No. 2] - Second Reading. In Cth. Parliamentary Debates, House of Representatives (Vol. 197, pp. 2883-2887).

Bradley, W. W. (1996, August 1). Personal Responsibility and Work Opportunity Reconciliation Act of 1996 - Conference Report. Congressional Record, 142(116), S9366-S9367.

Brett, J. (2003). The Australian liberals and the moral middle class: from Alfred Deakin to John Howard. Cambridge ; New York: Cambridge University Press.

Brown, R. (1991, March 6). Sex Discrimination Amendment Bill, Second Reading. In Cth. Parliamentary Debates, House of Representatives (Vol. 176, pp. 1411-1417). Commonwealth of Australia.

Brozovsky, J., \& Cataldo, A. J. (1994). A Historical Analysis of the "Marriage Tax Penalty." The Accounting Historians Journal, 21(1), 163-187.

Bruce, S. (2003). Religion. In R. Singh (Ed.), Governing America: the politics of a divided democracy (pp. 410-427). Oxford ; New York: Oxford University Press.

Bumpass, L. L., \& Sweet, J. A. (1989). National Estimates of Cohabitation. Demography, 26(4), 615-625.

Bush-Cheney. (2000). George W. Bush for President Official Site: Issues. Retrieved $\begin{array}{llll}\text { November } & 18, & 2014, & \text { from }\end{array}$ http://webarchive.loc.gov/lcwa0007/20001112173216/http://www.georgewbush.com/i ssues/taxes.html

CALRC. (2014). History and Purpose. Retrieved December 1, 2014, from http://www.clrc.ca.gov/Menu5_about/history.html 
Castles, F. G. (1996). Needs-Based Strategies of Social Protection in Australia and New Zealand. In G. Esping-Andersen (Ed.), Welfare States in Transition: National Adaptations in Global Economies (pp. 88-115). London; Thousand Oaks; New Dehli: SAGE Publications Ltd.

Catholic Health Association. (n.d.). Participating in Congressional Hearings. Retrieved December 1, 2014, from https://www.chausa.org/Advocacy/effective-legislativeadvocacy/building-an-action-plan/participating-in-congressional-hearings

CDC. (2010). Marriage and Cohabitation in the United States (No. 23-28). Hyattsville, MD:

CDC. Retrieved from http://www.cdc.gov/nchs/data/series/sr_23/sr23_028.pdf

CDC. (2013a). Divorce rates by State: 1990, 1995, and 1999-2011. Retrieved August 14, 2014, from http://www.cdc.gov/nchs/data/dvs/marriage_rates_90_95_99-11.pdf

CDC. (2013b). Marriage rates by State: 1990, 1995, and 1999-2011. Retrieved August 14, 2014, from http://www.cdc.gov/nchs/data/dvs/marriage_rates_90_95_99-11.pdf

CDC. (2013c). National Marriage and Divorce Rate Trends. Retrieved July 24, 2014, from http://www.cdc.gov/nchs/nvss/marriage_divorce_tables.htm

Chappell, L., \& Costello, M. (2011). Australian Federalism and Domestic Violence PolicyMaking. Australian Journal of Political Science, 46(4), 633-650. doi:10.1080/10361146.2011.623663

Charron, S. (2000). Baker v. Vermont, 744 A.2d 864 (Vt. 1999). American University Journal of Gender, Social Policy \& the Law, 8(2), 567-573.

Cheng, D. (2014, August 26). Disclosures disgust defeated candidate. Retrieved October 30, 2014 , from http://www.nzherald.co.nz/nz/news/article.cfm?c_id=1\&objectid=11314137 
Christian Coalition. (1996). Agreement with New Zealand. Wellington: Christian Coalition.

Christian Democrats. (1996). Christian Democrats and Home Schoolers. Keystone: The Journal of Christian Home Schoolers of New Zealand, 2(1), 17-19.

Clark, H., \& Dunne, P. (2002). Agreement for Confidence and Supply between the Labour/Progressive Government and the United Future Parliamentary Caucus.

Clark, H., \& Dunne, P. (2005). Confidence and Supply Agreement with United Future.

CNN. (2004). Election 2004 - Ballot Measures. Retrieved September 10, 2014, from http://edition.cnn.com/ELECTION/2004/pages/results/ballot.measures/

Collins, J. (2013, July 2). Family Court Proceedings Reform Bill: Second Reading. In New Zealand Parliamentary Debates (Vol. 691, pp. 11536-7).

Connolly, T. (1994, April 12). Domestic Relationships Bill 1994. In ACT Legislative Assembly Debates (pp. 1116-1120).

Conservative Party. (2014). Issues. Retrieved July 22, 2014, from http://www.conservativeparty.org.nz/index.php?page=Issues

Copen, C. E., Daniels, K., Mosher, W. D., \& Division of Vital Statistics. (2013). First Premarital Cohabitation in the United States: 2006-2010 National Survey of Family Growth (No. 64). Hyattsville, MD: CDC.

Costello, P. (1996, August 20). Budget Speech 1996-97. Retrieved September 9, 2014, from http://www.budget.gov.au/1996-97/speech.asp

Cox, B. J. (1994). Same-Sex Marriage and Choice-of-Law: If We Marry in Hawaii, Are We Still Married When We Return Home. Wisconsin Law Review, 1994(5), 1033-1118. 
Crook, A. (2009a, September 30). How to become a federal MP. Part 1, the ALP. Retrieved October 29, 2014, from http://www.crikey.com.au/2009/09/30/special-report-how-tobecome-a-federal-mp-part-1-alp/

Crook, A. (2009b, October 1). How to become a federal MP. Part 2, the Libs. Retrieved October 29, 2014, from http://www.crikey.com.au/2009/10/01/how-to-become-afederal-mp-part-2-the-libs/

Croome, R. (2010, May 17). NSW squibs on relationship recognition. Retrieved June 22, 2014, from http://www.smh.com.au/federal-politics/political-opinion/nsw-squibs-onrelationship-recognition-20100517-v8ax.html

CTLRC. (2014a). Connecticut Law Revision Commission. Retrieved December 1, 2014, from http://www.cga.ct.gov/lrc/

CTLRC. (2014b). Study committee regarding alimony statutes: meeting minutes. Hartford: CTLRC.

CWfA. (2014). Who We Are. Retrieved November 3, 2014, from http://www.cwfa.org/about/who-we-are/

Daly, R. (2009, January 5). Women's Caucus Puts Health at Top of Its '09 List. Retrieved November 3, 2014, from http://womensenews.org/story/washingtonoutlookcongresswhite-house/090105/womens-caucus-puts-health-at-top-its-09list\#.VFf7YvmUdqU

Department of Social Services. (2014). Stronger Relationships Trial. Retrieved September 8, 2014, from http://www.dss.gov.au/our-responsibilities/families-andchildren/programs-services/stronger-relationships-trial 
Department of Statistics. (1988). Marriage and Marriage Dissolution. In The April Report: Report of The Royal Commission on Social Policy (Vol. 1, pp. 136-142). Wellington: Government Printer.

Department of the Senate. (2014). Senate Committees. Department of the Senate. Retrieved from

http://www.aph.gov.au/ /media/05\%20About\%20Parliament/52\%20Sen/523\%20PPP /Senate\%20Briefs/PDFs/brief04.pdf

DHS. (2014a). Family Tax Benefit. Retrieved May 7, 2014, from http://www.humanservices.gov.au/customer/services/centrelink/family-tax-benefitpart-a-part-b

DHS. (2014b). Income test for Newstart Allowance, Partner Allowance, Sickness Allowance and Widow Allowance. Retrieved October 8, 2014, from http://www.humanservices.gov.au/customer/enablers/income-test-allowances

Dinan, J. (2011). State Constitutional Amendment Processes and the Safeguards of American Federalism. Penn State Law Review, 115(4), 1007-1034.

DNC. (2012). The Charter \& the Bylaws of the Democratic Party of the United States. DNC.

Doherty, W. J., \& Anderson, J. R. (2004). Community Marriage Initiatives. Family Relations, $53(5), 425-432$.

Domenici, P. V. (1996, August 1). Personal Responsibility and Work Opportunity Reconciliation Act of 1996 - Conference Report. Congressional Record, 142(116), S9322-S9323.

Edwards, B. (2003). Political Parties in New Zealand: A Study of Ideological and Organisational Transformation (Doctoral Thesis). University of Canterbury, Christchurch. 
Elliott, D. B., Krivickas, K., Brault, M. W., \& Kreider, R. M. (2012). Historical Marriage Trends from 1890-2010: A Focus on Race Differences. Presented at the Population Association of America, San Francisco, CA. Retrieved from http://www.census.gov/hhes/socdemo/marriage/data/acs/ElliottetalPAA2012paper.pdf

EMILY's List. (2014). What We Do. Retrieved November 3, 2014, from http://www.emilyslist.org/pages/entry/what-we-do

EMILY's List (Australia). (2014). Our History. Retrieved November 4, 2014, from https://www.emilyslist.org.au/about-us/our-history

English, B. A., \& King, R. J. R. (1983). Families in Australia. Kensington, N.S.W.: Family Research Unit, University of New South Wales.

Ernst, J. L. (2006). The Congressional Caucus for Women's Issues: an inside perspective on lawmaking by and for women. Michigan Journal of Gender \& Law, 12(2), 189-274.

Espenshade, T. J. (2005). Marriage trends in america: Estimates, implications, and underlying causes. Population and Development Review, 11(2), 193-245.

Esping-Andersen, G. (1990). The Three Worlds of Welfare Capitalism. Cambridge: Polity Press.

Esping-Andersen, G. (1999). Social Foundations of Postindustrial Economies. Oxford: Oxford University Press.

Ezrow, L. (2011). Electoral Systems and Party Responsiveness. In N. Schofield \& G. Caballero (Eds.), Political Economy of Institutions, Democracy and Voting (pp. 303325). Berlin, Heidelberg: Springer Berlin Heidelberg. Retrieved from http://link.springer.com/10.1007/978-3-642-19519-8_12 
Faircloth, D. M. (1996, August 1). Personal Responsibility and Work Opportunity Reconciliation Act of 1996 - Conference Report. Congressional Record, 142(116), S9366.

Family First NZ. (2006). Introducing the Family First Lobby. Retrieved October 30, 2014, from https://www.familyfirst.org.nz/2006/03/introducing-the-family-first-lobby/

Farrell, D. M., \& McAllister, I. (2006). The Australian electoral system: origins, variations, and consequences. Sydney: UNSW Press.

Feldman, W. (1999, December 9). Property Law Amendment Bill - Second Reading. In Qld. Legislative Assembly Debates (pp. 6275-6278). Retrieved from http://www.parliament.qld.gov.au/documents/hansard/1999/991209ha.pdf

Ferguson, D., Stein, J., \& Silverstein, J. (2014, August 1). Wisconsin Supreme Court upholds state's domestic partner registry. Retrieved September 1, 2014, from http://www.jsonline.com/news/statepolitics/wisconsin-supreme-court-upholds-statesdomestic-parter-registry-b99321113z1-269364021.html

Finlay, H. (1974). The Family and the Law. In J. Krupinski \& A. Stoller (Eds.), The Family in Australia: Social, Demographic and Psychological Aspects (pp. 83-100). Rushcutter's Bay, NSW: Pergamon Press (Australia) Ltd.

Fitzgerald, R. (2014, June 7). The major threat of minor parties in new Senate. Retrieved October 29, 2014, from http://www.theaustralian.com.au/opinion/columnists/themajor-threat-of-minor-parties-in-new-senate/story-e6frg7eo-1226946409257

Foley, M. (1999, December 9). Property Law Amendment Bill - Committee. In Qld. Legislative Assembly Debates (pp. 6283-6284). Retrieved from http://www.parliament.qld.gov.au/documents/hansard/1999/991209ha.pdf 


\section{5}

Francis, S. (2014, June 13). Unmarried Cohabitants' Benefits. Retrieved October 6, 2014, from http://www.peoples-law.org/unmarried-cohabitants-benefits

Franks, S. (2004, June 24). Relationships (Statutory References) Bill: First Reading. In New Zealand Parliamentary Debates (Vol. 618, pp. 13958-13960).

Freedom to Marry. (2014). About Freedom to Marry. Retrieved December 8, 2014, from http://www.freedomtomarry.org/pages/about-us

Freeman, M. D., \& Lyon, C. M. (1983). Cohabitation Without Marriage. Aldershot: Gower Publishing Company Limited.

Garrison, M. (2008). Nonmarital Cohabitation: Social Revolution and Legal Regulation. Family Law Quarterly, 42(3), 309-331.

Garrison, M., \& Scott, E. S. (2012). Legal Regulation of Twenty-First-Century Families. In M. Garrison \& E. S. Scott (Eds.), Marriage at the Crossroads: Law, Policy, and the Brave New World of Twenty-First-Century Families (pp. 303-326). New York, NY: Cambridge University Press.

Gauthier, A. H. (1996). The State and the Family: A Comparative Analysis of Family Policies in Industrialised Countries. Oxford: Clarendon Press.

Gay \& Lesbian Rights Lobby. (2009). What We Do. Retrieved December 8, 2014, from http://glrl.org.au/index.php/About-Us/About-Us/What-We-Do

Gerring, J. (2008). Case selection for case-study analysis: qualitative and quantitative techniques. In J. M. Box-Steffensmeier, H. E. Brady, \& D. Collier (Eds.), The Oxford handbook of political methodology (pp. 645-684). Oxford; New York: Oxford University Press. 
GLAAD. (2014). About GLAAD. Retrieved December 8, 2014, from http://www.glaad.org/about

GLAD. (2008). Case of the Month - November. Retrieved December 7, 2014, from http://www.glad.org/30years/case_nov.html

GLAD. (2013). Pedersen et al. v. Office of Personnel Management et al. Retrieved December 7, 2014, from http://www.glad.org/work/cases/pedersen-v-opm

Glennon, L. (2008). Obligations between adult partners: moving from form to function. International Journal of Law, Policy and the Family, 22(1), 22-60.

Goldberg, C. (2000, March 17). Vermont's House backs wide rights for gay couples. Retrieved August 21, 2014, from http://www.nytimes.com/2000/03/17/us/vermont-shouse-backs-wide-rights-for-gay-couples.html

Gore-Lieberman. (2000). Al Gore's Issues: America's Working Families. Retrieved

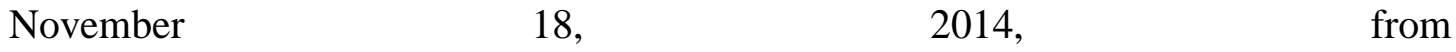
http://webarchive.loc.gov/lcwa0007/20001107032509/http://algore.com/economy/eco _accomp2.html

Gough, I. (2004). East Asia: the limits of productivist welfare regimes. In I. Gough \& G. Wood (Eds.), Insecurity and Welfare Regimes in Asia, Africa and Latin America: Social Policy in Development Contexts (pp. 49-87). Cambridge: Cambridge University Press.

GovTrack. (2014a). H.R. 3396 (104th): Defense of Marriage Act (On Passage of the Bill) [House Vote \#316]. Retrieved July 30, 2014, from https://www.govtrack.us/congress/votes/104-1996/h316 


\section{7}

GovTrack. (2014b). H.R. 3396 (104th): Defense of Marriage Act (On Passage of the Bill) [Senate Vote \#280]. Retrieved July 30, 2014, from https://www.govtrack.us/congress/votes/104-1996/s280

Grassley, C. E. (2005, November 17). Tax Relief Act of 2005. Congressional Record, 151(153), S13094-S13095; S13125.

Graycar, R. (2012). Family Law Reform in Australia, or Frozen Chooks Revisited Again? Theoretical Inquiries in Law, 13(1), 241-269.

Haider-Markel, D. P. (2003). Gay rights. In R. Singh (Ed.), Governing America: the politics of a divided democracy (pp. 428-448). Oxford; New York: Oxford University Press.

Halford, W. K., \& van Acker, E. (2012). Are Governments and Marriage Strange Bedfellows? In P. Noller \& G. C. Karantzas (Eds.), The Wiley-Blackwell Handbook of Couples and Family Relationships (pp. 453-466). Malden, MA; Oxford; Chichester: Blackwell Publishing Ltd.

Hantrais, L. (1994). Comparing Family Policy in Britain, France and Germany, 23(2), 135160.

Hantrais, L. (2004). Crossing cultural boundaries. In P. Kennett (Ed.), A Handbook of Comparative Social Policy (pp. 261-275). Cheltenham; Northampton, MA: Edward Elgar Publishing.

Harrison, M. (1991). The legal system and de facto relationships. Family Matters, 30, 30-33.

Harrison, M. (2002). Australia's Family Law Act: The First Twenty-Five Years. International Journal of Law, Policy and the Family, 16(1), 1-21. doi:10.1093/lawfam/16.1.1 


\section{8}

Hart, V. (2003). Gender. In R. Singh (Ed.), Governing America: the politics of a divided democracy (pp. 391-409). Oxford ; New York: Oxford University Press.

Harvard Law Review. (2014). Appointing state attorneys general: evaluating the unbundled state executive. Harvard Law Review, 127(3), 973-994.

Heard, G. (2006). Pronatalism Under Howard. People and Place, 14(3), 12-25.

Heard, G. (2011). Socioeconomic Marriage Differentials in Australia and New Zealand. Population and Development Review, 37(1), 125-160.

Heclo, H. (1974). Modern Social Policies in Britain and Sweden: From Relief to Income Maintenance. New Haven; London: Yale University Press.

Heidenheimer, A. J. (1973). The Politics of Public Education, Health and Welfare in the USA and Western Europe: How Growth and Reform Potentials Have Differed. British Journal of Political Science, 3(3), 315-340. doi:10.2307/193455

Henaghan, M., \& Tapp, P. (1992). Legally Defining the Family. In M. Henaghan \& W. R. Atkin (Eds.), Family law policy in New Zealand (pp. 1-53). Auckland; New York: Oxford University Press.

Herger, W. W. (2001, November 13). Promoting Safe and Stable Families Amendments of 2001. Congressional Record, 147(156), H8091-H8092.

Hickey, M. (1991, August 13). De Facto Relationships Bill (Serial 42) - Second reading. In NT Parliamentary Record (Vol. 4, pp. 1384-1385). Retrieved from http://notes.nt.gov.au/lant/hansard/HANSARD6.NSF/0044d01ca7b2aec748255fcd002 4659c/412e18590c7329016925729c001b5628?OpenDocument 
High Court of Australia. The Commonwealth v Australian Capital Territory 2013 HCA 55 (High Court of Australia December 12, 2013). Retrieved from http://www.austlii.edu.au/au/cases/cth/HCA/2013/55.html

Hodder-Williams, R. (2003). The federal judiciary. In R. Singh (Ed.), Governing America: the politics of a divided democracy (pp. 147-168). Oxford; New York: Oxford University Press.

Hodgson, G. M. (2006). What Are Institutions? Journal of Economic Issues, 40(1), 1-25. doi:10.2307/4228221

Holder, E. (2011). Letter from the Attorney General to Congress on Litigation Involving the Defense of Marriage Act. Retrieved December 3, 2014, from http://www.justice.gov/opa/pr/letter-attorney-general-congress-litigation-involvingdefense-marriage-act

House of Representatives Standing Committee on Social Policy and Legal Affairs. (2012). Advisory report: Marriage Equality Amendment Bill 2012 and Marriage Amendment Bill 2012. Canberra: The Parliament of the Commonwealth of Australia. Retrieved from http://www.aph.gov.au/Parliamentary_Business/Committees/House_of_Representativ es_Committees?url=spla/bill\%20marriage/report/final.pdf

Human Rights Campaign. (2014). Our Victories. Retrieved December 8, 2014, from http://www.hrc.org/the-hrc-story/our-victories

Humphries, G. (1994, May 19). Domestic Relationships Bill 1994. In ACT Legislative Assembly Debates (pp. 1800-1805). 


\section{0}

Hurst, D. (2011, November 30). Queensland's civil unions debate blow by blow. Retrieved September 7, 2014, from http://www.brisbanetimes.com.au/queensland/queenslandscivil-unions-debate-blow-by-blow-20111130-1o6rd.html

Hurst, D. (2012, June 20). Darling, will you register me? Retrieved June 25, 2014, from http://www.brisbanetimes.com.au/queensland/darling-will-you-register-me20120620-20o78.html

IRS. (2013). Treasury and IRS Announce That All Legal Same-Sex Marriages Will Be Recognized For Federal Tax Purposes. Retrieved August 25, 2014, from http://www.irs.gov/uac/Newsroom/Treasury-and-IRS-Announce-That-All-LegalSame-Sex-Marriages-Will-Be-Recognized-For-Federal-Tax-Purposes\%3B-RulingProvides-Certainty,-Benefits-and-Protections-Under-Federal-Tax-Law-for-Same-SexMarried-Couples

Jain, S., \& Kurz, K. (2007). New Insights on Preventing Child Marriage: A Global Analysis of Factors and Programs. Washington, DC: International Center for Research on Women. Retrieved from https://www.icrw.org/files/publications/New-Insights-onPreventing-Child-Marriage.pdf

Johnson, M. D. (2012). Healthy marriage initiatives: On the need for empiricism in policy implementation. American Psychologist, 67(4), 296-308. doi:10.1037/a0027743

Jones, C. (1985). Patterns of Social Policy: An introduction to Comparative Analysis. London; New York: Tavistock Publications.

Jones, D. (2004a, June 24). Civil Union Bill: Second Reading. In New Zealand Parliamentary Debates (Vol. 622, pp. 17392-17394).

Jones, D. (2004b, December 2). Relationships (Statutory References) Bill: First Reading. In New Zealand Parliamentary Debates (Vol. 618, pp. 13956-13957). 


\section{1}

Judicial Branch of Arizona Pinal County. (2014). Conciliation Court - FAQ. Retrieved

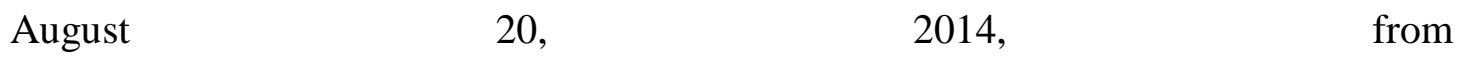

http://www.pinalcountyaz.gov/Departments/ConciliationCourt/Pages/FAQ.aspx\#2009 $-03-18$ 09:53:56

Juvenile Justice \& Family Issues Committee. (1999, April 12). Witness List: HB 2442. $\begin{array}{llll}\text { Retrieved } & \text { August } & 6, & 2014,\end{array}$ http://www.capitol.state.tx.us/tlodocs/76R/witlistbill/html/HB02442H.htm

Kagan, R. A. (2004). American Courts and the Policy Dialogue: The Role of Adversarial Legalism. In M. C. Miller \& J. Barnes (Eds.), Making policy, making law: an interbranch perspective (pp. 13-34). Washington, D.C: Georgetown University Press.

Karvelas, P. (2013, April 25). Rainbow Labor's gay-marriage push. Retrieved December 5, 2014, from http://www.theaustralian.com.au/national-affairs/rainbow-labors-gaymarriage-push/story-fn59niix$1226629010445 ? \mathrm{nk}=9 \mathrm{f} 22 \mathrm{de} 2147$ eeefb656f3c5e58b39b52b

Kennedy, E. (1996, September 10). Defence of Marriage Act - Third Reading. Congressional Record, 142(123), S10101-10102.

Kennett, P. (2004). Constructing categories and data collection. In P. Kennett (Ed.), A Handbook of Comparative Social Policy (pp. 292-306). Cheltenham; Northampton, MA: Edward Elgar Publishing.

Keremidchieva, Z. (2012). Legislative Reform, the Congressional Caucus for Women's Issues, and the Crisis of Women's Political Representation. Women \& Language, 35(1), 13-38. 


\section{2}

Kerr, C. (2011, May 30). Religious bloc targets Ruddock's electorate. Retrieved October 30, 2014, from http://www.theaustralian.com.au/national-affairs/religious-bloc-targetsruddocks-electorate/story-fn59niix-1226065199677

Kerry, J. (1996, September 10). Defence of Marriage Act - Third Reading. Congressional Record, 142(123), S10106-10108.

Kildea, P., \& Williams, G. (2010). Reworking Australia's referendum machinery. Alternative Law Journal, 35(1), 22-26.

Kiwi Party. (2008). Policies. Retrieved July 22, 2014, from http://ndhadeliver.natlib.govt.nz/ArcAggregator/arcView/frameView/IE625819/http:// thekiwiparty.org.nz/web/

Klingerman, N., \& May, K. (1994). For Better or for Worse, in Sickness and in Health, until Death Do Us Part: A Look at Same-Sex Marriage in Hawaii. University of Hawai ' $i$ Law Review, 16, 447-493.

Krupinski, J. (1974). Demographic Data on Marriage and Family. In J. Krupinski \& A. Stoller (Eds.), The Family in Australia: Social, Demographic and Psychological Aspects (pp. 5-17). Rushcutter's Bay, NSW: Pergamon Press (Australia) Ltd.

Kyd, W. (1998, May 6). De Facto Relationships (Property) Bill, Matrimonial Property Amendment Bill: Second Readings. In New Zealand Parliamentary Debates. $\begin{array}{llll}\text { Retrieved } & \text { September } & 3, & 2014,\end{array}$ http://www.vdig.net/hansard/content.jsp?id=62622

La Corte, R. (2009, January 28). Lawmakers announce "everything but marriage" bill. $\begin{array}{llll}\text { Retrieved } & \text { September } & 1, & \text { 2014, }\end{array}$ http://seattletimes.com/html/localnews/2008678540_apwaxgrdomesticpartnerships2n dldwritethru.html 


\section{3}

Landa, D. P. (1984, October 17). De Facto Relationships Bills. In Hansard - Legislative Assembly (NSW) (48th Parliament) (pp. 1999-2011). Parliament of New South Wales.

Landman, T. (2008). Issues and Methods in Comparative Politics: An Introduction (3rd ed.). Oxford: Routledge.

Lautenberg, F. R. (1996, August 1). Personal Responsibility and Work Opportunity Reconciliation Act of 1996 - Conference Report. Congressional Record, 142(116), S9323-S9325.

Lavers, M. K. (2013, January 8). National Stonewall Democrats curtails operations.

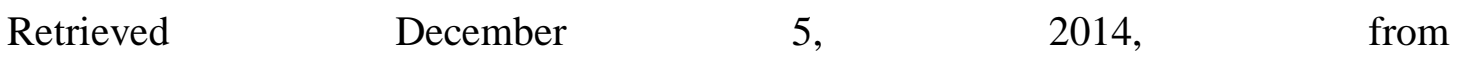
http://www.washingtonblade.com/2013/01/08/national-stonewall-democrats-curtailsoperations/

Leaver, K. (2014, January 23). Nice try, Prime Minister. But I see through your latest family scheme. Retrieved September 8, 2014, from http://www.mamamia.com.au/australianpolitics/tony-abbott-marriage-counselling-vouchers/

Leiter, R. A. (2008). National survey of state laws. Detroit: Thomson Gale.

Le Strat, Y., Dubertret, C., \& Le Foll, B. (2011). Child Marriage in the United States and Its Association With Mental Health in Women. PEDIATRICS, 128(3), 524-530. doi:10.1542/peds.2011-0961

Levin, S. M. (2000, July 20). Conference Report on H.R. 4810, Marriage Tax Relief Reconciliation Act of 2000. Congressional Record, 146(95), H6612.

Lewis, J. (1992). Gender and the Development of Welfare Regimes. Journal of European Social Policy, 2, 159-173. 
LGBT Equality Caucus. (2014). History. Retrieved December 5, 2014, from http://lgbtpolis.house.gov/history

Liberal-National Coalition. (2004, October 6). Australian Women - Opportunities for Life. $\begin{array}{lll}\text { Liberal-National } & \text { Coalition. } & \text { Retrieved }\end{array}$ http://pandora.nla.gov.au/pan/22107/200410080000/www.liberal.org.au/2004_policy/Australian_Women__Opportunities_for_Life_merged.pdf

Lipka, M. (2013, September 13). What surveys say about worship attendance - and why some stay home. Retrieved November 2, 2014, from http://www.pewresearch.org/fact-tank/2013/09/13/what-surveys-say-about-worshipattendance-and-why-some-stay-home/

Logie, J. (2013, September 19). Third Readings. In New Zealand Parliamentary Debates (Vol. 693, pp. 13567-13569).

Lott, T. (1996, September 10). Defence of Marriage Act - Third Reading. Congressional Record, 142(123), S10100-10101.

LPA. (2010). Federal Constitution. Liberal Party of Australia. Retrieved from https://lpawebstatic.s3.amazonaws.com/ccd/2010\%20Liberal\%20Party\%20of\%20Australia\%20Fed eral\%20Constitution.pdf

LPA. (2012). Constitution and Rules. The Liberal Party of Australia (Western Australian Division) Incorporated. Retrieved from https://www.wa.liberal.org.au/sites/www.wa.liberal.org.au/files/constitution_0.pdf

Lugg, C. L. (2007). Christian right. In G. L. Anderson \& K. G. Herr (Eds.), Encyclopedia of Activism and Social Justice (Vol. 1, pp. 324-327). Thousand Oaks, CA: SAGE Reference. 


\section{5}

Maag, E., \& Carasso, A. (2014). What is the Earned Income Tax Credit? Retrieved August 25, 2014, from http://www.taxpolicycenter.org/briefing-book/keyelements/family/eitc.cfm

Mahoney, J. (2000). Path Dependence in Historical Sociology. Theory and Society, 29(4), $507-548$.

Maley, J. (2013, August 31). Listen up, children, it pays to keep families together. Retrieved September 8, 2014, from http://www.smh.com.au/federal-politics/politicalopinion/listen-up-children-it-pays-to-keep-families-together-20130830-2svxn.html

Maley, J., \& Bright, D. (2013, August 28). No discrimination in Coalition's relationship vouchers. Retrieved October 14, 2014, from http://www.smh.com.au/federalpolitics/federal-election-2013/no-discrimination-in-coalitions-relationship-vouchers20130828-2spok.html

Manzie, D. (1991, August 13). De Facto Relationships Bill (Serial 42) - Second reading. In NT Parliamentary Record (Vol. 3, pp. 1057-1060). Retrieved from http://notes.nt.gov.au/lant/hansard/HANSARD6.NSF/0044d01ca7b2aec748255fcd002 4659c/412e18590c7329016925729c001b5628?OpenDocument

Marriage Equality. (2013). Who we are. Retrieved December 8, 2014, from http://www.marriageequality.co.nz/who-we-are.html

Mayer, W. G. (2001). Primary Elections. In N. J. Smelser \& P. B. Baltes (Eds.), International encyclopedia of the social \& behavioral sciences (1st ed, pp. 12011-12014). Amsterdam ; New York: Elsevier.

McCarthy, J. (2014, May 21). Same-Sex Marriage Support Reaches New High at 55\%. Retrieved September 11, 2014, from http://www.gallup.com/poll/169640/sexmarriage-support-reaches-new-high.aspx 
Melleuish, G. (2010). Religion and Politics in Australia. Political Theology, 11(6), 909-927. doi:10.1558/poth.v11i6.909

Merriman, S. A. (2007). Common law marriage. In Religion and the Law in America: An Encyclopedia of Personal Belief and Public Policy (p. 183). Santa Barbara, CA: ABC-CLIO. $\quad$ Retrieved from http://ebooks.abcclio.com/print.aspx?isbn=9781851098644\&id=AMRELA1E. 122

Michigan Legislative Council. (2014). Michigan Law Revision Commission. Retrieved December 1, 2014 , from http://council.legislature.mi.gov/CouncilAdministrator/MLRC

Milesi-Ferretti, G. M., Perotti, R., \& Rostagno, M. (2002). Electoral Systems and Public Spending. The Quarterly Journal of Economics, 117(2), 609-657. doi:10.2307/2696437

Miller, T. (2013). Faith on the Hill: The Religious Composition of the 113th Congress. Retrieved November 2, 2014, from http://www.pewforum.org/2012/11/16/faith-onthe-hill-the-religious-composition-of-the-113th-congress/

Ministry of Justice. (2012). Family Court review: regulatory impact statement (Regulatory impact statement). Wellington: Ministry of Justice. Retrieved from http://www.treasury.govt.nz/publications/informationreleases/ris/pdfs/ris-justice-jfcraug12-v2.pdf

Ministry of Justice. (2014). Family Dispute Resolution - a mediation service: Helping you reach agreement on parenting arrangements. Ministry of Justice. Retrieved from http://www.justice.govt.nz/family-justice/about-us/documents/publications/brochureand-pamphlets/pdf/moj0508-family-dispute-resolution.pdf 
Ministry of Social Development. (2004). New Zealand Families Today: A Briefing for the Families Commission. Wellington: Ministry of Social Development.

Morris, C. (2004). Improving Our Democracy or a Fraud on the Community? A Closer Look at New Zealand's Citizens Initiated Referenda Act 1993. Statute Law Review, 25(2), 116-135. doi:10.1093/slr/25.2.116

Morrison, S. J. (2008, August 28). Family Law Amendment (De Facto Financial Matters and Other Matters) Bill 2008 - Second Reading. In Cth. Parliamentary Debates, House of Representatives (Vol. 10, pp. 6512-6517).

Moseley Braun, C. E. (1996, August 1). Personal Responsibility and Work Opportunity Reconciliation Act of 1996 - Conference Report. Congressional Record, 142(116), S9363-S9363.

Moser, P. (1999). The impact of legislative institutions on public policy: a survey. European Journal of Political Economy, 15(1), 1-33. doi:10.1016/S0176-2680(98)00038-X

Murphy, D. (2004, October 15). Politics is next to godliness. Retrieved October 29, 2014, from http://www.smh.com.au/articles/2004/10/14/1097607367891.html

Murray, M. L. (Kim). (2010, August). John Howard: A Study in Policy Consistency (Thesis submitted for the degree of Doctor of Philosophy in Politics). University of Adelaide, $\begin{array}{lll}\text { Adelaide. } & \text { Retrieved }\end{array}$ http://digital.library.adelaide.edu.au/dspace/bitstream/2440/70068/1/02whole.pdf

Myers, N. R. (2010). God at the Grassroots: A Political Analysis of State-Level Christian Right and Pro-Family Organizations in American Public Schooling. Political Theology, 11(2), 271-286. doi:10.1558/poth.v11i2.271

Nagourney, A. (2012, February 7). California Ban on Gay Marriage Is Struck Down. $\begin{array}{llll}\text { Retrieved } & \text { September } & 10, & 2014,\end{array}$ 


\section{8}

http://www.nytimes.com/2012/02/08/us/marriage-ban-violates-constitution-courtrules.html?_r=0

National Healthy Marriage Resource Center. (2010). Covenant Marriage: A Fact Sheet. VA: National Healthy Marriage Resource Center. Retrieved from http://www.healthymarriageinfo.org/download.aspx?id=329

NCHS. (1974). Summary Report: Final Marriage Statistics, 1970 (No. 23-2 Supplement 1). Rockville, MD: US Department of Health, Education, and Welfare. Retrieved from http://www.cdc.gov/nchs/data/mvsr/supp/mv23_02s1acc.pdf

NCHS. (1983a). Advance Report of Final Divorce Statistics, 1980 (No. 32-3 Supplement). Hyattsville, MD: US Department of Health, Education, and Welfare. Retrieved from http://www.cdc.gov/nchs/data/mvsr/supp/mv32_03s.pdf

NCHS. (1983b). Advance Report of Final Marriage Statistics, 1980 (No. 32-5 Supplement). Hyattsville, MD: US Department of Health, Education, and Welfare. Retrieved from http://www.cdc.gov/nchs/data/mvsr/supp/mv32_05s.pdf

NCWNZ. (2009, February 3). Submission to the Inland Revenue Department on "An Income-splitting tax credit for families with children." NCWNZ. Retrieved from https://web.archive.org/web/20100514032240/http://ncwnz.org.nz/assets/Uploads/S10 .01-Income-Splitting.pdf

Neumann, S. K. (2008, August 28). Family Law Amendment (De Facto Financial Matters and Other Matters) Bill 2008 - Second Reading. In Cth. Parliamentary Debates, House of Representatives (Vol. 10, pp. 6525-6528). Commonwealth of Australia.

New Zealand First. (2008). Policy 2008: Protect and Save Your New Zealand. New Zealand First. Retrieved from http://ndhadeliver.natlib.govt.nz/ArcAggregator//arcView/resource/IE620796//http:// 


\section{9}

www.winstonpeters.com/wp-content/uploads/2008/10/new-zealand-first-2008-

policy.doc

New Zealand Parliament. (2009, June 18). Members' bill ballot. Retrieved November 3, 2014, from http://www.parliament.nz/ennz/features/49NZPHomeNews180620091/members-bill-ballot

New Zealand Parliament. (2012). Making a Submission to a Parliamentary Select Committee. Office of the Clerk of the House of Representatives. Retrieved from http://www.parliament.nz/resource/ennz/00CLOOCMakingSubmission1/263c1047d1e4d16913fb0c51b6692ca95631ee12

NJLRC. (2007). Final Report relating relating to Married Women's Property Acts. Newark, NJ: NJLRC.

NJLRC. (2011). Final Report relating relating to Equitable Distribution and the Elective Spousal Share. Newark, NJ: NJLRC.

Nock, S. L., Wright, J. D., \& Sanchez, L. (1999). America's divorce problem. Society, 36(4), 43-52. doi:10.1007/s12115-999-1039-z

Northwest Justice Project. (2010). Washington Property Law for Unmarried Couples Who Are Separating. Northwest Justice Project. Retrieved from http://www.washingtonlawhelp.org/files/C9D2EA3F-0350-D9AF-ACAE-

BF37E9BC9FFA/attachments/3923394D-B818-E41D-A66D-

6DBEED485A5D/2783213913EN.pdf

NPA. (2013). Federal Constitution. NPA. Retrieved from http://www.nationals.org.au/Portals/0/2013/Constitution/NPA\%20Federal\%20Constit ution\%20JUNE\%202013.pdf 
NSWLRC. (2013). What we do. Retrieved December 1, 2014, from http://www.lawreform.justice.nsw.gov.au/lrc/lrc_whatwedo.html

NWPC. (2014a). About Us. Retrieved November 3, 2014, from http://www.nwpc.org/aboutus NWPC. (2014b). Statistics. Retrieved November 5, 2014, from http://www.nwpc.org/statistics

NZEC. (2011). Official Count Results -- Successful Candidates. Retrieved November 5, 2014, from http://electionresults.govt.nz/electionresults_2011/successfulcand.html

NZEC. (2014). Enrolment Statistics by Electorate. Retrieved July 22, 2014, from http://www.elections.org.nz/research-statistics/enrolment-statistics-electorate

NZLC. (1997). Succession Law, A Succession (Adjustment) Act: Modernising the law on sharing property after death (No. 39). Wellington: Law Commission (NZ).

NZLC. (2014). About the Commission. Retrieved December 1, 2014, from http://www.lawcom.govt.nz/about

NZLP. (1987). The Next Three Years: Labour's Plan for the Future. NZLP.

NZLP. (2014). Constitution and Rules. NZLP. Retrieved from http://www.elections.org.nz/sites/default/files/parties/rules/Labour\%20Party\%20Cons titution\%20and\%20Rules.pdf

NZNP. (1993). Manifesto '93: Stepping out on the Path to 2010. Wellington: NZNP.

NZNP. (1996). The Plan for Progress: The Best is Yet to Come. Wellington: NZNP.

NZNP. (2013, September). Constitution and Rules of the New Zealand National Party. NZNP. Retrieved from http://www.elections.org.nz/sites/default/files/National_party_rules_0.pdf 
NZRL. (2000). Rainbow Labor. Retrieved December 5, 2014, from https://web.archive.org/web/20000517040407/http://www.rainbowlabour.org.nz/defa ult.asp

NZRL. (2007). Campaigns. Retrieved December 5, 2014, from https://web.archive.org/web/20071204194907/http://www.rainbowlabour.org.nz/camp aigns.htm

O’Connor, J. S., Orloff, A. S., \& Shaver, S. (1999). States, Markets, Families: Gender, Liberalism and Social Policy in Australia, Canada, Great Britain and the United States. Cambridge; New York, NY; Melbourne: Cambridge University Press.

Office of Family Assistance. (2014a). Healthy Marriage. Retrieved August 29, 2014, from http://www.acf.hhs.gov/programs/ofa/programs/healthy-marriage/healthy-marriage

Office of Family Assistance. (2014b). Responsible Fatherhood. Retrieved August 29, 2014, from http://www.acf.hhs.gov/programs/ofa/programs/healthy-marriage/responsiblefatherhood

Office of House Bill Analysis. (1999, April 15). Bill Analysis: C. S. H. B. 2442. Retrieved from http://www.capitol.state.tx.us/tlodocs/76R/analysis/html/HB02442H.htm

Office of Regulatory Services. (2013). Civil Partnerships. Retrieved September 7, 2014, from http://www.ors.act.gov.au/community/civil_partnerships

Oldham, J. T. (2008). Changes in the Economic Consequences of Divorces, 1958-2008. Family Law Quarterly, 42(3), 419-447.

Orellana, S. (2010). How Electoral Systems Can Influence Policy Innovation: Orellana: How Electoral Systems Can Influence Policy Innovation. Policy Studies Journal, 38(4), 613-628. doi:10.1111/j.1541-0072.2010.00376.x 
Orloff, A. S. (1996). Gender in the Welfare State. Annual Review of Sociology, 22, 51-78.

Orloff, A. S. (2009). Gendering the Comparative Analysis of Welfare States: An Unfinished Agenda. Sociological Theory, 27(3), 317-343.

Packham, B. (2011, December 3). ALP platform changes to support gay marriage. Retrieved May 21, 2014, from http://www.theaustralian.com.au/archive/national-affairs/alpplatform-changes-to-support-gay-marriage/story-fnba0rxe-1226212916021

Parliament of Australia. (2014a). Opportunities for private Members. Retrieved November 3, 2014 from http://www.aph.gov.au/ /media/05\%20About\%20Parliament/57\%20Education\%20R esources/571\%20Infosheets/PDF/is06.pdf

Parliament of Australia. (2014b). Senators and Members. Retrieved November 5, 2014, from http://www.aph.gov.au/Senators_and_Members

Pate, C. (1998). Covenant Marriage. Retrieved October 21, 2014, from https://web.archive.org/web/19991010071630/http://cwfa.org/library/family/1998-0612_cov-marriage.shtml

Pear, R., \& Kirkpatrick, D. D. (2004, January 14). Bush Plans \$1.5 Billion Drive For Promotion of Marriage. Retrieved September 11, 2014, from http://www.nytimes.com/2004/01/14/us/bush-plans-1.5-billion-drive-for-promotionof-marriage.html

Pedersen, H. H. (2012). Policy-seeking parties in multiparty systems: Influence or purity? Party Politics, 18(3), 297-314. doi:10.1177/1354068810382940

Penberth, D., \& Andrews, K. (2014, April 15). Relationship Assistance, Age Pension, DSP. Retrieved April 28, 2014, from http://kevinandrews.dss.gov.au/transcripts/77 
Perrett, G. D. (2008, August 28). Family Law Amendment (De Facto Financial Matters and Other Matters) Bill 2008 - Second Reading. In Cth. Parliamentary Debates, House of Representatives (Vol. 10, pp. 6517-6521).

Peters, B. G. (1999). Institutional theory in political science: the new institutionalism. London; New York: Pinter.

Peters, B. G. (2008). Institutional theory: problems and prospects. In J. Pierre, B. G. Peters, \& G. Stoker (Eds.), Debating institutionalism (pp. 1-21). Manchester; New York: Manchester University Press; Palgrave Macmillan.

Peters, W. (2013, March 13). Marriage (Definition of Marriage) Amendment Bill: Second Reading. In New Zealand Parliamentary Debates (Vol. 688, pp. 8531-8533).

Pew Research Center. (2010). The Decline of Marriage And Rise of New Families. Pew Research Center.

Picot, G. (2014). Party Systems and Social Policy: A Historical Comparison of Italy and Germany. West European Politics, 37(1), 138-158. doi:10.1080/01402382.2013.801577

Pierson, P. (2000). Increasing Returns, Path Dependency, and the Study of Politics. The American Political Science Review, 94(2), 251-267.

Pinello, D. R. (2006). America's Struggle for Same-Sex Marriage. Cambridge: Cambridge $\begin{array}{lll}\text { University } & \text { Press. } & \text { Retrieved }\end{array}$ http://ebooks.cambridge.org/ref/id/CBO9780511606663

Preston, D. A. (1997). The Compulsory Retirement Savings Scheme Referendum of 1997. Social Policy Journal of New Zealand, 9. 
Price, L. R. S. (1994, November 9). Family Law Reform Bill 1994 [No. 2] - Second Reading. In Cth. Parliamentary Debates, House of Representatives (Vol. 197, pp. 2887-2890).

Pryce, D. D. (2000, July 20). Conference Report on H.R. 4810, Marriage Tax Relief Reconciliation Act of 2000. Congressional Record, 146(95), H6606-H6607.

QLDLRC. (1992). De Facto Relationships - Issues Paper (No. 40). North Quay (Qld): $\begin{array}{lll}\text { QLDLRC. } & \text { Retrieved } & \text { from }\end{array}$ http://www.austlii.edu.au/au/other/lawreform/NSWLRCIP/1981/1.html

Rainbow Labor QLD. (2014). About. Retrieved December 5, 2014, from http://qld.rainbowlabor.org.au/about\#.VIEJxjGUdqU

Reynolds, T. M. (2001, May 25). Waiving points of order against Conference Report on H.R. 1836, Economic Growth and Tax Relief Reconciliation Act of 2001. Congressional Record, 147(74), H2824-H2825.

Richburg, K. B. (2009, April 7). Vermont Legislature Legalizes Same-Sex Marriage. Retrieved September 11, 2014, from http://www.washingtonpost.com/wpdyn/content/article/2009/04/07/AR2009040701663.html

Rinker, K. A. (2010, March 17). Covenant Marriage ... FAILS! Retrieved August 5, 2014, from http://www.kansasfreepress.com/2010/03/covenant-marriagefails.html

RNC. (2014). The Rules of the Republican Party as adopted by the 2012 Republican National Convention. RNC.

Robson, M. (2001, March 29). Third Readings: Property (Relationships) Amendment Bill etc. In New Zealand Parliamentary Debates (Vol. 591, pp. 8628-8629).

Roxon, N. (2004, June 24). Marriage Amendment Bill, Second Reading. In Cth. Parliamentary Debates, House of Representatives (Vol. 11, pp. 31460-31462). 
Ruddock, P. M. (2004, June 24). Marriage Amendment Bill, Second Reading. In Cth. Parliamentary Debates, House of Representatives (Vol. 11, pp. 31459-31460).

Ruddock, P. M. (2005, June 22). Family Law Amendment Bill, Second Reading. In Cth. Parliamentary Debates, House of Representatives (Vol. 12, pp. 125-127).

Ruru, J. (2005). Indigenous Peoples and Family Law: Issues in Aotearoa/New Zealand. International Journal of Law, Policy and the Family, 19(3), 327-345. doi:10.1093/lawfam/ebi026

Ryall, T. (2001, March 29). Third Readings: Property (Relationships) Amendment Bill etc. In New Zealand Parliamentary Debates (Vol. 591, pp. 8626-8628).

Sackville, R., Gressier, D., \& Cass, B. (1981). De Facto Relationships - Issues Paper (No. 1). NSWLRC. Retrieved from http://www.austlii.edu.au/au/other/lawreform/NSWLRCIP/1981/1.html

Sassler, S., \& Miller, A. J. (2011). Class Differences in Cohabitation Processes. Family Relations, 60(2), 163-177. doi:10.1111/j.1741-3729.2010.00640.x

Schmidt, V. A. (2009). Comparative Institutional Analysis. In T. Landman \& N. Robinson (Eds.), The SAGE Handbook of Comparative Politics (pp. 125-144). London: SAGE Publications Ltd.

Schnauer, P. (1998, May 6). De Facto Relationships (Property) Bill, Matrimonial Property Amendment Bill: Second Readings. In New Zealand Parliamentary Debates. $\begin{array}{llll}\text { Retrieved } & \text { September } & 3, & \text { 2014, }\end{array}$ http://www.vdig.net/hansard/content.jsp?id=62625

Schultz, D., \& Vile, J. R. (Eds.). (2005). Congressional Investigations. In The Encyclopedia of Civil Liberties in America (Vol. 1, pp. 213-216). Armonk, NY: Sharpe Reference. Retrieved from 
http://go.galegroup.com/ps/i.do?id=GALE\%7CCX2652900158\&v=2.1\&u=vuw\&it=r $\& p=G V R L \& s w=w \& a s i d=c 7994 d 2814 c b c 3 d d 55 c 01 f 98 d c 568 \mathrm{a} 10$

Scott, L. (2001, March 29). Third Readings: Property (Relationships) Amendment Bill etc. In New Zealand Parliamentary Debates (Vol. 591, pp. 8631-8633).

Sheldon, J. (1999, December 9). Property Law Amendment Bill. In Hansard - Legislative Assembly (QLD) (49th Parliament) (pp. 6268-6270). Queensland Parliament.

Shipley, J. (1998, February 24). Questions for Oral Answer : Discrimination - Legislation. In New Zealand Parliamentary Debates (p. 6699). Retrieved from http://www.vdig.net/hansard/archive.jsp?y=1998\&m=02\&d=24\&o=16\&p=16

Shipley, J. (2000, November 21). Property (Relationships) Amendment Bill (In Committee). In New Zealand Parliamentary Debates (pp. 6706-6708).

Simmons, C. W. (1998). State Grounds for Divorce: A Brief History. California Research Bureau, California State Library. $\quad$ Retrieved from http://www.library.ca.gov/crb/98/04/stateground.pdf

Simpson, S. (2013, September 19). Third Readings. In New Zealand Parliamentary Debates (Vol. 693, pp. 13564-13565).

Smith, M. A. (2010). Religion, Divorce, and the Missing Culture War in America. Political Science Quarterly, 125(1), 57-85.

Smith, N. (2004, June 24). Relationships (Statutory References) Bill: First Reading. In New Zealand Parliamentary Debates (Vol. 618, pp. 13953-13595).

Springborg, L. (1999, December 9). Property Law Amendment Bill - Second Reading. In Legislative Assembly Record of Proceedings (pp. 6259-6265). Brisbane: Queensland 
Parliament.

Retrieved

from

http://www.parliament.qld.gov.au/documents/hansard/1999/991209ha.pdf

State of Hawai'i Department of Health. (2010). Report to the Twenty-Sixth Legislature in compliance with Hawai 'i Revised Statutes $\$ 321-1.3$. State of Hawai'i Department of Health.

Retrieved

from

http://co.doh.hawaii.gov/sites/LegRpt/2011/Reports/1/FY\%202011\%20DV\%20and\% 20SA\%20Special\%20Fund\%20Report\%202010-10-12\%20Final\%20(2).pdf

Statistics NZ. (2001). Marriage and divorce in New Zealand. Statistics NZ. Retrieved from http://www.stats.govt.nz/ /media/Statistics/browse-categories/people-andcommunities/marriages-civil-divorce/marriage-and-divorce/marriage-and-divorce-innz.pdf

Statistics NZ. (2013). Partnership status in current relationship and ethnic group by age group and sex... 2001, 2006, and 2013 Census. Statistics NZ. Retrieved from http://nzdotstat.stats.govt.nz/wbos/Index.aspx?DataSetCode=TABLECODE8011

Statistics NZ. (2014a). Civil Unions and Marriages: June 2014 quarter (provisional) - tables. $\begin{array}{llll}\text { Retrieved } & \text { August } & \text { 14, } & \text { fold, }\end{array}$ http://www.stats.govt.nz/browse_for_stats/people_and_communities/marriages-civilunions-and-divorces/CivilUnionsAndMarriages_HOTPJun14qtr.aspx

Statistics NZ. (2014b). Table: Crude marriage rate, December years (total population) (Annual-Dec). $\quad$ Retrieved $\quad$ November $\quad 18, \quad 2014, \quad$ from http://www.stats.govt.nz/infoshare/ViewTable.aspx?pxID=b50bde50-18b8-49c6a3d5-8d483051d731

Statistics NZ. (2014c). Table: Divorce rate (total population) (Annual-Dec). Retrieved November

20 , 2014 , from 
http://www.stats.govt.nz/infoshare/ViewTable.aspx?pxID=04f45206-40e6-4eb6-8f4b70b71ee3be68

Statistics NZ. (2014d). Table: Marriages by age and previous marital status (Annual-Dec). $\begin{array}{llll}\text { Retrieved } \quad \text { November } & \text { 19, } & \text { 2014, }\end{array}$ http://www.stats.govt.nz/infoshare/ViewTable.aspx?pxID=9190c250-8104-48f79572-246def2dc79f

Strach, P. (2007). All in the Family: The Private Roots of American Public Policy. Stanford: Stanford University Press.

Strongman, S. (2014, September 22). Labour down to 12 women in caucus - National. $\begin{array}{llll}\text { Retrieved } \quad \text { December } & 2, & \text { from }\end{array}$ http://www.nzherald.co.nz/nz/news/article.cfm?c_id=1\&objectid=11329006

Strow, C. W., \& Strow, B. K. (2006). A history of divorce and remarriage in the United States. Humanomics, 22(4), 239-257. doi:10.1108/08288660610710755

Student Legal Service. (n.d.). Civil Unions in Illinois. University of Illinois. Retrieved from http://www.odos.illinois.edu/sls/brochureads/downloads/civilunionsinillinois.pdf

Stutzman, R. (2014, August 21). Judge tosses Florida's same-sex marriage ban. Retrieved September 10, 2014, from http://www.orlandosentinel.com/news/politics/os-gaymarriage-ban-florida-federal-judge-20140821,0,7274389.story

Sweet, R. L. (2005). A History of Service: The Washington State Uniform Legislation Commission. The Washington State Uniform Legislation Commission. Retrieved from http://ulc.wa.gov/HistoryOfService.pdf

Texas Health and Human Services Commission. (n.d.). Frequently Asked Questions. Retrieved August 5, 2014, from http://www.twogetherintexas.com/UI/Faq.aspx 
The Economist. (2008a, October 30). Proposition 8: Showdown. Retrieved September 10, 2014 , from http://www.economist.com/node/12522924?zid=318\&ah=ac379c09c1c3fb67e0e8fd1 $964 d 5247 f$

The Economist. (2008b, November 5). Proposition 8 passes. Retrieved September 10, 2014, from http://search.proquest.com/docview/895941638?pq-origsite=summon

The Humanist Society. (2013). A Handbook for Celebrants (10th ed.). The Humanist Society. Retrieved from http://humanist-society.org/wpcontent/uploads/2013/08/20130806_Celebrant_Handbook.pdf

The White House. (2012). Promoting Responsible Fatherhood. Washington, DC: The White $\begin{array}{lll}\text { House. } & \text { Retrieved } & \text { from }\end{array}$ http://www.whitehouse.gov/sites/default/files/docs/fatherhood_report_6.13.12_final.p df

Titmuss, R. M. (1974). Social Policy: An Introduction. London: George Allen and Unwin.

Toland, B. (2004, April 18). Senate proposal would abolish common-law marriages in Pa. Retrieved September 11, 2014, from http://www.postgazette.com/frontpage/2004/04/18/Senate-proposal-would-abolish-common-lawmarriages-in-Pa/stories/200404180198

Tolley, A. (2001, March 29). Third Readings: Property (Relationships) Amendment Bill etc. In New Zealand Parliamentary Debates (Vol. 591, pp. 8629-8631).

Traiman, L. (2008, July 1). A Brief History of Domestic Partnerships. Retrieved September 1, 2014, from http://www.glreview.org/article/article-635/

Tulsa County District Court. (2014). Family Court Resources. Retrieved August 21, 2014, from http://www.tulsacountydistrictcourt.org/resources.html 
Turei, M. (2004, June 24). Relationships (Statutory References) Bill: First Reading. In New Zealand Parliamentary Debates (Vol. 618, pp. 13957-13958).

Uniform Law Commission. (2014). Marriage and Divorce Act, Model. Retrieved November 16 , 2014 from http://uniformlaws.org/Act.aspx ?title=Marriage\%20and\%20Divorce\%20Act,\%20Mo del

University of Vermont. (2014). Coping with Separation and Divorce. Retrieved August 20, 2014, from http://www.uvm.edu/extension/family/cope/

Unsworth, B. J. (1984, October 30). De Facto Relationships Bills. In Hansard - Legislative Council (NSW) (48th Parliament) (pp. 2691-2695). Parliament of New South Wales.

USBLS. (2013). Women in the Labor Force: A Databook (No. 1040). USBLS. Retrieved from http://www.bls.gov/cps/wlf-databook-2012.pdf

US Census Bureau. (2013). Median Age at First Marriage, Population 15 to 54 years, 2013 American Community Survey 1-Year Estimates. US Census Bureau. Retrieved from http://factfinder2.census.gov/faces/tableservices/jsf/pages/productview.xhtml?pid=AC S_13_1YR_B12007\&prodType=table

Van Acker, E. (2008). Governments and Marriage Education Policy: Perspectives from the UK, Australia and the US. Houndsmills; New York: Palgrave Macmillan.

Vermont Freedom to Marry. (n.d.). Vermont Freedom to Marry: FAQ for Couples Who Want to Marry, or Who Are Joined in Marriage or Civil Union. Retrieved October 6, 2014, from http://www.vtfreetomarry.org/faq-for-couples-who-want-to-marry.html

Vermont Freedom to Marry. (2012, May 1). Vermont drops residency requirements for dissolving Vermont civil unions/marriages. Retrieved August 21, 2014, from 
http://www.vtfreetomarry.org/2012/04/vermont-drops-residency-requirements-fordissolving-vermont-civil-unionsmarriages.html

Vermont Judiciary. (2007). Mediation for Parents in Family Court: Separation, Divorce, Parentage, Dissolution of Civil Union, Blended Families, Post-Divorce. Vermont $\begin{array}{lll}\text { Judiciary. } & \text { Retrieved } & \text { from }\end{array}$ https://www.vermontjudiciary.org/GTC/Family/SharedDocuments/FamilyCrtMediati onProgram.pdf

Vernon, B. (2000, February 29). Matrimonial Property Amendment Bill. In New Zealand Parliamentary Debates (pp. 833-834). Retrieved from http://www.vdig.net/hansard/content.jsp?id=76126

Ver Steegh, N. (2008). Family Court Reform and ADR: Shifting Values and Expectations Transform the Divorce Process. Family Law Quarterly, 42(3), 659-671.

Walby, S. (2009). Gender and the Financial Crisis. Lancaster: Lancaster University. Retrieved from http://www.lancaster.ac.uk/fass/doc_library/sociology/Gender_and_financial_crisis_S ylvia_Walby.pdf

Wallace, J. E. (2005). The Afterlife of the Meretricious Relationship Doctrine: Applying the Doctrine Post Mortem. Seattle University Law Review, 29(1), 243-274.

Wall, L. (2013, March 13). Marriage (Definition of Marriage) Amendment Bill: Second Reading. In New Zealand Parliamentary Debates (Vol. 688, pp. 8523-8525).

Warhurst, J. (2006). Religion in 21st Century Australian National Politics (No. 46). Canberra: Parliament of Australia. Retrieved from http://www.aph.gov.au/About_Parliament/Senate/Research_and_Education/ / /link.a spx?_id=EF9C91705EC24F04B6E8D1ECC120DBD8\&_z=z 


\section{2}

Washington Secretary of State. (2014, March 15). Notice regarding same sex marriage and domestic partnerships. Retrieved September 1, 2014, from http://www.sos.wa.gov/corps/domesticpartnerships/Notice-regarding-same-sexmarriage-and-domestic-partnerships.aspx

Weller, G. C. (2000, July 20). Conference Report on H.R. 4810, Marriage Tax Relief Reconciliation Act of 2000. Congressional Record: Proceedings and Debates of the 106th Congress, Second Session, 146(95), H6607-H6608.

Weston, R. E., Qu, L., \& AIFS. (2013). Working out relationships. Melbourne, Vic.: AIFS.

Weston, R., Qu, L., \& Hayes, A. (2012). From Form to Function. In P. Noller \& G. C. Karantzas (Eds.), The Wiley-Blackwell Handbook of Couples and Family Relationships (pp. 11-24). Malden, MA; Oxford; Chichester: Blackwell Publishing Ltd.

Whitehouse, G. (2004). Women's Policy: Special Interests or Mainstream? In A. Fenna (Ed.), Australian public policy (2nd ed., pp. 361-387). Frenchs Forest, N.S.W.: Pearson Education Australia.

Wilensky, H. L. (1975). The Welfare State and Equality: Structural and Ideological Roots of Public Expenditure. Berkeley; Los Angeles; London: University of California Press Ltd.

Williams, G., \& Hume, D. (2010). People power: the history and future of the referendum in Australia. Sydney: UNSW Press.

Wilson, M. (2001, March 29). Third Readings: Property (Relationships) Amendment Bill etc. In New Zealand Parliamentary Debates (Vol. 591, pp. 8625-8626).

Wolfinger, N. H. (2005). The Mixed Blessings of No-Fault Divorce. Whittier Journal of Child and Family Advocacy, 4(2), 407-430. 
Women's Policy. (2014). Caucus Accomplishments. Retrieved November 3, 2014, from http://www.womenspolicy.org/our-work/the-womens-caucus/caucusaccomplishments/

Wood, G. (2004). Informal security regimes: the strength of relationships. In I. Gough \& G. Wood (Eds.), Insecurity and Welfare Regimes in Asia, Africa and Latin America: Social Policy in Development Contexts (pp. 49-87). Cambridge: Cambridge University Press.

Yates, D. (2001, March 29). Third Readings: Property (Relationships) Amendment Bill etc. In New Zealand Parliamentary Debates (Vol. 591, pp. 8639-8640).

Young, C. (2014, September 3). Unmasking the Conservative Party? Retrieved November 11, 2014, from http://www.gaynz.com/articles/publish/31/article_15683.php 